\title{
The Case for Tailoring Patent Awards Based on the Time-to-Market of Inventions
}

\section{Citation}

Benjamin N. Roin, The Case for Tailoring Patent Awards Based on the Time-to-Market of Inventions, 61 UCLA L. Rev. (forthcoming).

\section{Permanent link}

http://nrs.harvard.edu/urn-3:HUL.InstRepos:10612849

\section{Terms of Use}

This article was downloaded from Harvard University's DASH repository, and is made available under the terms and conditions applicable to Open Access Policy Articles, as set forth at http:// nrs.harvard.edu/urn-3:HUL.InstRepos:dash.current.terms-of-use\#OAP

\section{Share Your Story}

The Harvard community has made this article openly available.

Please share how this access benefits you. Submit a story.

Accessibility 


\title{
The Gase for Tailoring Patent awards BASED ON THE TIME-TO-MARKET OF INVENTIONS
}

\author{
Benjamin N. Roin* \\ March 15, 2013
}

\begin{abstract}
One of the hallmarks of our patent system is that it provides a one-size-fits-all reward for innovation. Few deny a uniform 20-year patent term for all inventions provides too much protection for some, and too little for others. But absent a principled and administrable alternative, the uniform patent system has been our best option. We may know which economic determinants are relevant to a socially optimal patent term and which predispose a patent to stifling future innovation. However, we have lacked a reliable way to measure and synthesize that information in a framework that the government could actually use to tailor patent awards. This paper identifies a readily observable, cross-industry indication of the socially optimal amount of patent protection that different technologies deserve. It demonstrates that "time-to-market," or the time taken for an invention to reach the market, provides the foundation for a system of tailoring patents that strikes the correct equilibrium, balancing the benefits of innovation against the social costs of patents, both in the form of monopoly pricing and threats to subsequent innovation.
\end{abstract}

\section{Table of Contents}

I. Introduction 2

II. Minimum Sufficient Patent Awards and the Costs of Uniformity 11

III. Sequential Innovation and the Rising Costs of Uniformity 19

IV. The Missing Framework for Implementing a Tailored Patent System 26

V. Providing a Framework: the Argument for Tailoring Based on Time-to-Market 32

A. Industry Differences in the Average Time-to-Market for New Inventions 33

B. Time-to-Market Strongly Correlates with the Primary Predictors of Optimal Patent Length 40

1. Time-To-Market as a Signal of R\&D Costs, Uncertainty, and Future Revenue Streams $\quad 41$

2. The Option of Adding Imitation Costs into the Equation 46

3. Policy Implications 48

C. Time-to-Market Strongly Correlates with the Predictors of Optimal Patent Length in Models of Sequential Innovation $\quad 53$

1. The Correlation between Product Life Cycle Length and Optimal Patent Length 54

2. Tailoring based on Time-to-Market as a Proxy for Product Life Cycles 60

D. Time-to-Market is Sufficiently Observable to Support a System of Tailored Patent Awards 66

VI. Other Objections to Tailoring Patent Awards

A. The TRIPS Objection $r 1$

VII. Conclusion

B. The Political Economy Objection $\quad 74$

Hieken Assistant Professor of Patent Law, Harvard Law School. 


\section{INTRODUGTION}

One of the defining characteristics of the current patent system is that it applies a uniform set of rules to all inventions, and does not discriminate on the basis of technology or industry. This uniformity is also one of the most problematic aspects of the patent system. There is overwhelming evidence that the costs and benefits of the system greatly vary across industries. ${ }^{1}$ Patents are critical for innovation in some industries, and they appear to be stifling it in others. The government knowingly overlooks these differences when it awards patent rights on inventions. The justification for this oversight is not that the uniform patent laws are optimal, but rather that we lack an administrable system for tailoring patent awards in a manner that would benefit the public. This paper identifies the basis for such a system. Certain types of inventions take much longer to develop than others, and that difference in time-to-market strongly correlates with both the need for patent protection in an industry and the risk that patents will stifle subsequent innovation. The government can use this observable feature of inventions as the foundation for an objective and remarkably accurate system of tailored patent awards.

The patent system protects a wide array of technologies - everything from microbial fuel cells and radiolabeled pharmaceuticals to interactive cat toys and utensil holders for dishwashers. ${ }^{2}$ Patents are essential for motivating investment in $\mathrm{R} \& \mathrm{D}$ in some circumstances. ${ }^{3}$

\footnotetext{
${ }^{1}$ See Asish Arora et al., REDD and the Patent Premium, 26 InT'LJ. Industrial ORG. 1153, 1170 (2008); Knut Blind et al., Motives to Patent: Empirical Evidence from Germany, 35 Res. POL. 655, 661 (2006); Wesley M. Cohen et al., Protecting Their Intellectual Assets: Appropriability Conditions and Why U.S. Manufacturing Firms Patent (or Not), NBER Working Paper 7552 (2000); Federal Trade Commission (FTC), To Promote Innovation: The Proper Balance of Competition and Patent Law And Policy, ch. 3 (2003); Stuart J.H. Graham et al., High-Technology Entrepreneurs and the Patent System: Results of the 2008 Berkeley Patent Survey, 24 BerkeLEy TECH. L.J. 1255 (2009); Richard C. Levin et al., Appropriating the Returns from Industrial Research and Development, 1987 BROOKINGS PAPERS ON ECONOMIC ACTIVITY 783 (1987); Edwin Mansfield et al., Imitation Costs and Patents: An Empirical Study, 91 ECON. J. 907 (1981); STEPHEN Merrill ET AL., EDS., A PATENT System FOr The $21^{\text {st }}$ Century 35 (2004).

2 See Diamond v. Chakrabarty, 447 U.S. 303, 309 (1980) (noting that "anything under the sun that is made by man" is eligible for patent protection).

3 See FTC, supra note 1, ch. 3 (discussing the importance of patent protection in the pharmaceutical and biotechnology industries for motivating R\&D investments, while noting that patents appear to have mixed effects on
} 
However, they also inevitably limit the public's access to new inventions on the market through monopoly pricing. In an ideal patent system, firms would be given the least amount of patent protection necessary to call forth their inventions. It is obvious that some inventions require far more protection than others, but the patent laws largely ignore these differences. ${ }^{4}$ The government applies a uniform set of rules to determine whether inventions are patentable,$^{5}$ and it awards all inventions a 20 -year term of protection. ${ }^{6}$ This one-size-fits-all approach to promoting innovation provides excessive monopoly protection for many new inventions, while offering insufficient incentives for the development of others.

Scholars and policymakers have long recognized that uniform patent laws cannot provide the optimal incentives for innovation, ${ }^{7}$ but it is now clear that the social costs of this one-size-fitsall system are much greater than was once imagined. Innovation is a cumulative and additive phenomenon. ${ }^{8}$ Researchers are constantly building upon one another's inventions to create newer and better ones, and each step forward in technology generates knowledge spillovers that

R\&D in computer hardware and semiconductors, and perhaps negative effects on innovation in the software industry); Levin et al., supra note 1; Mansfield et al., supra note 1.

4 See Clarisa Long, Our Uniform Patent System, 55 FED. LAWYER 44 (2008).

${ }^{5}$ With very few exceptions, the patent system relies on facially neutral standards to determine whether inventions are patentable. See Long, supra note 4. There is enough ambiguity in these standards for courts to apply slightly different legal tests to different types of inventions. See Dan L. Burk \& Mark A. Lemley, Policy Levers in Patent Law, 89 VA. L. REV. 1575 (2003). However, judicial tailoring of this sort is tightly circumscribed by the technology-neutral statutes that govern patent law.

6 See 35 U.S.C. $\S 154($ a)(2). Technically speaking, the patent term is 20 years minus the time it takes for the PTO to grant the patent, since the "patent term" does not really begin until the patent issues and can be enforced. See Paul M. Janicke, A Need for Clearer Language about Patent Law, 11 J. Marshall REV. InTELL. ProP. L. 457, 465-67 (2012). Moreover, the patent term is not entirely uniform, since firms can receive patent-term extensions when they lost patent life due to certain types of regulatory delays. See 35 U.S.C. $\S 154($ b) (authorizing the PTO to grant patent-term extensions for applications that are held up during prosecution due to PTO delays or that take longer than 3 years to issue - subject to a number of limitations); 35 U.S.C. $§ 156$ (authorizing the PTO to grant patent-term extensions on inventions subject to premarket regulatory review that delays their commercialization).

${ }^{7}$ See Walton Hamilton, Patents and Free Enterprise, U.S. Senate, 76 ${ }^{\text {th }}$ Cong. 3d Sess., Temporary National Economic Committee, Monograph No. 31, at 157 (1941); C. Michael White, Why A Seventeen Year Patent?, 38 J. PAT. OfF. SoG'Y 839, 842-45 (1956).

8 See Suzanne Scotchmer, Standing on the Shoulders of Giants, 5 J. ECON. PERSPECTIVES 29 (1991). 
facilitate further technological advances. ${ }^{9}$ In an environment where innovation begets innovation, the patent system not only restricts public access to inventions through monopoly pricing, it may actually impede future technological progress by making it harder for other firms to build upon earlier discoveries. ${ }^{10}$ Conversely, when the patent system fails to call forth a new invention by offering too little protection, the public loses not just that one invention, but also all future advances that would have come from it. Providing enough patent protection to motive innovation is critical, therefore, but providing too much protection will tend to stifle innovation.

The drawbacks of relying on a uniform patent system became painfully apparent during the legislative debates leading up to the Leahy-Smith America Invents Act of $2011^{11}$ - the first major U.S. patent reform legislation in almost 60 years. The impetus for this bill came from the high-tech industries (i.e., software, semiconductors, and other computer hardware), where the relationship between patents and innovation appears to be "deeply dysfunctional." 12 High-tech firms usually report that they would develop most of their inventions without patents, and that

\footnotetext{
9 See William J. Baumol, The Free-Market innovation Machine: Analyzing the Growth Miracle of Capitalism 11-12 (2002); Brett M. Frischmann \& Mark A. Lemley, Spillovers, 107 Colum. L. Rev. 257, 268-269 (2007); Elhanan Helpman, The Mystery of Economic GrowTH 42-46 (2004); Joel Mokyr, The Contribution of Economic History to the Study of Innovation and Technical Change: 1750-1914, in 1 HANDBOOK OF THE ECONOMICS OF INNOVATION 14 (Brownyn H. Hall \& Nathan Rosenberg, eds. 2010).
}

10 See Suzanne Scotchmer, Innovation And Incentives 127-157 (2004) (reviewing the literature on cumulative innovation).

${ }^{11}$ Pub. L. No. 112-29, 125 Stat. 284 (2011).

${ }^{12}$ L. Gordon Crovitz, Google, Motorola and the Patent Wars, Wall St. J., Aug. 22, 2011 ; see also James E. Bessen, A Generation of Software Patents, Boston Univ. School of Law, Law and Economics Research Paper No. 11-31 (2011); Colleen V. Chien, Reforming Software Patents, 50 Houston L. Rev. 325, 350-90 (2013); Eric Goldman, Fixing Software Patents, Santa Clara Law Digital Commons (1/1/2013); Iain M. Cockburn \& Megan J. MacGarvie, Entry and Patenting in the Software Industry, 57 MgmT. SCI. 915 (2011); Eloise Gratton, Should Patent Protection Be Considered for Software-Related Innovations?, 7 COMP. L. REv. \& TECH. J. 223, 250 (2003); Brian Kahan, Agenda for Reform: Patent Reform for a Digital Economy, Computer and Communications Industry Association (2006); Peter S. Menell, The Challenge of Reforming Intellectual Property Protection for Computer Software, 94 COLum. L. REv. 2644, 2645-46 (1994); Mark Aaron Paley, Article: A Model Software Petite Patent Act, 12 Computer \& High Tech. L.J. 301, 306 (1996); Mark H. Webbink, A New Paradigm for Intellectual Property Rights in Software, 2005 Duke L. \& Tech. Rev. 12, 28 (2005); David A. Wheeler, Eliminate Software Patents (2011), at http://www.dwheeler.com/essays/software-patents.html (containing links to numerous articles that are critical of software patents written by academics, venture capitalists, entrepreneurs and industry executives). 
the government is granting unnecessary and excessive patent monopolies that stifle innovation. ${ }^{13}$

These firms lobbied Congress for numerous reforms that would help mitigate these problems by making it easier to invalidate and harder to enforce patents. ${ }^{14}$ Not every industry was experiencing these same issues with the patent system, however. In the pharmaceutical and biotechnology industries (and perhaps a few other sectors), patents are widely viewed as critical for motivating private sector $\mathrm{R} \& \mathrm{D},{ }^{15}$ and there are fewer complaints about patents inhibiting follow-on innovation. ${ }^{16}$ Many scholars believe that substantially weakening patent protection for drugs and biotechnology would have disastrous consequences for public health. ${ }^{17}$ Not surprisingly, the firms in these industries fought tooth and nail to block most of the reforms advocated by high-tech firms. ${ }^{18}$ After seven years of intense lobbying, very few of the high-tech

\footnotetext{
${ }^{13}$ See FTC, supra note 1, at ch. 3, 30-56.

14 See Jay P. Kesan \& Andres A. Gallo, The Political Economy of the Patent System, 87 N. Garolina L. Rev. 1341 (2009); Joe Matal, A Guide to the Legislative History of the America Invents Act: Part I of II, 21 FED. CIR. B.J. 435 (2012).

${ }^{15}$ Patents are probably most effective at spurring innovation in the pharmaceutical industry, although they appear to have important effects in several others, including biotechnology, agrochemicals, medical devices, clean energy, and certain types of genetically modified crops. See Douglas J. Cumming \& Jeffrey G. Macintosh, The Determinants of RED Expenditures: A Study of the Canadian Biotechnology Industry, 17 REv. INDUSTRIAL ORG. 357, 364, 366-68 (2000); Bronwyn H. Hall \& Dietmar Harhoff, Recent Research on the Economics of Patents, NBER Working Paper 17773, 15 (Jan. 2011), at http://www.nber.org/tmp/84437-w17773.pdf; Gaynor Hartnell, Innovation of Agrochemicals: Regulation and Patent Protection, 25 RES. POL. 379, 387 (1996); Lynn K. Mytelka \& Grant Boyle, Making Choices About Hydrogen: Transport Issues for Developing Countries, International Development Research Centre, United Nations 38 (2008); David E. Schimmelpfennig et al., The Impact of Seed Industry Concentration on Innovation: A Study of US Biotech Market Leaders, 30 AGRICULTURAL ECON. 157 (2004) (finding that patents significantly increase R\&D spending related to genetically modified soybeans, although it is possible that patents are inhibiting R\&D spending on other crops (like corn and cotton) where there are other barriers to imitation that make patents less important).
}

16 See Hall \& Harhoff, supra note 15, at 15; MerRILL ET AL., supra note 1; FTC, supra note 1, at ch. 3. There are plenty of concerns about biotechnology patents stifling downstream innovation. See Michael A. Heller \& Rebecca S. Eisenberg, Can Patents Deter Innovation? The Anticommons in Biomedical Research, 280 SCI. 698 (1998); Clarisa Long, Patents and Cumulative Innovation, 2 WASH. U.J.L. \& POL'Y 229, 246 (2000); Arti Kaur Rai, Regulating Scientific Research: Intellectual Property Rights and the Norms of Science, 94 Nw. U.L. REv. 77, 120-135 (1999). Relative to the high-tech industries, however, it is easier for biotechnology companies to navigate the IP landscape in their fields, and the innovation-stifling effects of these patents are probably less significant. See MerRILl ET AL., supra note 1; FTC, supra note 1 , at ch. 3 .

17 See infra notes and text accompanying notes 209-219.

${ }^{18}$ See Kesan \& Gallo, supra note 14. 
industries' desired reforms made it into the final legislation, ${ }^{19}$ and the ongoing "patent crisis" there continues unabated.

The legislative backstory to the America Invents Act is only the most recent example of where the commitment to uniformity blocked patent reforms that are desperately needed in one industry because they would be detrimental to the interests of another. ${ }^{20}$ An obvious solution to this dilemma would be for Congress or the courts to implement the desired patent reforms only in the industries that need them. This approach would allow the government to curtail excessive patent grants in one field without diminishing patent protection in the areas where it is important for innovation.

There is a long history of resistance to differentiated patent awards in the U.S, ${ }^{21}$ but a growing number of legal scholars and economists are now calling for a more tailored approach to awarding patents. ${ }^{22}$ The uniform 20 -year patent term is perhaps the most obvious candidate for

19 See Zach Carter, The Spoilsmen: How Congress Corrupted Patent Reform (2011) at http://www.huffingtonpost.com/ 2011/08/04/patent-reform-congress_n_906278.html?view=print; Charles Duhigg \& Steve Lohr, The Patent, Used as a Sword, N.Y. Times, Oct. 7, 2012 (noting that "lobbyists from high-tech corporations and the pharmaceutical industry ... push[ed] conflicting proposals," which "paralyzed Congress's ability to make real changes, lawmakers and lobbyists say," and that the America Invents Act ultimately "achieved mostly administrative fixes").

20 See Chien, supra note 12, at 347-348 (discussing the railroad patent crisis and agrarian design patent crisis of the late 1800s); Robert P. Merges, The Trouble with Trolls: Innovation, Rent-Seeking, and Patent Law Reform, 24 BERKELEY TECH. L.J. 1583, 1594-96 (2009) (noting the automobile industry's trouble with patents in the early twentieth century).

${ }^{21}$ MerRill ET AL., supra note 1 , at 84.

22 See Michael Abramowicz, Orphan Business Models: Toward a New Form of Intellectual Property, 124 HARV. L. REV. 1362, 1406-07 (2011); Michael J. Burstein, Rules for Patents, 52 WM. \& MARY L. REV. 1747 (2011); JAMES BESSEN \& Michael J. Meurer, Patent Failure: How Judges, Bureaucrats, and Lawyers Put InNOvation at Risk (2008); Dan Burk \& Mark A. Lemley, The Patent Crisis and How the Courts can Solve It (2009); Daniel R. Cahoy, An Incrementalist Approach to Patent Reform Policy, 9 N.Y.U.J. LegIS. \& PuB. PoL'y 587 (2006); Michael W. Carroll, One for All: The Problem of Uniformity Cost in Intellectual Property Law, 55 AM. U. L. REV. 845 (2006); William Fisher, The Disaggregation of Intellectual Property: How the Laws of Intellectual Property Have Grown-and Grown Apart, HARV. L. Bull., Summer 2004, at 24, 29-31; Eric E. Johnson, Calibrating Patent Lifetimes, 22 SANTA CLARA COMPUTER AND High Tech. L.J. 269 (2006); Amir H. Khoury, Differential Patent Terms and the Commercial Capacity of Innovation, 18 Tex. Intell. Prop. L.J. 373 (2010); Jonathan S. Masur, Regulating Patents, 2010 SuP. CT. Rev. 275, 321-26 (2010); Peter S. Menell, A Method for Reforming the Patent System, 13 Mich. Telecomm. TeCH. L. REV. 487, 493-95 (2007); Peter S. Menell \& Michael J. Meurer, Notice Failure and Notice Externalities, J. LEG. ANALYSIS (forthcoming 2013); Craig Allen Nard \& John F. Duffy, Rethinking Patent Law's Uniformity Principle, 101 Nw. U.L. REV. 1619 (2007); Frank Partnoy, Finance and Patent Length 12-17 (2001) 12-17, U. San Diego Law \& Econ. Research Paper No. 19, available at http//ssrn.com/abstract=285144; Richard A. Posner, Why There are Too Many Patents in America, THE ATLANTIC, July 
reform. ${ }^{23}$ It is difficult to imagine that a 20 -year monopoly provides the optimal incentives for the development of both artificial-heart technology and the slide-to-unlock software for smartphones. Indeed, a number of commentators advocate shortening the patent term for software as a solution to the current patent crisis in that industry. ${ }^{24}$ Nevertheless, a large contingent of patent scholars remain staunchly opposed to any departure from uniform the patent laws, including selective changes to the patent term. ${ }^{25}$

The primary objection to tailoring patent awards is that we lack a principled and administrable framework for the government to use when determining which inventions should receive more protection than others. ${ }^{26}$ The economic theory of optimal patent length is

12, 2012; Joshua D. Sarnoff, The Patent System and Climate Change, 16 VA. J.L. \& TECH. 301 (2011); F.M. Scherer, Nordhaus' Theory of Optimal Patent Life: A Geometric Reinterpretation, 62 AM. Econ. Rev. 422 (1972); Steven ShavelL, Foundations OF ECONOMIC ANALYSIS OF LAW 154 (2004); White, supra note 7, at 842-45. Other scholars have argued for tailoring through policies outside of the patent system, particular in the pharmaceutical and biotechnology industries. See Arti K. Rai, Building a Better Innovation System: Combining Facially Neutral Patent Standards with Therapeutic Regulation, 45 Hous. L. Rev. 1037 (2008); Benjamin N. Roin, Unpatentable Drugs and the Standards of Patentability, 87 TEX. L. REV. 503 (2009).

${ }^{23}$ Several scholars have proposed tailoring the patent term. See Abramowicz, supra note 22; Cahoy, supra note 22; Hamilton, supra note 7; Johnson, supra note 22; Khoury, supra note 22; Menell, supra note 22; Partnoy, supra note 22; Posner, supra note 22; Scherer, supra note 22; SHAVELL, supra note 22; White, supra note 7.

24 See Defend Innovation, Electronic Frontier Foundation, at https://defendinnovation.org/proposal/shortenpatent-term; James Gleick, Patently Absurd, N.Y. Times, Mar. 12, 2000 (Magazine), at 44; Paley, supra note 12, at 306; Webbink, supra note 12, at 28. A few prescient scholars advocated a shorter patent term for software before the crisis. Peter S. Menell, Tailoring Legal Protection for Computer Software, 39 STAN. L. REv. 1329, 1365 (1987); Menell, supra note 12; Pamela Samuelson et al., A Manifesto Concerning the Legal Protection of Computer Programs, 94 Colum. L. Rev. 2308, 2408 (1994). There is also some support for this idea within industry. See Jeff Bezos, Bezos and O'Reilly Spearhead Call for Patent Reform: An Open Letter from Jeff Bezos on the Subject of Patents, Mar. 9, 2000, at http://oreilly.com/news/amazon_patents.html ("[B] usiness method and software patents should have a much shorter lifespan than the current 17 years - I would propose 3 to 5 years.").

${ }^{25}$ See Richard A. Epstein, The Disintegration of Intellectual Property? A Classical Liberal Response to a Premature Obituary, 62 Stan. L. Rev. 455 (2010); AdAM B. JaFFe \& Josh LeRner, InNOVATION AND ITS Discontents: How OuR Broken Patent System Is Endangering InNovation and Progress, and What To Do About It 203-05 (2004); Long, supra note 4, at 47-49; William D. Nordhaus, The Optimal Life of a Patent: Reply, 62 AM. Econ. Rev. 428, 430 (1972); Jae Hun Park, Patents and Industry Standards 162-63 (2010); Qin Shi, Patent System Meets New Sciences: Is the Law Responsive to Changing Technologies and Industries?, 61 N.Y.U. ANNUAL SURVEY OF AM. L. 317 (2005); R. Polk Wagner, (Mostly) Against Exceptionalism, in Perspectives on Properties of the Human Genome Project 367 (F. Scott Kieff ed., 2003); cf. F. Scott Kieff \& Henry E. Smith, How Not to Invent a Patent Crisis, in Reacting to the Spending Spree: Policy Changes we Can Afford 63 (Terry L. Anderson \& Richard Sousa eds. 2009) (objecting to tailoring proposals policies that would arguably lead to more uncertainty over the availability, scope and enforceability of patent protection).

${ }^{26}$ See JAFFE \& LERNER, supra note 25, at 203-04; Long, supra note 4, at 49; PARK, supra note 25, 162-63. 
complicated, ${ }^{27}$ and applying that theory to a particular field of technology is notoriously difficult. ${ }^{28}$ Proponents of tailoring have identified a long list of economic factors the government would need to consider when determining the appropriate duration and strength of patent protection in an industry. Many of these factors are hard to assess, and the sheer number of them would make the inquiry unpredictable, unwieldy, and vulnerable to manipulation. Even if the government were all but certain that the patent system is providing too much or too little protection in an industry, past attempts to correct this type of problem through technologyspecific rules have proven disappointingly ineffective. ${ }^{29}$ The dividing lines between technologies are highly permeable and tend to shift rapidly as technology changes. Firms can often draft their patent claims to select into categories offering greater protection, and technology-specific rules frequently become obsolete shortly after becoming law. Unless the government can better link these rules to less manipulatable economic characteristics of inventions, technology-specific patent laws may be an exercise in futility.

This paper provides a foundation for an administrable system of tailoring patent awards that would avoid these problems. The government can use the amount of time it takes to develop inventions to determine which industries and technological fields should receive more or less

\footnotetext{
27 See, e.g., Ian Ayers \& Paul Klemperer, Limiting Patentees’ Market Power Without Reducing Innovation Incentives: The Perverse Benefits of Uncertainty and Non-Injunctive Remedies, 97 MICH. L. REV. 985 (1999); John F. Duffy, A Minimum Optimal Patent Term (2003), available at http://ssrn.com/abstract=354282; Nancy T. Gallini, Patent Policy and Costly Imitation, 23 RAND J. Econ. 52 (1992); Richard Gilbert \& Carl Shapiro, Optimal Patent Length and Breadth, 21 RAND J. ECON. 106, 111 (1990); Morton I. Kamien \& Nancy L. Schwartz, Patent Life and R \& D Rivalry, 64 AM. ECON. REV. 183 (1974); Louis Kaplow, The Patent-Antitrust Intersection: A Reappraisal, 97 HARV. L. REV. 1813 (1984); WILLIAM M. Landes \& Richard A. Posner, The Economia Structure of Intellectual Property LaW (2003); W. Nordhaus, Invention, Growth and Welfare 76-88 (1969); Ted O'Donoghue et al., Patent Breadth, Patent Life, and the Pace of Technological Progress, 7 J. Econ. \& MGmT. Strategy 1 (1998); Scherer, supra note 22.

28 See David S. Abrams, Did TRIPS Spur Innovation? An Analysis of Patent Duration and Incentives to Innovate, 157 U. PENN. L. REv. 1613, 1615 (2009); Ian Ayers \& Gideon Parchomovsky, Tradable Patent Rights, 60 STAN. L. REV. 863 , 892 (2007) ("Quantitatively tailoring the patent system is a Herculean burden.").

${ }^{29}$ Many of the scholars who advocate tailoring patent awards on the basis of technology are opposed to legal rules that explicitly discriminate along technological lines, and argue instead that courts (or an agency) should use facially neutral legal standards to tailor their patent awards to the needs for patent protection in each industry. See BURK \& LEMLEY, supra note 22; MERRILL ET AL., supra note 1, at 83-85; Rai, supra note 22.
} 
protection relative to others. The crux of the article is the claim that time-to-market is strongly correlated with the optimal patent life of inventions.

First, the paper shows that the time-to-market for inventions bears a close relationship to the amount of patent protection needed to motivate their development. The ideal patent award for an invention is primarily a function of its $R \& D$ costs, the risk of failure in that $R \& D$, the anticipated future revenue streams from the project if it succeeds, and the potential for imitation by rivals. The time-to-market for inventions is a reliable indicia of all four factors. Longer development cycles increase the costs of capital for an R\&D investment while diminishing the value of future revenue streams because of discounting. They are also correlated with higher outof-pocket R\&D costs, greater technological uncertainty, and in most cases, an increased vulnerability to free riding from competitive imitation. Inventions that take longer to reach the market therefore are much more likely to need a lengthy patent term as an incentive for their R\&D, whereas inventions with a shorter time-to-market usually need much less protection.

Second, the paper demonstrates that time-to-market is a strong predictor of the extent to which patents are likely to stifle follow-on innovation. Although patents are supposed to encourage investment in $\mathrm{R} \& \mathrm{D}$, strengthening patent rights can have the opposite effect in industries where earlier innovators would develop their inventions irrespective of those stronger patent rights; where the patents on those earlier inventions often cover many later improvements in the technology; and where transaction costs in licensing are high. The time-to-market for inventions is inversely related to all three. Inventions that reach the market quickly tend to have a short product life cycle, since it takes less time for firms to develop the newer inventions that ultimately replace them on the market. Under conditions of rapid incremental innovation and fast product turnover, patents tend to be much less important than first-mover advantages for motivating investments in R\&D. Those patents are also more likely to read onto several future 
generations of incremental improvements in the technology, which imposes a tax on later innovators. Moreover, the transaction costs in licensing are higher for inventions with short product life cycles because negotiation delays erode a larger portion of their already brief commercial lifespan. The time-to-market for inventions therefore provides a powerful indicator not only to inventions' need for patent protection, but also to whether those patents are likely to impede subsequent innovation.

Since the optimal patent award for inventions in a field strongly correlates with their average time-to-market, which is readily observable, this paper argues that the government should tailor its patent awards on this basis. It presents evidence from a wide range of sources showing that the average time-to-market for inventions varies greatly across industries. In finance, consumer products, software and semiconductors, development cycles are quick and new inventions usually reach the market quickly. Industries on the opposite end of the spectrum include pharmaceuticals, biotechnology, clean energy, and oil and gas drilling, where development times can run from five to 20 years. Tailoring patent awards to reflect these differences could avoid many of the problems that now plague the patent system. Although the paper primarily focuses on tailoring patent protection through variable patent terms, the government could use a variety of other policy levers as well, including the standards of patentability, the scope of patent protection, the stringency of PTO examinations, antitrust rules, government subsidies, or even prizes.

Parts II and III of the paper outline the theoretical case for why tailored patent awards are preferable to a one-size-fits-all system, and set forth the main economic factors relevant to optimal patent length. Part IV describes the primary objection that has been raised against tailoring patent awards. Part V is the heart of the article. It reports figures on the average timeto-market for inventions in a wide range of industries; it shows that time-to-market is strongly 
correlated with optimal patent length; argues that the government should use time-to-market to tailor its patent awards; and provides several examples of where tailoring the patent term based on time-to-market could generate immense benefits for the public. Part VI then discusses and rebuts two other objections to tailoring through technology-specific patent laws - that those laws would violate the TRIPS agreement, and that powerful industry groups would distort the laws to such a degree that they would ultimately harm the public. Part VII concludes.

\section{Minimum Sufficient Patent Awards and the Cost of Uniformity}

The patent system is designed to promote innovation by awarding firms temporary monopoly rights over their inventions. Those awards are costly to the extent that they restrict access to new inventions. In an ideal patent system, firms would receive just enough patent protection to motivate the $\mathrm{R} \& \mathrm{D}$ of their inventions, but no more. It is clear that some inventions need more protection than others to reach the public, and that the importance of patent protection varies by industry. Although scholars and policymakers are aware of these differences, the patent system continues to operate as a one-size-fits-all system of promoting innovation. The uniform patent laws are simultaneously over- and under-inclusive, providing unnecessary and excessive protection against competition in many cases and inadequate protection in others. Within this system of largely indiscriminate patent awards, almost any policy that adjusts the overall strength or availability of patent protection will correct for one of these problems at the expense of the other one. A more tailored system of patent awards is one of the only ways to avoid this costly tradeoff.

Although patents perform a number of different economic functions, the system's primary goal has always been "[t]o promote the Progress of Science and useful Arts," as is proscribed in 
the U.S. Constitution. ${ }^{30}$ The system operates to correct a particular market failure in the incentives for investing in $\mathrm{R} \& \mathrm{D}$ that can arise when it is easier to imitate an invention than to create it. ${ }^{31}$ Not all investments in R\&D are vulnerable to this type of free riding, ${ }^{32}$ but many of them are. ${ }^{33}$ Indeed, firms routinely capitalize on their rivals' R\&D through competitive imitation. ${ }^{34}$ This strategy allows firms to save money on R\&D and marketing, ${ }^{35}$ and to minimize their risk exposure by copying only those inventions that are a technological and commercial success. ${ }^{36}$ The patent system addresses this free-rider deterrent to $\mathrm{R} \& \mathrm{D}$ investment by giving

\begin{abstract}
30 Art. I, sec. 8, cl. 8. The classic economic view also characterizes patents as a tool for promoting innovation. See Fritz Machlup, Subcomm. On Patents, Trademarks \& Copyrights of the S. Comm. On the Judiciary, 85 ${ }^{\mathrm{TH}}$ Cong., An Economic Review of the Patent System 21 (Comm. Print 1958).

${ }^{31}$ See Kenneth J. Arrow, Economic Welfare and the Allocation of Resources for Invention, in THE RATE AND DiRECTION OF InVENTIVE ACTIVITY: ECONOMIC AND SOCial Factors 609, 615 (Richard Nelson ed. 1962).
\end{abstract}

32 See Michele Boldrin \& David K. Levine, Against Intellectual Monopoly 123-146 \& 184 (2008) (acknowledging that competitive markets can result in a failure that undermines the incentives for innovation, but arguing that this problem is much smaller than economists commonly assume).

${ }^{33} \mathrm{~A}$ study by Mansfield et al. of 48 product innovations found that the cost of imitating those innovations, on average, was roughly two-thirds the cost of creating them. See Mansfield et al., supra note 3, at 910. There is tremendous variation in the data, however, since half of the product innovations had imitation costs that were either less than 40 percent or more than 90 percent of the original R\&D costs, suggesting that many inventions are either very difficult or fairly easy to imitate. $I d$. A survey of industrial R\&D executives by Levin et al. also found that imitation is usually less expensive than innovation, but again with significant variation across inventions. See Levin et al., supra note 3 , at 807-812. A survey of industrial R\&D executives at Swiss firms concluded that imitating unpatented inventions costs 40 to 50 percent less than creating them on average. See Najib Harabi, Innovation Versus Imitation: Empirical Evidence from Swiss Firms, MPRA Paper No. 26214 (1991), at http://mpra.ub.unimuenchen.de/26214/.

${ }^{34}$ See Michele Kremen Bolton, Imitation Versus Innovation: Lessons to be Learned from the Fapanese, 21 ORGANIZATIONAL Dynamics 32 (1993); Steven P. SchnaArs, Managing Imitation Strategies: How Later Entrants Seize MARKETS FROM PIONEERS 1 (1994) ("Imitation is not only more abundant than innovation, it is actually a much more prevalent road to business growth and profits."). A survey of 416 firms in 2004 found that $30 \%$ reported pursuing a first-to-market strategy, while over $35 \%$ claimed to pursue a "fast follower" strategy. See Marjorie Adams, PDMA Foundation New Product Development Report Initial Findings: Summary of Responses from 2004 CPAS, PRODUCT Development \& MGMT. Association 27 (2004).

${ }^{35}$ See Gezinus J. Hidding et al., The IT Platform Principle: The First Shall Not Be First, WaLl St. J., Jan. 25, 2010; SCHNAARS, supra note 34 , at 31 .

${ }^{36}$ See Bolton, supra note 34, at 30; SCHNAARs, supra note 34, at 23. Industry surveys indicate that anywhere from 25 to $76 \%$ of $\mathrm{R} \& \mathrm{D}$ projects fail to produce a marketable invention. See Adams, supra note 34; Abbie Griffin, PDMA Research on New Product Development Practices: Updating Trends and Benchmarking Best Practices, 14 J. Product InNovation Mgmt. 429, 447-48 (1997); Henrique Rocha \& Mauricio Delamaro, Project/Product Development Process Critical Success Factors: A Literature Compilation, 2 RES. IN LOGISTICS \& PRODUCTION 274, 275 (2012). Among those R\&D projects that succeed on a technological level, anywhere from 40 to $95 \%$ of the resulting inventions are commercial failures. See Adams, supra note 34; Carmen Nobel, Clay Christensen's Milkshake Marketing, HBS Working Knowledge 1, Feb. 
innovators the exclusive right to make, use and sell their inventions for a limited period of time, allowing them to earn monopoly profits on their inventions. ${ }^{37}$

This protection offered by patents is important for motivating at least some of private industry's R\&D investments. ${ }^{38}$ However, many inventions would reach the public even without these legal barriers to imitation. ${ }^{39}$ It usually takes time for other firms to develop and commercialize their own version of a rival's invention, ${ }^{40}$ which gives the innovator time to recover some or all of its $\mathrm{R} \& \mathrm{D}$ costs. This lead-time sometimes translates into more lasting competitive advantages as well, ${ }^{41}$ especially when the lead-time is substantial, ${ }^{42}$ their head start allows them to stay ahead of rivals by continually improving upon their invention, or there are "switching costs" that deter existing customers from buying the imitations. ${ }^{43}$

14, 2011; Oracle, AGaelerate Product Innovation And Maximize Profitability 10 (2011) at http://www.oracle.com/us/products/applications/agile/agile-product-lifecycle-mgmt-070032.pdf.

3735 U.S.C. $§ 271($ a) (2011).

38 See Arora et al., supra note 1, at 1170; Mansfield et al., supra note 1. Even the harshest critics of the patent system acknowledge (even if only by implication) that the patent system motivates at least some private sector R\&D, although they believe that the number of R\&D projects that would not occur but for the patent system is smaller than the number of projects that do not occur because of the patent system. See, e.g., Michele Boldrin \& David K. Levine, The Case Against Patents, 27 J. ECON. PERSP. 3, 7 (2013).

39 Surveys of industry executives reveal that, in most industries, firms would have developed the vast majority of their patented inventions even without that protection. See Levin et al., supra note 1, at 808-12; Mansfield et al., supra note 1, at 907-10; Edwin Mansfield, Patents and Innovation: An Empirical Study, 32 MGMT SCI. 173 (1986).

40 See Harabi, supra note 33; Levin et al., supra note 1, at 807-12; Mansfield et al., supra note 1, at 910.

${ }^{41}$ See William T. Robinson \& Sungwook Min, Is the First To Market the First To Fail? Empirical Evidence for Industrial Goods Businesses, 39 J. MARKETING RES. 120 (2002). The literature on first-mover advantages suggests that they are heavily contingent upon other factors, including whether the invention is an "appropriable technology," which may depend on whether there is strong patent protection or trade secrecy available. See Marvin B. Lieberman, First Mover Advantages, in Palgrave Encyclopedia of Strategic Management, (forthcoming).

42 See Marvin B. Lieberman \& David B. Montgomery, First-Mover (Dis)Advantages: Retrospective and Link with the ResourceBased View, 19 Strategic Mgmt.J. 1111, 1117-20, 1121 (1998); Luis E. López \& Edward B. Roberts, First-Mover Advantages in Regimes of Weak Appropriability: the Case of Financial Services Innovations, 55 J. BUS. RES. 97, 1004 (2002) (finding that "if subsequent entrants invade the market within short periods of time after the pioneer, pioneering advantages are scant"); Robinson \& Min, supra note 41, at 127.

43 See Marvin B. Lieberman \& David B. Montgomery, First-Mover Advantages, 9 StRATEgiC MGMT. J. 41, 42-43 \& 4647 (1988). 
To the extent that the patent system is effective at promoting innovation by shielding firms from competitive imitation, it serves a critical function in enhancing social welfare. ${ }^{44}$ Inventions are information-based goods that are "nonrivalrous," in that the idea for an invention can be used over and over again by any number of people without diminishing in value, and without anyone needing to repeat the initial investment in $\mathrm{R} \& \mathrm{D}$ that created it. $^{45}$ These features allow for increasing returns to scale on the use of the world's finite supply of labor and capital. ${ }^{46}$ Innovation is therefore the primary driver of long-run economic growth, and thus is responsible for much of the wealth of the modern world. ${ }^{47}$ Most of the funding for R\&D that produces this innovation comes from private industry. ${ }^{48}$ Empirical studies have consistently found that private sector $\mathrm{R} \& \mathrm{D}$ generates tremendous social value on average, ${ }^{49}$ and that the social rate of return

\footnotetext{
${ }^{44}$ Among other benefits, technological progress has allowed people to live increasingly longer and more comfortable lives. See David M. Cutler, Your Money or Your Life: Strong Medicine for America's Healthcare System 1-9 (2004); Richard A. Easterlin, The Worldwide Standard of Living Since 1800, 14 J. Econ. PersPectives 7 , 12 (2000); Joel Mokyr, The Lever of Riches: Technological Greativity and Economic Progress 303 (1990).

${ }^{45}$ See Paul M. Romer, Endogenous Technological Change, 98 J. POL. EcON. S7 1, S74-S75 (1990).

${ }^{46}$ As Paul Romer explains:
}

In a world with physical limits, it is discoveries of big ideas (for example, how to make high-temperature superconductors), together with the discoveries of millions of little ideas (better ways to sew a shirt), that make persistent economic growth possible. Ideas are the instructions that let us combine limited physical resources in arrangements that are ever more valuable.

Paul M. Romer, Two Strategies for Economic Development: Using Ideas and Producing Ideas, in Proceedings OF THE WORLD BANK: ANNuAl CONFERENCE ON DEvelopment Economics 199264 (Lawrence H. Summers \& Shkhar Shah, eds. 1993); see also Charles I. Jones, Growth and Ideas, in 1B HANDBOoK OF ECONOMIC GROwTH 1063, 108889 (Philippe Aghion \& Steven N. Durlauf eds. 2005).

47 The empirical evidence linking economic growth to innovation dates back to Robert Solow's groundbreaking work in the 1950s. See Robert M. Solow, A Contribution to the Theory of Economic Growth, 70 Q.J. ECON. 65 (1956); Robert M. Solow, Technical Change and the Aggregate Production Function, 39 REv. ECON. STATISTics 312 (1957). The claim that innovation drives long-run economic growth is now well established. See Philippe Aghion \& Peter Howitt, Endogenous Growth Theory 11 (1997); W. Brian Arthur, The Nature of Technology: What It Is AND How It Evolves 10 (2009); Baumol, supra note 9, at 13; N. Gregory Mankiw, The Growth of Nations, 1995 Brookings Papers Econ. ACtivity 275, 280 (1995); Richard R. Nelson, The Sources OF ECONOMIC GROWTH 31 (1996).

48 See National Science Foundation (NSF), Division of Science Resources Statistics, National Patterns of RED Resources: 2008 Data Update, 22-23 tbl. 5 (2010).

49 See Congressional Budget Office (CBO), REDD and Productivity Growth: A Background Paper, 23-28 (2005); ZVI Griliches, R\&D, Education, And Productivity: A Retrospective 70 (2000); Bronwyn H. Hall et al., 
from privately funded R\&D is usually far greater than the profits firms earn from their investments. ${ }^{50}$

The patent system also imposes costs on society, however, because it reduces the social value of inventions by restricting access to them. Patents entice firms to invest in R\&D by allowing them to sell their inventions at supra-competitive prices. By their very nature, therefore, patents make it harder for consumers to afford new inventions. This pricing distortion results in deadweight loss, as those consumers who would buy patented inventions at their competitive (but not supra-competitive) prices are pushed out of the market. ${ }^{51}$ The higher prices can also inhibit subsequent advances in patented technologies by limiting the ability of researchers to use and improve upon other firms' inventions. ${ }^{52}$ Offering too much patent protection might even reduce a firm's incentive to continue investing in $\mathrm{R} \& \mathrm{D}$, allowing it to rely on its monopoly rights for a

Measuring the Returns to RङD, in 2 HANDBOOKS IN ECONOMics: ECONOMics OF INNOVATION 1065-1073 (Bronwyn H. Hall \& Nathan Rosenberg eds., 2010) (surveying the economic literature).

50 See CBO, supra note 49, at 9; Zvi Griliches, The Search for REDD Spillovers, 94 Scand. J. ECON. S29, S43 (1992); Brett M. Fischmann \& Mark A. Lemley, Spillovers, 107 Colum. L. Rev. 257, 259-260 n.5 (2007); John M. Golden, Innovation Dynamics, Patents, and Dynamic-Elasticity Tests for the Promotion of Progress, 24 HARV. J.L. \& TECH. 47, 61-63 (2010); Bronwyn H. Hall et al., Measuring the Returns to RED, in 2 HandBOOKS IN EconOMics: Economics OF InNOVATION 1073 (Bronwyn H. Hall \& Nathan Rosenberg eds., 2010); HelPMAN, supra note 9, at 43; Charles I. Jones \& John G. Williams, Measuring the Social Return to RED, 113 Q.J. ECON. 1119, 1134 (1998); R. Polk Wagner, Information Wants to be Free: Intellectual Property and the Mythologies of Control, 103 CoLum. L. REv. 995 (2003).

${ }^{51}$ See Arrow, supra note 31, at 616-17.

52 See Heller \& Eisenberg, supra note 16; Mark A. Lemley, The Economics of Improvement in Intellectual Property Law, 75 TEx. L. REv. 989 (1997); Long, supra note 16; Robert P. Merges \& Richard R. Nelson, On the Complex Economics of Patent Scope, 90 Colum. L. ReV. 839 (1990); Rai, supra note 16, at 120-135; SCOTCHMER, supra note 10, at 127-157. 
competitive advantage instead of spending more on R\&D to stay ahead of its rivals. ${ }^{53}$ Excessive rewards can also cause patent racing. ${ }^{54}$

Given the social costs of patent grants, it is generally believed that patents should be reserved for inventions that otherwise would not reach the public. ${ }^{55}$ The intuition behind this principle is fairly obvious. While patents reduce the social returns from innovation by restricting the public's access to new inventions, it is better for the public to have restricted access to inventions than no access at all. When firms are willing to develop new inventions without the promise of patent protection, the opposite is true - patents impose social costs of monopoly pricing without the corresponding benefit of promoting innovation.

The same principle applies for determining the appropriate amount of protection to award each new invention. The ideal patent term for any given invention is one that is long

53 See Philippe Aghion et al., Competition, Imitation and Growth with Step-by-Step Innovation, 68 REV. ECON. STUD. 467, 468 (2001). These models also suggest that offering too little patent protection in competitive environments can stifle innovation, and there is some empirical evidence to support this conclusion. See Philippe Aghion et al., Patent Rights, Product Market Reforms, and Innovation (2013), at http://scholar.harvard.edu/files/aghion/files/patent_rights.pdf. (finding that "the product market reform that was part of the European Single Market Program in 1992 enhances innovation in industries that are located in countries where patent rights are strong, but not in industries of countries where patent rights are weak," and that "the positive innovation response to the product market reform is more pronounced in industries in which innovators rely more on patenting than in other industries, and in which the scope for deterring entry through patenting is not too large").

54 See Jean Tirole, The Theory of Industrial Organization 399 (1988). Edmund Kitch argues that patents have the opposite effect, however, because they are granted early in R\&D and therefore end the race sooner. See Edmund Kitch, The Nature and Function of the Patent System, 20 J.L. \& ECON. 265, 276-77 (1977). Either way, recent empirical studies indicate that the amount of socially wasteful spending due to R\&D racing is relatively low. See Nicholas Bloom et al., Identifying Technological Spillovers and Product Market Rivalry, working paper, (2012) at http://personal.lse.ac.uk/schanker/bsvr_finalcopy.pdf; Paul A. David \& Bronwyn H. Hall, Heart of Darkness: Modeling Public-Private Funding Interactions Inside the REDD Black Box, 29 RES. POL'Y 1165, 1167-68 (2000); Charles I. Jones \& John C. Williams, Too Much of a Good Thing? The Economics of Investment in RED, 5 J. ECON. GROWTH 65, 66 (2000). These findings suggest that patent racing is a secondary concern, although many legal scholars continue to emphasize the goal of avoiding patent races as a central policy objective. See John F. Duffy, Rethinking the Prospect Theory of Patents, 71 U. CHI. L. REV. 502 (2004); Einer Elhauge, Tying, Bundled Discounts, and the Death of the Single Monopoly Profit Theory, 123 HARV. L. REV. 397, 439-41 (2009); LANDES \& POSNER, supra note 27, at 315-16 \& 327.

55 As Judge Richard Posner once explained, "patents should be granted" when "an invention might not be made (not so soon, anyway) unless the inventor could get a patent," but "[t]he balance tips against protection when the invention is the sort that was likely to be made, and as soon, even if no one could have patented it." Roberts v. Sears, Roebuck \& Co., 723 F.2d 1324, 1345-46 (7th Cir. 1983) (en banc) (Posner, J., concurring in part and dissenting in part); see also Michael Abramowicz \& John F. Duffy, The Inducement Standard of Patentability, 120 YALE L.J. 1590 (2011). 
enough to motivate its development, but no longer. ${ }^{56}$ This Goldilocks rule runs counter to many people's initial instincts, since it is natural to think that firms who develop more valuable inventions should be rewarded with a longer term of protection, ${ }^{57}$ but this view ignores the social costs of that reward. ${ }^{58}$ If an invention needs 20 years of patent protection to reach the public, offering anything less will stifle its development, while offering anything more creates unnecessary deadweight loss (as people are denied access for longer periods) without any corresponding public benefit from increased innovation. Under the traditional law and economics view of patent policy, therefore, the ideal patent length for an invention is usually the shortest possible monopoly period that still provides an adequate incentive for its R\&D and commercialization.

It is clear that some inventions need more protection than others as an incentive for their development, and that the importance of patent protection varies by industry. ${ }^{59}$ To successfully call forth an invention, the patent system must offer enough protection for the inventor to anticipate a profit from investing in its $\mathrm{R} \& \mathrm{D}$. The ideal patent life for an invention is primarily a function of the cost and uncertainty of its $\mathrm{R} \& \mathrm{D}$, the revenue streams it generates once on the

56 See SHAVELL, supra note 22, at 145-46 (defining "the optimal length of property rights" as "the minimum period necessary to generate monopoly profits usually sufficient to cover development costs"). John Duffy has challenged the orthodox view that patents should provide the minimum sufficient term of protection. See Duffy, supra note 27; Duffy, supra note 54, at 475-80. Duffy argues that when the patent term for an invention is more than needed to motivate its development, competing firms will race to secure the profits from the patent by trying to be the first to file their application. Since the patent term runs from the filing date, Duffy contends that these patent races operate as "Demsetzian auctions," where the winner is the firm willing to develop an invention in exchange for the shortest effective patent life. $I d$. at 491. In keeping with the literature on patent racing, Duffy utilizes a "production-function model" of R\&D investing, which assumes that R\&D opportunities are common knowledge, and that firms can always accelerate their R\&D projects by simply devoting more resources to them. These stylized assumptions consciously ignore the role of creativity in $\mathrm{R} \& \mathrm{D}$ and the cumulative nature of innovation. See SCOTCHMER, supra note 10 , at 54 . In reality, firms cannot patent inventions until their employees discover them, which may require creative insights that do not occur on a predictable schedule. Moreover, many inventions are made possible by other recent technological developments in the industry, which individual firms generally cannot control. Given these external constraints on the pace of innovation, there are limits to how early firms can discover and patent most new inventions, even under intense rivalry. It possible that firms could sometimes speed up their research by several months or even a year or two, but if the patent term is too long by five or even ten years, it is unclear that firms could normally accelerate their research to match.

57 See Kaplow, supra note 27, at 1849-54 (discussing several instances where scholars have made this mistake).

58 See id., at 1828.

59 See supra note 1. 
market, and the extent to which rival firms can quickly imitate it in the absence of patent protection. Inventions can differ dramatically from one another along these dimensions. Pharmaceuticals costs hundreds of millions of dollars to develop and involve a high risk of failure ${ }^{60}$ while many mobile phone applications (“apps") involve significantly less risk and cost under a hundred thousand dollars to produce. ${ }^{61}$ It is hard to know the ideal patent length for either type of invention, but it is obvious that the former will require a much longer period of protection than the latter in most cases.

Nonetheless, the patent system primarily operates under a one-size-fits-all framework. Patents run for 20 years from their filing date, ${ }^{62}$ and courts apply (roughly) the same standards of patentability when they award patents and determine their scope. ${ }^{63}$ Shorter or weaker patents would be sufficient for the vast majority of new inventions, ${ }^{64}$ which suggests that the current patent system subjects the public to a great deal of unnecessary deadweight loss. However, there is reason to believe that strengthening the system would call forth some new inventions that might be extremely valuable to society, including in the areas of disease prevention and cleanenergy technology ${ }^{65}$ William Nordhaus was the first scholar to formally model the economic

${ }^{60}$ See Joseph A. DiMasi et al., The Price of Innovation: New Estimates of Drug Development Costs, 22 J. Health Econ. 151, 180-83 (2003).

61 See Carter Thomas, How Much Does It Cost to Develop an App?, Blue Cloud Solutions (Mar. 2011), http://www.bluecloudsolutions.com/blog/cost-develop-app/ (discussing the costs of developing an application (or "app") for an iPhone).

6235 U.S.C. $\S 154(\mathrm{a})(2)$; see supra note 6 (discussing the timing of the patent term and the availability of certain patent-term extensions that compensate firms for some regulatory delays).

${ }^{63}$ See supra note 5.

${ }^{64}$ See Machlup, supra note 30, at 9; Scherer, supra note 22, at 426; White, supra note 7.

${ }^{65}$ See Abramowicz, supra note 22, at 1402-06 (discussing various examples of inventions that would likely require a patent term of longer than 20 years to be developed); Roin, supra note 22 (showing that the patent system fails to provide any protection for previously disclosed compounds with potential therapeutic value that have never been tested in clinical trials or approved by the FDA, and that as a result, they never reach the public); Benjamin N. Roin, Drug Patent Length (2009), at http://www.law.harvard.edu/faculty/faculty-workshops/faculty-workshopsecure/roin.workshop.paper.summer.2009.pdf (arguing that the current patent term is insufficient for drugs that require lengthy clinical trials to demonstrate efficacy, including treatments for early-stage cancer and cancer prevention). 
analysis of patent length when the government must select a single patent term for a heterogeneous group of inventions. ${ }^{66} \mathrm{He}$ described how lengthening the term will lead to more innovation, but also creates additional deadweight loss by extending the patents on all of the inventions that firms would have developed with the shorter patent period. ${ }^{67}$ Although it is theoretically possible to calculate the optimal patent length within the constraints of uniformity, ${ }^{68}$ this patent term would not be the first-best outcome. The public would be better off if the government could identify many of the inventions that need more than 20 years of patent protection and lengthen their patent term, while providing less protection to many of the inventions that will still reach the public with a much shorter term.

\section{Sequential Innovation and the Costs of Uniformity}

The current impetus for patent reform mostly emanates from the high-tech sector, where many commentators believe that patents are too easy to obtain ${ }^{69}$ and provide too much protection to inventors. ${ }^{70}$ These complaints are rarely about shielding consumers from the harms associated with monopoly pricing. They are about unnecessary and excessive patent grants taxing innovative companies and discouraging their R\&D investments. ${ }^{71}$ Using models of sequential innovation (where each new invention is a steppingstone to the next), economists have provided a useful account of how the patent system usually has mixed effects on the incentives for

66 See NORDHAUS, supra note 27, at 70-90.

67 See id.

68 See Kaplow, supra note 27, at 1825; NoRDHAUs, supra note 27, at 76. Some of the subsequent efforts to model optimal patent length incorporate patent racing into the dynamic, although the policy implications of this literature are highly ambiguous. See Peter S. Menell \& Suzanne Scotchmer, Intellectual Property, in 2 HANDBOOK OF LAW \& ECONOMICS 1488-90 (2008).

69 See, e.g., JAFFE \& LERNER, supra note 25.

70 See, e.g., Julie E. Cohen \& Mark A. Lemley, Patent Scope and Innovation in the Software Industry, 89 CAL. L. REV. 1 (2001).

71 See supra note 12. 
R\&D. Patents provide incentives for firms to create valuable new inventions that facilitate later technological advances, but those monopoly rights also impose a tax on subsequent innovators who are building upon those earlier inventions to create better ones. These economic models offer several insights into patent policy that bolster the case for tailoring patent awards and offer guidance for identifying situations where longer patent terms might stifle subsequent innovation.

Although there is nothing new about the idea that patents can discourage innovation, ${ }^{72}$ the classic economic model outlined by Nordhaus does not explain how patents could have this effect. These classic models imagine a world where innovative firms compete against copycat rivals. Increasing the duration or strength of patent protection always spurs additional innovation, but at the expense of increased consumer deadweight loss from monopoly pricing.

Beginning with the work of Suzanne Scotchmer, economists began to adjust these models to depict a world where competition occurs between innovative firms that build upon one another's inventions. ${ }^{73}$ This form of "competitive imitation" has a different dynamic than depicted in Nordhaus' classic model. Although some competitive imitation is merely copycatting, rival firms often try to improve upon the earlier invention when they develop their own versions, ${ }^{74}$ and when they succeed, their inventions may push the original one off the market. The rival firms are free riding off the original innovator's R\&D efforts to some extent, but they are also investing in $\mathrm{R} \& \mathrm{D}$ and creating their own inventions. ${ }^{75}$ These innovations generate their own knowledge spillovers that will likely help other researchers to further improve upon the

\footnotetext{
72 See Machlup, supra note 30, at 10-13.

${ }^{73}$ Scotchmer, supra note 8; see also James Bessen \& Eric Maskin, Sequential Innovation, Patents, and Imitation, 40 RAND J. ECON. 611 (2009); Lemley, supra note 52; Menell \& Scotchmer, supra note 68, at 1501-02 (reviewing the literature); Merges \& Nelson, supra note 52.

74 See Bolton, supra note 34, at 32; SCHNAARS, supra note 34, at 211-26.

75 Although the private returns from R\&D spending are usually much smaller than the social returns, see supra note 50 , there are circumstances where rival firms may spend more on the R\&D of an invention than it is worth to the public because they can profit by stealing business away from their competitors. See TIROLE, supra note 52 , at 399.
} 
technology. ${ }^{76}$ When this competitive imitation occurs too quickly, however, it can undermine the incentives for investing in $\mathrm{R} \& \mathrm{D}$ in the first place, and all of these benefits unravel. ${ }^{77}$ If rivals capture too much market share away from the original innovator before it appropriates enough of the social returns to recoup its investment, the innovator might not create that invention in the first place - leaving nothing for rivals to build upon.

The patent system provides a means of transferring profits from the later generations of innovators to the earlier ones (e.g., through licensing or delaying their entry onto the market). When firms patent their inventions, they usually try to draft the claims to cover not only direct imitations of their invention, but also some of the subsequent improvements that they (or other firms) might make to it. ${ }^{78}$ These forward-reaching patents are a deliberate feature of the system, since the later technological advances made possible by an invention are part of its social value. ${ }^{79}$ A patent on the active ingredient in a new drug applies not only to generics, therefore, but also to newly discovered uses for the drug, new formulations that make it easier to manufacture or administer, and anything else new that involves using the claimed compound. ${ }^{80}$ Although these later discoveries are often patentable inventions in their own right, they are still covered by the initial patent - giving rise to what is known as "blocking patents." 81 Any firm that develops one of the later inventions will be unable to commercialize that technology without paying royalties to

\footnotetext{
76 See Stephen J. Nickell, Competition and Corporate Performance, 4 J. POL. ECON. 724 (1996).

77 See Aghion et al., supra note 53.

${ }^{78}$ For a discussion of the rules controlling the ability of firms to draft broad patent claims covering later-arising improvements in their inventions, see Charles W. Adams, Blocking Patents and the Scope of Claims (2009) at http://www.stanford.edu/dept/law/ipsc/pdf/adams-charles.pdf; Cohen \& Lemley, supra note 70; Christopher A. Cotropia, "After-Arising" Technologies and Tailoring Patent Scope, 61 NYU ANnUAL SURVEy OF AmERICAN LAW 151 (2005); Lemley, supra note 52.

79 See Wagner, supra note 50.

80 See Brenner v. Manson, 383 U.S. 519, 537 (1966) (J. Harlan, dissenting).

${ }^{81}$ See Robert P. Merges, A Brief Note on Blocking Patents and Reverse Equivalents: Biotechnology as an Example, 73 J. PAT. OFF. SOC'Y 878, 878-80 (1991).
} 
the firm that developed the earlier one, and the later innovator might even be barred from the market entirely.

These models of sequential innovation reveal that the patent system will have mixed effects on the incentives for R\&D. ${ }^{82}$ On the one hand, the patent system encourages firms to create inventions that provides a steppingstone to later advances by allowing them to extract licensing fees from those follow-on innovators. In some cases, the original innovators might have been unwilling to create their inventions without the right to appropriate a portion of the value from the later advances they spurred - particularly if the rivals can enter quickly. ${ }^{83}$ On the other hand, these patents are operating as a tax on the technological advances that follow them, potentially discouraging those later developments. ${ }^{84}$ This tax only poses a threat to subsequent innovation in the presence of transaction costs. ${ }^{85}$ Unfortunately, the transaction costs are often high in patent licensing, ${ }^{86}$ mostly because of asymmetric information, ${ }^{87}$ potential hold-up

82 See Scotchmer, supra note 10, at 146-52 (reviewing the literature).

83 See Menell \& Scotchmer, supra note 68, at 1499; O’Donoghue et al., supra note 27; Scotchmer, supra note 8.

${ }^{84}$ See BesSEn \& Meurer, supra note 22; Heller \& Eisenberg, supra note 52, at 700-01; JAFFE \& LERNER, supra note 25; Lemley, supra note 52; Menell \& Scotchmer, supra note 68, at 1477; Merges \& Nelson, supra note 52; Rai, supra note 52 , at $120-135$.

85 See Menell \& Scotchmer, supra note 68, at 1500-01 (discussing the relevance of transaction costs to whether patents stifle subsequent technological advances in an environment of sequential innovation); Henry E. Smith, Intellectual Property as Property: Delineating Entitlements in Information, 116 YALE L. J. 1742 (2007).

86 See Lemley, supra note 52, at 1052-59 (identifying a number of barriers to IP licensing, including asymmetric information, uncertainty about the value of the technology and scope of the IP rights, and that IP licensing usually requires complex legal instruments that makes it costly to negotiate them and monitor performance); Heller \& Eisenberg, supra note 52, at 700-01 (arguing that various transaction costs impede efficient licensing when upstream IP rights are fragmented). The substantial transaction costs involved in patent licensing are sometimes mitigated by the formation of patent pools or practices of widespread industry cross-licensing. See Ronald J. Mann, Do Patents Facilitate Financing in the Software Industry?, 83 TEX. L. REv. 961, 1006-09 (2005) (reporting interview results suggesting that software patents can be important for startup financing).

87 See Nancy T. Gallini, The Economics of Patents: Lessons from Recent U.S. Patent Reform, 16 J. Econ. Perspectives 131, 137 (2002) (discussing the practical barriers to negotiating a license ex ante, i.e., before the subsequent inventor has sunk significant R\&D costs creating the improvement); SCOTCHMER, supra note 10, at 1041-42 (describing how asymmetric information regarding the value of the technology makes patent licensing much more likely to result in failure). 
problems, ${ }^{88}$ and the fact that IP licensing often requires complicated legal arrangements that are difficult (and very expensive) to negotiate. ${ }^{89}$ When the original and subsequent innovators cannot reach a deal, patents may inhibit subsequent advances in the technologies they protect. ${ }^{90}$

Legal scholars sometimes characterize the literature on cumulative (or sequential) innovation as an argument in favor of a shorter patent term or weaker patent rights, ${ }^{91}$ but its policy implications are subtler. The literature indicates that excessive patent grants cause more social harm than previously assumed because they can stifle subsequent technological advances. It also highlight the importance of providing adequate protection to call forth new inventions, however, since each step forward in technology will lead to later advances, and those later

88 See Jerry R. Green \& Suzanne Scotchmer, On the Division of Profit in Sequential Innovation, 26 RAND J. ECON. 20, 21 (1995) (describing the importance of ex ante licensing because of the hold-up problem); Merges \& Nelson, supra note 52, at 865-67 (discussing how the threat of a hold-up problem can discourage firms from attempting to license patents ex post - i.e., after they have invested in R\&D to create the improvement).

89 See Iain M. Cockburn, Is the Market for Technology Working? Obstacles to Licensing Inventions, and Ways to Reduce Them 6-7, Conference on Economics of Technology Policy, Monte Verità (2007), at https://faculty.fuqua.duke.edu/ charlesw/s591/Bocconi-Duke/Bocconi/S2_2008_02_11_MFT/Cockburn__Is_the_Market_for_Technology_Working.pdf (reporting from a survey that IP deals usually require more attention from top management, more costly due diligence, and more challenging negotiations, with $50 \%$ of attempted licensing deals failing to reach an agreement); see also Ashish Arora \& Alfonso Gambardella, Ideas for Rent: An Overview of Markets for Technology, 19 INDUS. \& CORP. CHANGE 775, 787-91 (2010) (noting that industry executives report that there are significant transaction costs in IP licensing stemming from uncertainty over the scope of patent rights, the value of the technology, and the transaction process).

${ }^{90}$ Patents probably facilitate subsequent innovation under certain circumstances, however, such as when firms would otherwise keep their inventions secret, or when there is inadequate patent protection for downstream innovations. See, e.g., John F. Duffy, Intellectual Property Isolationism and the Average Cost Thesis, 83 TEX. L. REV. 1077 (2005); F. Scott Kieff, Coordination, Property, and Intellectual Property: An Unconventional Approach to Anticompetitive Effects and Downstream Access, 56 EMORY L.J. 327 (2006). Patents disclose technical information about inventions to other researchers, which helps with the dissemination of knowledge. See Wesley M. Cohen et al., RED Spillovers, Patents and the Incentives to Innovate in Fapan and the United States, 31 RES. POLICY 1349 (2002); Lisa Larrimore Ouellette, Do Patents Disclose Useful Information, 25 HARV.J.L. \& TECH. 531 (2012). Patents also probably lower the transaction costs of licensing relative to trade secrets. See Arrow, supra note 31, at 615; Robert Mazzoleni \& Richard R. Nelson, Economic Theories about the Benefits and Costs of Patents, 32 J. ECON. Issues 1031, 1038-40 (1998). But see Michael J. Burstein, Exchanging Information Without Intellectual Property, 91 TEx. L. REV. 227 (2012) (arguing that patents are often unnecessary for transactions over information). The available empirical evidence - which is limited - suggests that patents are more likely to hinder later advances in technology when granted on inventions the public would receive anyway. See Fiona Murray et al., Of Mice and Academics: Examining the Effect of Openness on Innovation, NBER Working Paper 14819, March 2009; Heidi Williams, Intellectual Property Rights and Innovation: Evidence from the Human Genome, Aug. 20, 2010, at http://econwww.mit.edu/files/6803.

91 See, e.g., Mark A. Lemley et al., Life After Bilski, 63 StAn. L. Rev. 1315, 1329 \& 1339-41 (2011). 
advances will be lost if no one takes that initial step. These findings bolster the case for tailoring patent awards by showing that errors in either direction stifle innovation.

When the models of sequential innovation are situated within the larger literature on economic growth theory, they suggest that scholars have been underestimating the potential benefits from tailoring patent awards. It is now well established that innovation is the primary driver of long-run economic growth, and therefore is critical for the advancement of social welfare. ${ }^{92}$ The link between innovation and economic growth is in large part due to the positive externalities from R\&D, especially the knowledge spillovers that facilitate subsequent innovation. ${ }^{93}$ When the patent system fails to call forth a new invention by offering too little protection, the public loses not just that one invention, but also all the future advances that would have come from it. ${ }^{94}$ Granting too much protection ensures that the public will receive the initial invention, but it imposes an unnecessary tax on the innovations that might follow, likely slowing or preventing some of those later advances. ${ }^{95}$ Either way, the patent system is stifling the overall rate of technological progress, which will inhibit economic growth. Tailoring is the only way to reduce the incidence of both types of errors.

In addition to highlighting the importance of tailoring, the models of sequential innovation provide guidance for identifying industries where longer patents are more likely to stifle technological progress. Within models of sequential innovation, the social costs of a longer patent term are primarily a function of the degree to which earlier patents read onto later

\footnotetext{
92 See supra note and text accompanying note 47.

${ }^{93} I d$.

94 See Menell \& Scotchmer, supra note 68, at 1499 (“[W]hen innovation is cumulative, the most important social benefit of an innovation may be the boost given to later innovators, and this may make the benefits harder to appropriate."); Wagner, supra note 50.

95 See supra note 84.
} 
inventions, and the transaction costs of licensing. ${ }^{96}$ The benefits of a longer patent term will likely outweigh these social costs only where innovators need that additional protection to motivate their inventions in the first place. ${ }^{97}$

Another implication of these models is that lengthening the current statutory patent term will have little effect on the incentives for innovation in areas where most inventions are obsolete long before their patent expires, ${ }^{98}$ which is probably the norm in many fields. ${ }^{99}$ Any remaining patent life past this point of obsolescence is relatively harmless to the public because there is no longer any demand for the invention. Assuming that firms anticipated their inventions would be obsolete prior to the end of their patent term, the additional life also probably had little effect on the incentives for R\&D. Several prominent patent scholars have therefore concluded that the statutory term is probably "irrelevant" in many circumstances. ${ }^{100}$ The effective patent life for these inventions is determined more by the scope of their patent than the duration of that right.

These insights from the literature on sequential innovation indicate that the patent term should be shorter when (1) innovation is more "cumulative" (i.e., when innovative firms must license a large number of earlier patents to commercialize their inventions), (2) transaction costs are high, and (3) firms can appropriate a significant portion of the social value of their inventions without lengthy patent rights. They also suggest that the patent term is less important as a policy lever in fields where most inventions become obsolete quickly.

\footnotetext{
${ }^{96}$ See Nancy Gallini \& Suzanne Scotchmer, Intellectual Property: When is it the Best Incentive System?, 2 InNOvation POL. \& ECON. 51, 67 (2002).

97 See Menell, supra note 22, at 493-95; Menell \& Scotchmer, supra note 68, at 1502.

98 See Cotropia, supra note 78, at 171-172; Gallini \& Scotchmer, supra note 96, at 66; Merges \& Nelson, supra note 52; O'Donoghue et al., supra note 27, at 2.

${ }^{99}$ Indeed, more than half of all granted patents fall into the public domain at the end of their $11^{\text {th }}$ year because the patentee failed to pay the modest renewal fee necessary to maintain them for the full 20-year term. See USPTO, PERFORMANCE AND ACGOUNTABILITY REPORT: FISGAL YEAR 2012, 73 (2012).

100 See John R. Allison \& Emerson H. Tiller, The Business Method Patent Myth, 18 Berkeley Tech. L.J. 987, 1065-66 (2003); Gallini \& Scotchmer, supra note 96, at 66; O’Donoghue et al., supra note 27, at 2.
} 


\section{The Missing Framework for Implementing a Tailored Patent System}

With a few notable exceptions, the government does not discriminate amongst industries or fields of technology when it awards patents on inventions, ${ }^{101}$ even though that protection is critical for innovation in some industries and may be stifling it in others. ${ }^{102}$ The patent term is the most striking example of the system's commitment to the uniform treatment of inventions. ${ }^{103}$ Congress promises a 20-year monopoly over all patentable inventions despite knowing that most of them would probably be developed under a shorter patent term, ${ }^{104}$ and that some inventions likely will be lost because the 20 -year term is too short. ${ }^{105}$ The drawbacks of this one-size-fits-all system are obvious. Nevertheless, many patent scholars steadfastly oppose allowing the government to tailor patent awards to the needs of each industry. The core argument against tailoring is that the government lacks a principled and reliable legal framework for deciding which inventions should receive more or less protection. Most of the economic factors that are directly relevant to the calculation of optimal patent awards are not observable to the government. Assuming observation is possible, the economic analysis of optimal patent length is still far too complex and multifactorial to be readily applied by the government without substantial risk of arbitrary results or political manipulation. Moreover, technology-specific patent laws are notoriously difficult to implement because the boundaries between technologies

\footnotetext{
101 See supra note 5; infra notes and text accompanying notes 331-350 (discussing some of the technology-specific provisions in the patent statutes).

102 See supra note 1.

103 See Act of March 2, 1861, ch. 88, §§ 16-17, 12 Stat. 246, 249 (1861) (eliminating the discretionary 7-year patent term extension and adopting a uniform 17-year patent term).

104 See MACHLUP, supra note 30, at 9; Menell \& Scotchmer, supra note 68, at ; Scherer, supra note 22, at ; White, supra note 7 . Indeed, more than half of all issued patent expire before the end of their 20 -year term because the patentee fails to pay the rather modest maintenance fees required to preserve them. See USPTO, supra note 99, at 73.

105 See Abramowicz, supra note 22, at 1402-06 (discussing various examples of inventions that would likely require a patent term of longer than 20 years to be developed).
} 
are highly ambiguous and mutable, which makes it hard to categorize inventions properly. Unless the government can resolve the inevitable line-drawing questions based on the relevant economic characteristics of the inventions at issue (as opposed to their technological characteristics), firms will be able to draft their patents to select into categories offering more protection.

It would be much easier to tailor the patent term to individual inventions if the government could reliably observe the primary determinants of their ideal patent length $-\mathrm{R} \& \mathrm{D}$ costs, risk of failure and future revenue streams. Unfortunately, firms do not publicly disclose any of the three key factors required by the classic model. The costs of their R\&D projects, their risk of failure, or the anticipated revenue streams from a successful project are all largely unknown. The government could audit firms to measure their R\&D expenses or the actual net revenues from their inventions, but these inquiries would entail significant administrative costs. ${ }^{106}$ Moreover, the audits themselves might be unreliable due to discretion exercised in allocating overhead costs among a firm's different R\&D projects. ${ }^{107}$ Concerns about administrative burdens and unreliability likely explain why the currently government ignores R\&D costs and anticipated revenues when it awards patents. The third factor - risk of failure in $\mathrm{R} \& \mathrm{D}-$ is one of the considerations under the nonobviousness test. ${ }^{108}$ However, the inherent subjectivity and technologically challenging nature of this inquiry probably makes risk of failure the least

\footnotetext{
106 If the government were to insist that firms maintain documentary support of their R\&D expenses to permit an audit, it would increase the recordkeeping costs associated with R\&D, particularly since firms would now need to keep track of their R\&D expenses as they relate to each of the inventions they produce. See Tom Windram, How To Realize the Benefits of the RED Tax Credit, MANufaCTURING.NeT, July 15, 2008, at http://www.manufacturing.net/ Articles-How-To-Realize-The-Benefits-Of-The-R-D-Tax-Credit.aspx?menuid=242.

107 See Stephen M. Maurer \& Suzanne Scotchmer, Procuring Knowledge, 15 InTELLEGTUAL PROPERTY AND ENTREPREnEURShIP 1, 5 (2004); Joel Slemrod \& Shlomo Yitzhaki, Tax Avoidance, Evasion, and Administration, in 3 HANDBOOK OF PUblia ECONOMICS 1423 (2002).
}

108 See KSR Int'l Co. v. Teleflex Inc., 550 U.S. 398 (2007). 
observable of the three factors. ${ }^{109}$ Indeed, one of the common justifications given for using patents (or prizes) instead of government contracts to finance $\mathrm{R} \& \mathrm{D}$ is that private industry is better situated to evaluate the technological and commercial uncertainty of an R\&D project. ${ }^{110}$

The economic factors relevant for tailoring patent awards under sequential-innovation theory might be even harder to apply on a case-by-case basis. Assuming that the tailoring occurs ex ante, the government would need to speculate about whether the claim language in a patent will read onto future innovations before those innovations exist. Although the PTO may be able to identify patents that overtly cover a wide range of future technological advances, ${ }^{11}$ a more fine-grained analysis is impossible due to the limits of foresight.

Given the government's limited information about the features of inventions that are directly relevant to their optimal patent award, it would be difficult for the government to tailor patent length (or breadth) based on these factors. ${ }^{12}$ An obvious alternative is to link awards to other invention characteristics correlated with the ideal length. Since the costs and benefits of patent protection vary by industry, ${ }^{113}$ numerous scholars advocate the use of industry- and technology-specific rules to tailor patent awards. ${ }^{114}$ Many of these tailoring proposals are directed

109 The PTO and courts continually struggle with the application of the nonobviousness standard. See FTC, supra note 1. Learned Hand once commented that the test for nonobviousness is "as fugitive, impalpable, wayward, and vague a phantom as exits in the whole paraphernalia of legal concepts." Harries v. Air King Products, Co., 183 F.2d 158, 162 (2d Cir. 1950).

110 See Menell \& Scotchmer, supra note 68, at 1477.

111 See O'Reilly v. Morse, 56 U.S. 62 (1854). Several scholars have argued that courts should use section 101 to police the outer-bounds of overly broad patents. See Rebecca S. Eisenberg, Wisdom of the Ages or Dead-Hand Control?' Patentable Subject Matter for Diagnostic Methods After In re Bilski, 3 CASE W. RES. J.L. TECH. \& InTERnET 1 (2012); Mark A. Lemley et al., Life After Bilski, 63 Stan. L. REv. 1315, 1329 \& 1339-41 (2011); Allen K. Yu, Within Subject Matter Eligibility-A Disease and a Cure, 84 SO. CAL. L. REv. 387 (2011). The Supreme Court initially embraced this theory in Mayo Collaborative Services v. Prometheus Laboratories, but ultimately refused to tether its $\S 101$ "law of nature" test to the economic scope of a patent. 566 U.S._(2012).

112 See Abramowicz, supra note 22, at 1394-95.

113 See supra note 1.

114 See supra note 22. 
at software patents, ${ }^{115}$ including calls to abolish them, ${ }^{116}$ shortening their duration, ${ }^{117}$ imposing heightened patentability standards that result in fewer and narrower software patent grants, ${ }^{118}$ or create new defenses to infringement against those patents. ${ }^{119}$

These proposals for industry-specific patent reform are very controversial. ${ }^{120}$ Indeed, many of the scholars who have argued most forcefully that patents are stifling innovation in the high-tech sectors have also argued against any industry- or technology-specific patent rules. ${ }^{121}$ These scholars are not opposed to tailoring patent awards because they believe a uniform patent system is ideal. ${ }^{122}$ Their primary objection to tailoring is that the government lacks a principled and reliable legal framework for deciding which technologies and industries are eligible for greater or lesser monopoly protection through the patent system. As Adam Jaffe and Josh Lerner explain:

In the world of theoretical patent analysis, it is easy to show that the attributes of patent protection should vary depending on the characteristics of the technology. Thus, there appears to be a fundamental theoretical case for differential patents .... The problem with using this theory as a basis for policy, however, is that the technology characteristics that could provide the basis for differential patent treatment are typically abstract and difficult to quantify empirically. ... So while there is a theoretical case for a system that is not

\footnotetext{
115 See Chien, supra note 12, at 350-90 (discussing various reform proposals for software patents); Goldman, supra note 12 , at 7-11 (same).

116 See Pamela Samuelson, Benson Revisited: The Case Against Patent Protection for Algorithms and Other Computer ProgramRelated Inventions, 39 EMORY L.J. 1025 (1990); Wheeler, supra note 12. Many critics of software patents are oppose outright prohibition on the grounds that it would be over-inclusive and that it is very hard to distinguish software patents from patents on other types of inventions that involve software. See BURK \& LEMLEY, supra note 22, at 15758; Cohen \& Lemley, supra note 78; Goldman, supra note 12, at 1-2 \& 5-6. However, other scholars are more optimistic about the ability to enforce a ban on software patents. See BESSEN \& MEURER, supra note 22, at 243-47; Chien, supra note 12, at 353-58. On February 8, 2013, the en banc Federal Circuit heard arguments in CLS Bank v. Alice Corp. about whether "computer-implemented inventions" are eligible for patent protection, and much of the oral arguments was related to line-drawing questions.

117 See supra note 24.

118 See BURK \& LEMLEY, supra note 22; FTC, supra note 1; Kahan, supra note 12.

119 See Bessen \& MeURer, supra note 22, at 251; Cohen \& Lemley, supra note 78.

120 See supra note 25 (citing various opponents to industry-specific tailoring).

121 See JAFFE \& LERnER, supra note 25, at 203-205; PARK, supra note 25, at 162-63;

122 See JAFFE \& LERnER, supra note 25, at 203-205; Long, supra note 4, at 49; Nordhaus, supra note 25, at 430; PARK, supra note 25 , at 162-63.
} 
uniform, there is no theoretical or empirical basis for saying specifically how patent treatment should differ across specific technologies. ${ }^{123}$

The proponents of tailoring have identified a host of economic factors relevant to the inquiry, but not an administrable system for tailoring patent awards based on the need for protection. ${ }^{124}$ For example, Peter Menell highlights twelve factors the government should consider when tailoring patent awards, including: R\&D costs; technological risk; public funding for the research; adequacy of alternative means of appropriating the returns from $R \& D$; value of patent disclosures; cumulativeness of innovation; transaction costs; network effects; clarity of patent scope; due diligence costs related to patent searches; problems related to patent leveraging and misuse; and other abuse problems. ${ }^{125}$ Michael Carroll adds several other considerations to this list, including whether the proposed rules would be administrable, and the political economy issues in their drafting and implementation. ${ }^{126}$ The difficulty lies in synthesizing these many relevant factors - which often point in opposite directions - in a coherent fashion, so that the government's tailoring decisions are not arbitrary or motivated by rent seeking. Of course, the difficulties in measuring many of these factors also remain a concern.

An equally serious objection to technology-specific patent laws is that they are often unwieldy and ineffective. ${ }^{127}$ The dividing lines between technologies are porous and change over time. Many inventions fall within multiple distinct categories of technology, ${ }^{128}$ which makes line-

123 See JAFFE \& LERNER, supra note 25, at 203-204.

${ }^{124}$ For example, Dan Burk and Mark Lemley outline a framework based on a variety of different economic theories of the costs and benefits of patenting, where the government would tailor its awards for each industry based on the economic theories best characterize it. See Burk \& Lemley, supra note 5, at 1675-95.

${ }^{125}$ Menell, supra note 22, at 495 fg. 1.

${ }^{126}$ Michael W. Carroll, One Size Does Note Fit All: A Framework for Tailoring Intellectual Property Rights, 70 OHIO ST. L.J. 1361, 1406-32 (2009).

127 See BURK \& LEMLEY, supra note 22, at 98-99.

128 See PARK, supra note 25, at 162-63 (noting that many inventions are assigned to more than one technological category (IPG code group) on their patent because they cover several technological groupings, and concluding that 
drawing problems inevitable in any system of technology-specific patent laws. Consider, for example, the classification of a brain-computer interface technology, which may be more akin to software, computer hardware, other electronics, medical devices, diagnostics, video game technology, or any other field that is likely to use these inventions. ${ }^{129}$ Line-drawing problems of this sort can work to the advantage of patentees, who draft their claims to select into categories that receive preferential treatment. When the courts tried to prohibit pure software patents in the past, patentees simply reframed their claims as "computer systems" to draft around the restriction. ${ }^{130}$ Likewise, when the PTO created a "second look" program for business method patents to provide for a more rigorous examination process, patent applicants reframed their claims so they could file their application in a different PTO division. ${ }^{131}$ A related problem with technology-specific patent laws is that they tend to become obsolete quickly. The Semiconductor Chip Protection Act is a famous example. ${ }^{132}$ Congress spent six years crafting this sui generis regime of intellectual property for semiconductors, but by the time they passed it into law the technology was already changing and the statute had become unnecessary. ${ }^{133}$

To make a compelling case for tailoring patent awards through industry- or technologyspecific rules, all of these objections must be addressed. The government must have access to the information necessary for tailoring. There needs to be a principled framework for deciding which inventions should receive more protection than others, and the framework needs to be simple

\footnotetext{
"even if it were possible to design industry-specific patent systems, the patent systems are unworkable since an innovation is not limited to a specific industry").

129 See Van Erp et al., Brain-Computer Interfaces for Non-Medical Applications: How to Move Forward, 45 COMPUTER-IEEE COMPUTER SOCIETY 26, _ tbl.1 (2012).

130 See BURK \& LEMLEY, supra note 22, at 98-99.

131 See JAFFE \& LERNER, supra note 25, at 204.

132 Semiconductor Chip Protection Act of 1984, Pub. L. No. 98-620, tit. III, 98 Stat. 3347 (codified as amended at 17 U.S.C. $\S \S 901-914(2006))$.

133 See Leon Radomsky, Sixteen Years after the Passage of the U.S. Semiconductor Chip Protection Act: Is International Protection Working?, 15 BERKELEY TEGH. L.J. 1049 (2000).
} 
enough for the government to administer it in a reliable and transparent manner. Finally, the government must be able to base its tailoring decisions on relevant economic factors, not arbitrary technological features, when resolving the line-drawing issues that inevitably arise during implementation of technology-specific rules. Otherwise, the public may very well be better served with uniform patent laws.

\section{Providing a Framework: the Argument for Tailoring Based on Time-to- Market}

There is a strong theoretical case for tailoring patent awards to each industry based on their need for protection and the likelihood that patents will stifle subsequent innovation in that field. However, unless the government has adequate information about inventions and an administrable framework to guide its tailoring decisions, uniform patent laws might be unavoidable. This section is an effort to provide that framework. It identifies an observable feature of inventions, the time-to-market, that correlates with their need for patent protection and the risk that patents will inhibit follow-on innovation, and that could be used to implement a simple and reliable tailoring regime.

First, the paper shows that the amount of time it takes to develop and commercialize inventions is a reliable indicia of the amount of patent protection needed to motivate their development. Within the standard model of patent policy, the appropriate patent award for an invention is a function of $\mathrm{R} \& \mathrm{D}$ costs, uncertainty, future revenue streams, and (to a lesser extent) the difficulty rivals will have in imitating the invention. Time-to-market provides a signal for all four of these factors.

Second, the paper demonstrates that patents are more likely to impede subsequent innovation when the average time-to-market for inventions is short, whereas the sequential- 
innovation problems will be less severe when inventions take a long time to develop. The economic models of sequential innovation suggest that longer patent terms can stifle technological progress in industries where earlier innovators will still develop their inventions under a shorter patent term, where those patents will read onto many subsequent improvements in the technology, and where transaction costs are high. The paper shows that these conditions are all correlated with the length of product life cycles in an industry - i.e., the amount of time older inventions are on the market before newer inventions replace them. The paper also shows - and explains why - the length of product life cycles is in turn a function of the time-to-market for new technologies. Since a shorter time-to-market strongly correlates with shorter product life cycles, and patents are more likely to stifle innovation in industries with short product life cycles, time-to-market is an indicia of the factors relevant to optimal patent life under conditions of sequential innovation.

Third, the paper argues that the average time-to-market in different industries is sufficiently observable to support a principled and reliable tailoring regime. The government can construct a reasonably designed system of tailored patent awards based on average time-tomarket that will promote additional innovation, avoid unnecessary deadweight loss, and avoid many of the situations where patents may be stifling innovation instead of promoting it. This time-to-market system of tailoring will provide the flexibility needed in the administration of technology-specific categories to avoid the complexity and line drawing problems that can be fatal to a tailoring regime.

\section{A. Industry Heterogeneity in the Average Time-to-Market for New Inventions}

Most new technologies require time and effort to develop into a commercial product. While it is well known that development cycles in the high-tech industries are much shorter than 
pharmaceuticals, the academic literature on patent policy tends to ignore most other industries.

This section draws on a variety of sources to present a picture of where various industries fall on the time-to-market spectrum.

Given the increasingly competitive environment in most industries, firms devote a great deal of effort to get their inventions onto the market as quickly as possible. ${ }^{134}$ Delays in R\&D give rival firms a chance to capture a greater share of the market, and diminish the firms' opportunity to earn a profit from their inventions. ${ }^{135}$ A 2007 report by Capgemini notes, "“[s]peeding time to market' is a typical mantra for many industries." ${ }^{136}$ A prominent consultant on product development strategies echoes this sentiment, describing a "preoccupation with reducing cycle time and speeding new products to market." 137 Even firms focusing on imitation as their primary R\&D strategy rush their development efforts to secure a viable market position; indeed, the strategy of competitive imitation is now known as being a "fast follower."138

${ }^{134}$ See Abbie Griffin, Product Development Cycle Time for Business-to-Business Products, 31 Indus. Marketing MgMt. 291 (2002) ("For the last 15 or more years, firms have worried about, and tried to shorten, the time it takes them to get new products to market."); Hadas Haran, Time to Market Research: Highlights and Key Findings, AMDOCS, 8 (2011) available through http://www.osstransformation.com/Time-to-Market (reporting findings from a survey that $70 \%$ of firms in the telecommunications industry say time-to-market is "very important" for remaining competitive in the field).

135 See Vincent A. Mabert et al., Collapsing New Product Development Times: Six Case Studies, 9 J. Product Innovation MGMT. 200, 203 (1992) ("It is abundantly clear to us that the threat of significant market share gains by competitors was a key stimulus in improving the new product development cycles at all of the companies."); Fred Langerak et al, Balancing Development Costs and Sales to Optimize the Development Time of Product Line Additions, 27 J. Product INNOVATION MGMT. 336, 339 (2010) ("The window of opportunity for a new product, in particular for product line additions, is finite. By taking too long to develop a new product, a firm may miss the window of opportunity. Customers already exposed to existing brands are not likely to postpone their purchase decision just to wait for a new product to come to market, especially if competitors already have introduced similar extensions.").

${ }^{136}$ Capgemini, Speeding Time to Market, Increasing Time in Market \& Maintaining Market Velocity: Best Practices in Driving TopLine Growth Through Innovation \& Collaboration 1 (2007).

${ }^{137}$ R.G. Cooper, Your NPD Portfolio may be Harmful to your Business's Health, 29 PDMA VISIONs 22-6 (2003).

138 See Constantinos C. Markides \& Paul A. Geroski, Fast Second: How Smart Companies Bypass RADical InNOVATION to ENTER AND DOMINATE NEW MARKETS 15, 119-138 (2005). 
Although firms use a variety of different strategies to shorten the time-to-market for their new inventions, ${ }^{139}$ there are limits to how quickly they can complete their R\&D. ${ }^{140}$ There is some room to speed up R\&D by devoting additional labor and resources to the project, but these investments often have steep diminishing returns. ${ }^{141}$ At a certain point, adding more people to a project can actually slow it down by creating coordination problems within the project team. ${ }^{142}$ The website for a product-development consulting firm offers the following advice to companies about the costs (and limitations) of accelerating R\&D times:

Time to completion is the key consideration for a product development project. Unfortunately, the tradeoff between resources and time is non linear and occasionally an uncertainty. If a project takes twice as long to conduct as required, one may need to triple, quadruple or more the assigned resources to halve the completion time. In fact in heavily resourced projects increasing resources can actually slow a project down. The time at which this happens is called the crash point. A relevant analogy to bear in mind is three women cannot have a baby in 3 months. ${ }^{143}$

In short, firms cannot speed through complicated and technologically challenging R\&D projects simply by spending more money on them. ${ }^{144}$ Moreover, certain aspects of the development process are inherently difficult to accelerate, such as product testing that requires real-world trials. ${ }^{145}$ Other aspects of the development timeline are simply outside the innovator's control, including the amount of effort needed to satisfy pre-market regulatory standards in areas such as

139 See Rocha \& Delamaro, supra note 36 (reviewing the academic literature on the various management strategies deployed to reduce development cycle times and speed time-to-market).

140 See Mabert et al., supra note 135, at 200.

141 See Langerak et al., supra note 135, at 338-39.

142 See Erran Carmel \& Barbara J. Bird, Small is Beautiful: A Study of Packaged Software Development, 8 J. HiGH TECH. MGMT. Res. 129 (1997).

143 Sensor Consultants, Tips $\mathcal{E}^{2}$ Facts - Organizing REDD for Success (2010), at http://www.sensorsresearch.com/articles/tips.htm (emphasis omitted).

144 See Griffin, supra note 134, at 293 exh.1.

145 See Adams, supra note 34, at 21-22; Amo van Wingerde, Testing of Rotor Blades of Wind Turbines, at http://www.ontario-sea.org/Storage/26/1788_Testing_of_Rotor_Blades_of_Wind_Turbines.pdf; infra note and text accompanying note 170 . 
pharmaceuticals, ${ }^{146}$ medical devices, ${ }^{147}$ aviation equipment, ${ }^{148}$ life insurance, ${ }^{149}$ and some securities products. ${ }^{150}$

These exogenous constraints on R\&D times lead to dramatic differences in the average time-to-market for different types of inventions. In parts of the financial industry, firm can often move from concept to product launch within a few weeks. ${ }^{151}$ There are a number of other industries where the average development cycle for new inventions is under a year, including consumer products, ${ }^{152}$ software components, ${ }^{153}$ and insurance. ${ }^{154}$ The time-to-market for

146 See Wyeth v. Levine, 555 U.S. 555, 566-567 (2009) (discussing the FDA's pre-market approval requirements for new drugs).

147 See Riegel v. Medtronic, Inc., 552 U.S. 312, 315-20 (2008) (discussing the FDA's pre-market approval requirements for medical devices).

148 See Federal Aviation Act of 1958, §603(a), 49 U.S.C. $§ 44704$.

${ }^{149}$ See Kelly Ireland, Life Insurers: Committed to Transparency, Clarity and Ethical Behavior in the Annuity Marketplace, American Law Institute, Life Insurance Company Products, SP029 ALI-ABA 235 (2008).

${ }^{150}$ See John C. Coates IV, Reforming the Taxation and Regulation of Mutual Funds: A Comparative Legal and Economic Analysis, 1 J. LEGAL ANALYSIS 591, 632-34 (2009).

${ }^{151}$ See Press Release, Octavian to Launch its Innovative Financial Products Account Opener for Financial Services Companies, Jan. 22, 2008, at http://www.reuters.com/article/2008/01/22/idUS141388+22-Jan-2008+PRN20080122; Finance America Capitalizes on a Digital Publishing Solution from HP to Keep its Products First in Brokers' Minds 2 (2004) at http://h10088.www1.hp.com/gap/download/FINANCE_AMERICA.pdf (noting that it is possible to create new financial products for mortgages "in about a week").

152 See Accenture, Innovation in Consumer Products: How to Achieve High Performance Through New Product InNOVATION 4 fg.2 (2008) (reporting that the average time-to-market for new consumer products ranges from approximately 3 to 13 months).

${ }^{153}$ See Martin L. Griss, Software Reuse: From Library to Factory, Hewlett Packard, Software Technology Laboratory, HPS-93-67 (1993) at http://www.hpl.hp.com/techreports/93/HPL-93-67.pdf (reporting an average time-to-market of 6 to 9 months for software components); Hadas Haran, Time to Market Research: Highlights and Key Findings, AMDOCS, 11-13 (2011), available through http://www.osstransformation.com/Time-to-Market (finding that 65\% of service providers in the telecommunications industry report that they are able to bring new products to market in less than 6 months); Jerry Krasner, Total Costs of Development: A Comprehensive Cost Estimation Framework for Evaluating Embedded Development Platforms (2003), at http://www.eurotech-inc.com/info/pdf/total-cost-of-development.pdf (reporting an average time-to-market for embedded software platforms that ranged between 8 and 14 months); Peter Rasmussen, Improved Efficiency and Faster Time to Market with Agile Development Practices (2010) at http://www.ibm.com/smarterplanet/global/files/danske_bank.pdf (describing how Danske Bank reduced its average time-to-market for new IT products from 14 months to 9 months); Carter Thomas, How Much Does It Cost to Develop an App?, Blue Cloud Solutions (Mar. 2011), http://www.bluecloudsolutions.com/blog/cost-developapp/ (discussing the costs of developing an application (or "app") for an iPhone); Mary Wu, Agile Method to Improve Delivery of Large-Scale Software Projects (2011) at http://wwwengr.sjsu.edu/ges/media/pdf/mse_prj_rpts/spring2011/Agile $\% 20$ Method $\% 20$ to $\% 20 I m p r o v e \% 20 D e l i v e r y \% 20$ of $\% 20$ Large-Scale $\% 20$ Software $\% 20$ Projects.pdf (reporting an average time-to-market of between 5 and 9 months for software projects in the case study). 
semiconductors is slightly longer, averaging 11 to 17 months. ${ }^{155}$ The average time-to-market for a medical diagnostic test (i.e., the laboratory technologies used to perform the diagnostic) is one to two years ${ }^{156}$ - although it may take many years of additional validation testing to establish the validity and utility of the underlying correlation before insurers will agree to pay for the test. ${ }^{157}$

While innovation occurs quickly in the high-tech industries, finance, consumer products, finance, and laboratory diagnostics, R\&D projects routinely take several years to complete in many other sectors of the economy. The average time-to-market for automobiles ${ }^{158}$ and complicated manufacturing equipment ${ }^{159}$ ranges from three to five years. Complex biomedical

154 See Andy Ferris, Product Development Issues: Speed to Market, Actuaries Club of the Southwest, Fall Meeting, San Antonio, TX, (2007), available at http://www.acsw.us/fall07/Ferris.pdf (reporting an average time-to-market of between 3 and 12 months for new insurance products).

155 See Rahul Kapoor et al., Managing Complexity and Change in the Semiconductor Ecosystem: FINDINGS FROM THE WHARTON-ATREG INDUSTRY STUDY 5 (2012) ("The average time-to-market, defined as the period from design start to mass production, is about 11 months for a revision of an existing product design. It increases to about 17 months for a new product design.").

156 See Rebecca Henderson \& Cate Reavis, Eli Lilly: Recreating Drug Discovery for the 21st Century 16, MIT Sloan, Doc. No. 07-043 (2008), at https://mitsloan.mit.edu/MSTIR/IndustryEvolution/RecreatingDrugDiscovery/Documents/07-043-Recreating-Drug-Discovery.pdf.

${ }^{157}$ See Pressman, supra note 160, at 15 (reporting that the average time from patenting to first royalties is 7 to 9 years for the gene patents held by the NIH or universities that are licensed to private industry to create diagnostic tests). These figures refer the to time-to-market for the correlation component of diagnostic innovation, where the patented invention concerns the medical relevance of a particular observable feature that can guide treatment decisions. The development cycles for diagnostics greatly vary depending on the regulatory environment and whether it is an entirely new diagnostic or just an improvement in the testing technology for an older diagnostic. See New Report Provides High-level Data Benchmarks in Key Areas to Help Teams Achieve Success in their IVD Development and Marketing Efforts, Apr. 8, 2008, at http://www.businesswire.com/news/home/20080408005068/en ("It is impossible to present a standard benchmark for the amount of time it takes to develop diagnostics products. While the evolution of some products takes more than 10 years, other IVDs fly through development and hit the market in less than three years. ... IVD development time depends largely on where companies "jump off" with their new products. While some companies' products are brand new technologies, other diagnostics are conjugations of existing products and technologies. Usually, developing an entirely new diagnostic requires significantly more time than improving on an existing product line.").

${ }^{158}$ See Ron Adner, Matching Your Innovation Strategy to Your Innovation Ecosystem, HARV. Bus. Rev. April 2006 (noting that an "average OEM takes three to four years to move a car from design to volume production"); Charles H. Fine et al., The U.S. Automobile Manufacturing Industry, U.S. Dept. Commerce, Office of Technology Policy (1996) (finding that the average time-to-market for U.S. automakers was 52 months); Abbie Griffin, Modeling and Measuring Product Development Cycle Time Across Industries, 14 J. Engineering \& Tech. Mgmt. 1, 2 thl.1 (1997) (reporting that the average time-to-market for new cars is 3 to 5 years).

${ }^{159}$ See Griffin, supra note 158, at 2 tbl.1 (reporting an average time-to-market of 4 to 7 years for construction equipment and jet engines, and 3 to 5 years for copying equipment); Sarah Lubik et al., Market-Pull and Technology- 
research tools ${ }^{160}$ and veterinary vaccines ${ }^{161}$ take five years or more on average to reach the market. The average time-to-market for medical devices is only two to five years, ${ }^{162}$ although first-in-class devices can take up to 10 years to reach the market. ${ }^{163}$

There are a few industries where R\&D times are much longer. The average time-tomarket for radiopharmaceutical diagnostics is seven to nine years, ${ }^{164}$ while new drugs take 12 to 16 years on average to reach the market, depending on the therapeutic class. ${ }^{165}$ Time-to-market for solar panel technology averages 8 years, ${ }^{166}$ and the development cycle for fuel cells is even longer. ${ }^{167}$ Once these inventions are on the market, it can take another decade for to reach the

Push in Manufacturing Start-Ups in Emerging Industries, 24 J. Manufacturing Tech. MgMt. 10 (2013) (reporting that the average time-to-market in their sample of high-tech manufacturing start-ups was approximately 3 to 4 years).

${ }^{160}$ See Lori Pressman, DNA Patent Licensing Under Two Policy Frameworks Implications for Patient Access to Clinical Diagnostic Genomic Tests and Licensing Practice in the Not-for-Profit Sector, BlOOMBERg BNA LIFE SCI. L. \& IND. ReP. 15, May 23, 2012 (finding that for the gene patents held by the NIH or a university that are licensed to private industry to be developed as a reagent, the average time from patenting to receipt of first royalties was 5 years).

161 See P.H. Flore, Commercialization of Veterinary Viral Vaccines, 5 Animal Health Res. Rev. 239 (2004) (noting that "the average development time of a novel [veterinary] vaccine is at least 5 years").

162 See Arthur H. Combs, Medical Device Development: Contrasting Key Elements with Drug Development, Future Tech Strategies, at http://www.bioscimn.project.mnscu.edu/vertical/Sites/\%7B06AED276-B425-440BA665A601B55956D1\%7D/uploads/\%7B37FDA556-E783-4E64-AF60-71DEB5495FC8\%7D.PDF (last accessed on _) (reporting that the average time-to-market for a basic new medical device is 3 to 5 years, with a minimum of 2 years and a maximum of 10$)$.

163 While the average time-to-market for most medical devices is 3 to 5 years, it can be 10 or more years for first-inclass devices. See Combs, supra note 162; Aaron V. Kaplan et al., Medical Device Development: From Prototype to Regulatory Approval, 109 CirCULATION 3068 (2004) (describing the preclinical development and regulatory testing requirements for medical devices that make R\&D times for first-in-class devices similar new drugs).

164 See Richard G. Zimmermann, Why are Investors Not Interested in My Radiotracer? The Industrial and Regulatory Constraints in the Development of Radiopharmaceuticals, _ NuCLEAR MEDicine AND BIOLOGY _ (2013) (reporting that the average time-to-market for radiopharmaceutical diagnostics is 7 to 9 years).

165 See Joseph A. DiMasi, New Drug Development in the United States from 1963 to 1999, 69 CLinical Pharmacology AND THERAPEUTICS 286, 292 fg. 6 (2001).

166 See Pennsylvania State University, Materials Research Institute, State "Enlightenment" on the Subject of Solar Cells (2006), at http://www.mri.psu.edu/news/2006/2006_taylor_lecture/ (noting that the current time-to-market for solar technology is 8 years).

167 See Panayotis Christidis, Trends in Vehicle and Fuel Technologies: Overview of Current Research Activities, European Science and Technology Observatory 6 (2003) (reporting that the development time-frame for fuel cells is between 15 and 25 years); Sunita Satyapal, Hydrogen Fuel Cells \& Infrastructure Technologies Program, Technology Commercialization Showcase 16-41 (2008) at http://techportal.eere.energy.gov/commercialization/pdfs/2008_h2_fuel_cells.pdf (listing the estimated time-to-market (going forward) for a variety of fuel-cell technologies in various stages of development). 
point of widespread commercial adoption. ${ }^{168}$ Not all clean-energy technology fits this mold, however. Wind power is said to have a "very short" time-to-market relative to most other cleanenergy technologies. ${ }^{169}$ In the oil and gas industry, new drilling technologies take 16 years on average to commercialize effectively, mostly due to the time required for field-testing. ${ }^{170}$

TABLE 1

\begin{tabular}{|c|c|}
\hline TEGHNOLOGY & $\begin{array}{l}\text { AVERAGE TIME- } \\
\text { TO-MARKET }^{*}\end{array}$ \\
\hline Financial products & Weeks to months fin151 \\
\hline Insurance products & 3 to 12 months fri 154 \\
\hline Consumer products & 3 to 13 months fri 152 \\
\hline Software & 5 to 14 months fin 153 \\
\hline Semiconductors & 11 to 17 months fin 155 \\
\hline Medical Diagnostics (new laboratory test) & 1 to 2 years fin 156 \\
\hline Complicated Manufacturing Equipment & 3 to 5 years fin 159 \\
\hline Automobiles & 3 to 5 years fn 158 \\
\hline Medical Devices (follow-on) & 3 to 5 years fn 162 \\
\hline Biomedical Research Tools & 5 years fin 160 \\
\hline Veterinary Vaccines & $5+$ years fn 161 \\
\hline Solar Panels & 8 years fin 167 \\
\hline Radiopharmaceutical Diagnostics & 7 to 9 years fn 164 \\
\hline Medical Devices (first-in-class) & 5 to 10 years fin 163 \\
\hline Medical Diagnostics (new diagnostic correlation) & 7 to 10 years fin 157 \\
\hline Fuel Cells & 7 to 25 years ${ }^{\text {fn } 167}$ \\
\hline Oil \& Gas Drilling & 16 years* fn 170 \\
\hline Pharmaceuticals & 12 to 16 years fin 165 \\
\hline
\end{tabular}

It is clear that the time-to-market for new inventions varies tremendously across industries and technology types. Table 1. Financial products and pharmaceuticals rest at opposite ends of the spectrum, and development cycles in software and semiconductors are much closer to the former than the latter. This much was already known. Some of the other figures are a little surprising. Average development times within the health care and biotechnology industries cover

168 Bernice Lee et AL., Who Owns Our Low Garbon Future?: InTellectual Property and ENERGy TECHNOLOGIES vii (2009) ("Analysis shows that inventions in the energy sector have generally taken two to three decades to reach the mass market. This time lag is mirrored by the time it takes for any patented technology to become widely used in subsequent inventions. Data on the top 30 most-cited patents from each of the six sectors examined here indicate that it takes between 19 and 30 years with an average of around 24 years.").

169 Rudolf Rechsteiner, Wind Power in Context - A Glean Revolution in the Energy Sector 9 (2008).

170 See W. Howard Neal, Oil and Gas Technology Development, Topic Paper \#26, Working Document of the NPC Global Oil \& Gas Study 1 (2006); id. at 12 fg.IVF.1. Given the long development times of breakthrough drilling technologies, apparently all of those inventions are funded by the government. See Stephen M. Cassiani, Exploration Technology, Topic Paper \#21, Working Document of the NPG Global Oil \& Gas Study 1 (2007) ("[D]evelopment of new, breakthrough, drilling-technology advances is necessarily long-range and requires significant pre-investment. All of the breakthrough technologies are funded to a large extent by national governments as well as large oil and gas companies."). 
an incredibly wide range of 1 to 16 years, depending on the type of technology. Patent scholars have overlooked the extraordinarily lengthy R\&D times for many technologies in the oil and gas industry, and the time-to-market in clean energy is underappreciated. It is also worth noting that development cycles vary within each of these areas, sometimes along very predictable lines. ${ }^{171}$

\section{B. Time-to-Market Strongly Correlates with the Primary Predictors of Optimal Patent Length}

This section argues that the average time-to-market in an industry is among the most reliable of signals for optimal patent life. Firms will not develop an invention that takes a long time to reach the market unless they expect it to generate enough revenue to compensate for the higher financing costs as more capital is tied up for longer and the value of future revenue streams is discounted by time. To make matters worse, the inventions with longer development cycles typically required higher out-of-pocket R\&D expenses and involved a greater risk of failure. Taken together, these factors suggest that an invention's time-to-market will have a tremendous impact on the amount of protection needed to motivate its $\mathrm{R} \& \mathrm{D}$. The strength of this relationship varies depending upon the extent to which the inventor's development efforts are vulnerable to free riding, but the positive correlation between time-to-market and optimal patent length will hold strongly under most circumstances.

\footnotetext{
171 See Coates, supra note 150, at (noting that the regulatory approval process for innovative mutual fund products can sometimes take years); Sophie Hooge \& Armand Hatchuel, Value Indicators and Monitoring in Innovative PDM: A Grounded Approach, XVe International Product Development Management Conference, Hambourg, Germany, tbl.2 (2008) (reporting R\&D times for the automaker Renault SAS that ranged from 6 months to greater than 3 years); Sachin P. Kamat, Time to Market, 1 IEEE Consumer EleGtronics Magazine 40 (2012) (reporting that the average time-to-market for software applications on mobile devices is between 17 and 26 months, roughly double the average R\&D times reported for many other software components - see supra note 153); Mabert et al., supra note 135, at 205 tbl. 1 (noting that several of the firms studied reported that the normal time-to-market for their new products was "highly variable"); McKinsey \& Company, McKinsey on Semiconductors, No. 1, 58 exh. 1 (2011) (reporting that average time-to-market in the semiconductor industry that ranges from 12 to 16.6 months for some products to 25 to 47 months for others).
} 


\section{Time-To-Market as a Signal of REDD Costs, Uncertainty, and Future Revenue Streams}

The optimal length of patent protection for any given invention is the amount of time needed for the innovator to recover its total R\&D investment once it has commercialized the invention. This figure is primarily determined by three factors: $R \& D$ costs, the probability of success, and the revenue streams generated by the invention. ${ }^{172}$ The time-to-market for inventions correlates with all three of these factors. The inventions that take longer to reach the market have substantially higher $\mathrm{R} \& \mathrm{D}$ costs on average, usually involve a much greater degree of uncertainty, and generate smaller revenue streams once they are on the market due to discounting for the time value of money ${ }^{173}$ and costs of capital. Time-to-market therefore provides a powerful indicator of the appropriate patent term for one invention relative to another, and for certain types of technologies relative to others. Put simply, it is a reliable tool for tailoring.

Ideally, the patent system should provide inventions with the minimum amount of protection necessary to motivate their timely R\&D. Some inventions do not require any protection, but others will not reach the public without it. ${ }^{174}$ For the patent system to successfully call forth the inventions that depend on it, the patent term must be long enough for firms to anticipate a profit from the necessary investment in R\&D. ${ }^{175}$ Inventions that require more expensive $\mathrm{R} \& \mathrm{D}$ need longer exclusivity periods on average to generate enough sales revenue to cover their costs. ${ }^{176}$ The same is true for $\mathrm{R} \& \mathrm{D}$ projects involving greater uncertainty, since the

\footnotetext{
172 See Scherer, supra note 22, at 426-28; SHAVELL, supra note 22, at 146.

173 The term "time value of money," a central concept in financial accounting, "refers to the economic premise that a dollar received today is worth more than a dollar received tomorrow," and indicates that there is an "economic cost [to] receiving a deferred payment, i.e., a payment that is made after the date of the transaction to which it relates." Stephen F. Gertzman, Definition of "Time Value of Money", FED. TAX Accounting 111.01 (2011).

174 See supra notes and text accompanying notes 32-34, and 39-42.

175 See Scherer, supra note 22 at 426.

176 See, e.g., SHAVELL, supra note 22, at 146 ("[T] he desirable length of property rights should be higher the greater the development costs, other things equal.").
} 
anticipated returns from an $\mathrm{R} \& \mathrm{D}$ investment must be sufficient to compensate for the risk of failure. ${ }^{177}$ Inventions that generate lower annual sales revenues are also more likely to need a longer monopoly period to be profitable, since it takes more time for the invention to produce enough revenue to cover its $\mathrm{R} \& \mathrm{D}$ costs. ${ }^{178}$

The standard economic analysis of optimal patent length provides several reasons to think that inventions with longer development cycles will require a longer patent term on average to motivate their R\&D. First, the duration of an R\&D projection has a direct impact on total R\&D costs because of the time value of money. The more time it takes for an invention to reach the market, the longer firms must wait to see a return on their investment, which means that the investment has higher opportunity costs. Those costs are particularly important with R\&D projects, since the costs of capital for $\mathrm{R} \& \mathrm{D}$ tend to be higher than for other types of investments ${ }^{179}$ - especially when funded by outside investors. ${ }^{180}$ If a firm's cost of capital is in the range of 10 to 12 percent, which appears to be typical for $\mathrm{R} \& \mathrm{D},{ }^{181}$ the anticipated time to market

\footnotetext{
177 See Scherer, supra note 22, at 428.
}

178 See Scherer, supra note 22, at 426-28. To the extent that inventions with higher social value also generate more in sales revenue due to stronger consumer demand, this observation suggests that the government might want to offer shorter patent terms to inventions of greater social value. As Steven Shavell explains, however, there is "no clear relationship between the social value of an innovation and the optimal length of property rights," since "[m]ore valuable innovations lead to higher monopoly profits per year, tending to reduce the period necessary to cover development costs, but more valuable innovations are also more desirable to stimulate (and may cost more to develop), tending to raise the desirable period of property rights protection." SHAVELL, supra note 22, at 146.

179 See Partnoy, supra note 22, at 19; Charles P. Himmelberg \& Bruce C. Petersen, R\&D and Internal Finance: A Panel Study of Small Firms in High-Tech Industries, 76 REV. ECON. \& STAT. 38, 38-42 (1994).

180 See Bronwyn H. Hall \& Josh Lerner, The Financing of RED and Innovation, 1 HANDBOOKS IN ECONOMICS: Economics Of InNOvation 613-618 (Bronwyn H. Hall \& Nathan Rosenberg eds., 2010). There are three main reasons why it is usually more expensive for entrepreneurs and firms to finance their R\&D with external capital as opposed to retained earnings. First, researchers may have better information than outside investors about the probability of success in their research, leading to a market for "lemons" problem in the search for R\&D funding. Id. at 614-15. Second, reliance on outside investments creates a moral hazard problem because researchers and managers often have different incentives than the outside investors, such as a desire for unnecessary perks or risk aversion in the selection of R\&D projects. $I d$. at 615-16. Third, there are also tax disadvantages to financing R\&D with debt as opposed to earnings. Id. at 617-18.

181 See Frank Kerins et al., Opportunity Costs of Capital for Venture Capital Investors and Entrepreneurs, 39 J. FINANCIAL \& QUANTITATIVE ANALYSIS 385 (2004). 
has a dramatic effect on total project costs. ${ }^{182}$ In the pharmaceutical industry, where it is estimated that the average capitalized cost of bringing a new drug to market is approximately $\$ 1.2$ billion, over half of those costs are due to the time value of money invested. ${ }^{183}$ Interviews of R\&D managers outside of the pharmaceutical industry also verify that firms "are thinking about the cost of capital," and that "the estimated time completion period[s] are important factors to support a project." 184

The time firms spend developing their inventions also diminishes the present value of the future revenue streams those inventions might generate, which makes it harder for firms to recoup their $\mathrm{R} \& \mathrm{D}$ investments. When firms decide whether to invest in an $\mathrm{R} \& \mathrm{D}$ project, they weigh the cost of that $\mathrm{R} \& \mathrm{D}$ and its risk of failure against the sales revenues they expect to earn from the invention if it reaches the market. ${ }^{185}$ The value of future revenue streams is always discounted to reflect the costs of capital. The more time it takes for an invention to begin generating sales revenue, the more those revenues are discounted. Assuming a discount rate in the range of 10 to 12 percent, development cycles will have a large effect on the net present value of most R\&D projects. ${ }^{186}$

182 See National institute of Standards and Technology (NIST), Economic Analysis of the TEGHNOLOGY INFRASTRUCTURE NEEDS OF THE U.S. BIOPHARMACEUTICAL INDUSTRY, ch.5, 1-26 (2007).

183 See Joseph A. DiMasi \& Henry G. Grabowski, The Cost of Biopharmaceutical REDD: Is Biotech Different?, 28 MANAGERIAL \& DECISION ECON. 469, 469, 475 (2007).

184 See Roli Varma, Project Selection Models or Professional Autonomy?, 17 PROMETHEUs 269, 277 (1999).

185 See David J. Brunner et al., REDD Project Selection and Portfolio Management, in HANDBOOK OF TECHNOLOGY AND Innovation MGmt. 216-220 (Scott Shane ed. 2008); Marcus Hartmann \& Ali Hassan, Application of Real Option Analysis for Pharmaceutical REDD Project Valuation - Empirical Results from a Survey, 35 RES. POL. 343, 345-46, 348 (2006); Petri Suomala, Life Cycle Dimension of New Product Development Performance Measurement, 8 InT'L J. InNOVATION MGMT 193 (2004).

186 See, e.g., F. Peter Boer, Risk-Adjusted Valuation of REDD Projects, 48 RES.-TECH. MGMT. 50 (2003) (noting that the time value of money frequently plays a decisive role in the decisions about which R\&D projects to fund); Richard J. Gilbert, Dollars for Genes: Revenue Generation by the California Institute for Regenerative Medicine, 21 BERKELEY TECH. L.J. $1107,1122-24$ (2006). 
These discounting effects alone might justify tailoring patent awards based on the time-tomarket for new inventions. Indeed, Frank Partnoy makes this exact argument in a prior (unpublished) article that questions the wisdom of awarding 20-year monopolies over new financial products. ${ }^{187}$ Partnoy uses a model of optimal patent length that depicts R\&D investments as annuities, and on that basis, argues that the patent term should vary with interest rates, ${ }^{188}$ a firm's cost of capital, the time-to-market for new inventions in a field and a few other factors. ${ }^{189}$ He notes that one of the clearest implications of his model is that development time has a huge effect on optimal patent life. ${ }^{190}$ Although the argument is sound, Partnoy is greatly underestimating the strength of the correlation between time-to-market and optimal patent length through his analogy to annuities.

Unlike the time to maturity for an annuity, the time-to-market for new inventions not only has a direct effect on their costs of capital and the future revenues streams they must generate; it is also associated with higher out-of-pocket R\&D expenses and greater uncertainty. ${ }^{191}$ When an invention takes a long time to reach the market, it is rarely due to a lack of effort on the

187 See Partnoy, supra note 22.

188 Varying the patent term along with fluctuating interest rates might be unnecessary because firms try to smooth their R\&D investments to avoid any short-term changes in their workforce of scientists and engineers. See supra note 180 .

189 See Partnoy, supra note 22 at 22-27; 43-45. Partnoy emphasizes four variables in his calculation of optimal patent length: the "expected flow rate of profits" (i.e., overall profits from the invention), the "structure of the expected flow rate of profits" (i.e., whether the profits are front-loaded), the "length of time until the flow rate of profits begin" (i.e., development time), and the "costs of capital." Id. at 23 \& 24. Amir Khoury offers a much briefer (and less formal) discussion of the relationship between time-to-market and optimal patent length, but seems to reach a similar conclusion. See Khoury, supra note 22, at 408.

190 See Partnoy, supra note 22 at 22-27; id. at 27 ("Conservatively, assume the difference between the timing of the first cash inflow for the financial services and pharmaceutical industries is five years. It is a fairly straightforward conclusion that the optimal patent term for financial products is roughly five years shorter than that for drugs.").

${ }^{191}$ From the perspective of a firm managing a particular R\&D project, the relationship between development time and out-of-pocket R\&D expenses usually runs in reverse - i.e., firms can accelerate their R\&D projects by devoting more resources to them. Assuming that firms are already trying to strike the profit-maximizing balance between cost and speed in their R\&D, however, the projects with longer development times will involve higher out-of-pocket $\mathrm{R} \& \mathrm{D}$ costs on average. 
part of the patentee. ${ }^{192}$ Under most circumstances, firms try to get their inventions to market as quickly as possible to avoid losing market share to competitors. ${ }^{193}$ When one invention takes much longer to develop than another, it is usually because it involved a more complicated and labor-intensive R\&D effort. ${ }^{194}$ Over $50 \%$ of costs in the typical R\&D project are the wages of scientists and engineers. ${ }^{195}$ To the extent that a longer time-to-market corresponds to additional work hours devoted to the project, therefore, it will also correspond to higher total out-of-pocket $\mathrm{R} \& \mathrm{D}$ costs.

Inventions with a longer time-to-market also tend to involve a much greater degree of technological and commercial uncertainty. Studies find that the average time-to-market for an invention is strongly correlated with its complexity, technical difficulty, innovativeness, and general "newness" (the amount of change from previous versions of similar products). ${ }^{196}$ Industry surveys find that the average time-to-market for a "new-to-the-world" invention is anywhere from three to six times longer than for an incremental invention. ${ }^{197}$ The anecdotal evidence suggests that the most cutting edge technologies take even longer to reach the market. ${ }^{198}$

\footnotetext{
192 See supra notes and text accompanying notes 134-136. Despite the intense pressure on firms to finish developing their inventions as quickly as possible, there are situations where firms hold onto their patents for the "option value" of developing the claimed invention in the future. See Cockburn \& Henderson, supra note, at I.2 (finding that on average, firms hold roughly $20 \%$ of their patents for the option value of "potential future own business"). In these cases, the relationship between time-to-market and optimal patent life matches Partnoy's annuity model.

193 See supra text accompanying notes 134-138.

194 See Griffin, supra note 134, at 293 exh.1.

195 See Hall \& Lerner, supra note 180, at 612.

196 See Griffin, supra note 134, at 292 ("Nearly all the empirical results relating to project strategy are unsurprising. Newer, bigger, more complex, more technically challenging and more innovative projects are all associated with longer development times ...."); $i d$. at 293 exh.1 (reviewing the literature on the factors associated with increases in product development times).

197 See Adams, supra note 34, at 13; Griffin, supra note 134, at 297 tbl.4 (reporting an average cycle time of 53.2 months for inventions that are new-to-the-world, 36 months for new product lines, 22 months for next generation improvements, and 8.6 months for incremental improvements).

198 See Erp et al., supra note 129, _ tbl.1 (estimating that the time-to-market for applications of brain-computerinterface technologies in "control devices" and "safety \& security" is 5 to 10 years).
} 
Since the time-to-market for inventions is correlated with all three of the factors widely accepted to be the determinants of socially optimal patent length, it may be a uniquely powerful lever for tailoring in patent law. Inventions with a short time-to-market presumably need substantially less protection on average compared to ones that take much longer to commercialize. If the patent system were to respond to those differences, it could promote additional innovation while diminishing the amount of consumer deadweight loss caused by excessive patent grants.

\section{The Option of Adding Imitation Costs to the Equation}

The only complicating factor in the otherwise unidirectional relationship between timeto-market and optimal patent length is the extent to which the inventor's development efforts are vulnerable to free riding. When longer development cycles correspond to equally higher imitation costs and longer lags, the relationship between time-to-market and optimal patent length will be weaker, although still positive in most cases. The relationship will be stronger to the extent that imitation costs and lag are unrelated to the innovator's development time. The government could tailor patent terms without considering imitation costs, but a more nuanced system would incorporate them into the analysis.

The patent system tends to be much more important for sustaining private sector R\&D in innovations that are much easier to imitate than to create. ${ }^{199}$ While scholars usually emphasize imitation costs when discussing whether certain inventions should be patentable, it is also relevant for determining an invention's optimal patent length. A shorter patent term is more likely to be sufficient for inventions that are costly and time-consuming to imitate, since the inventor can recoup some of its $\mathrm{R} \& \mathrm{D}$ expenses and reach the break-even point on their

199 See supra text accompanying notes 31-39. 
investment after its patent ends. On the other hand, patent expiration opens the door to steep price competition for inventions that are easy to copy, which can quickly erode the innovator's profit margins. Under these circumstances, the patent term must be long enough for firms to earn a sufficient profit from their R\&D investment before they lose their monopoly. ${ }^{200}$

Imitation is usually faster and less expensive than innovation, ${ }^{201}$ but in most cases, copycat firms must replicate at least some of the innovator's R\&D efforts to imitate the invention. There are times when the forces affecting an invention's time-to-market have a nearly identical impact on the time-to-market of imitations (e.g., the effort needed to establish the necessary manufacturing and distribution capabilities). When this is true, it will substantially (but not entirely) offset the need for a longer patent term normally indicated by a lengthy development time, ${ }^{202}$ since inventions that are costly to imitate typically experience less price competition following patent expiration. ${ }^{203}$

On the other hand, when the economic forces that lengthen an invention's time-tomarket do not have the same effect on the time and expense needed to imitate it, the correlation between development time and optimal patent length is much stronger. By reverse engineering and then copying an invention, imitators often avoid much of the painstaking work involved in perfecting the design of a complicated new product; and by copying the essential features of the

\footnotetext{
200 See Federal Trade Commission (FTG), Emerging Health Gare Issues: Follow-On Biologic Drug Competition, Appendix A (2009) (discussing the calculation of the "break even point" for a new biologic drug given the heightened restrictions on generic (or "biosimilar" entry) following patent expiration).

201 See supra note 33.

202 Since innovators usually appropriate only a small portion of the social value from their inventions, see supra note 49, a longer time-to-market will still correspond to a longer optimal patent length even when imitation takes just as long as innovation.

${ }^{203}$ Cf. Mazzoleni \& Nelson, supra note 90, at 1047-48 (arguing that investments in developing and commercializing inventions are much less likely to require strong patent protection on the underlying invention when they are not susceptible to free-riding imitation). It is conceivable that there is a class of inventions where longer development times corresponds to higher imitation costs, perhaps because firms are spending time developing their products to make them harder to reverse engineer.
} 
original invention, they are frequently able to skip some of the costly product testing and market research important for commercialization. ${ }^{204}$ In most of the fields where the time-to-market for new inventions is unusually long, including pharmaceuticals, oil and gas extraction, and clean energy, much of the delay to market is due to this type of product and market testing. ${ }^{205}$ Under these circumstances, the inventions that take longer to develop are less likely to generate sufficient profits to help cover their R\&D costs after their patent expires, which calls for a longer patent term.

Since imitation costs are lower than the costs of invention in most cases, a longer time-tomarket will usually correspond to increased vulnerability to free riding, and thus a greater need for patent protection. However, unlike the correlation between time-to-market and the primary considerations of optimal patent length ( $\& \& D$ costs, uncertainty and revenue streams), the impact of time-to-market on imitation costs will vary across industries to a greater degree. This suggests that any tailoring based on time-to-market should also consider differences in imitation costs when possible.

\section{Policy Implications}

The most obvious policy implication of this argument is that patent awards should be much longer in industries with a longer average time-to-market for inventions relative to industries with shorter development cycles. Most patent scholars already assume that a lengthy

\footnotetext{
204 See Jonathan D. Bohlmann et al., Deconstructing the Pioneer's Advantage: Examining Vintage Effects and Consumer Valuations of Quality and Variety, 48 MGMT. SCI. 1175, $1119-1120$ (2002); SCHNAARS, supra note 34, at 195-210 \& 218-221; Ted Sichelman, Commercializing Patents, 62 STAN. L. REV. 341, 360-62 (2010).

205 In the oil and gas industry, most of the development time (and costs) for new extraction technologies is associated with "proof of concept" tests and field-testing. See Neal, supra note 170, at 9-10. The development of fuel cell technology and many other green-tech products similarly requires many years of product testing before it can be commercialized. See THe Fuel Gell TodAy: Industry Review 2011, 20 (2011) (noting that the development of fuel cell technology for cars "is not a quick process and many years of development and testing must be undertaken to ensure the product is fit for market before introducing it to the public").
} 
patent term is more important for promoting innovation in the biopharmaceutical industry relative to finance, software and semiconductors. In these cases, the insight that time-to-market corresponds to optimal patent length merely confirms the obvious. But it also helps to place all of the other industries along the spectrum of optimal patent life, even when scholars know much less about the patterns of $\mathrm{R} \& \mathrm{D}$ in their sectors of the economy. The time-to-market inquiry suggests that oil \& gas drilling technologies, fuel cells and solar panels probably need a much longer patent term to motivate their development compared to wind-energy technologies. It also indicates that innovation in the consumer-product industries is generally much closer to semiconductors than pharmaceuticals in terms of optimal patent length.

Another implication of the link between time-to-market and optimal patent life is that certain types of inventions within each industries may need more protection than others. The first-in-class medical devices that often take up ten years to develop presumably require a longer term than the incremental-improvement devices that follow it, where the average time-to-market is only 2 to 3 years. ${ }^{206} \mathrm{In}$ the diagnostics industry, where it normally takes much longer to clinically validate a medical correlation (e.g., to show that a particular drug is more or less likely to be effective depending on some observable variable) than to develop the testing equipment, ${ }^{207}$ the former may need a much longer patent term than the latter. If this is true, then the Supreme Court's recent decision in Mayo v. Prometheus - which ruled that firms cannot patent the use of a medical correlation in medical practice, and instead must rely on patents covering the diagnostic testing equipment - may have been exactly the wrong result. ${ }^{208}$

\footnotetext{
206 See supra notes and text accompanying notes 162-163.

207 See supra note 157.

208 Mayo Collaborative Services v. Prometheus Laboratories, 566 U.S. _ (2012).
} 
Tailoring patent terms within the pharmaceutical industry might be particularly beneficial to the public, since drug patents seem to play a critical role in motivating private sector R\&D, but they also impose substantial costs on consumers and taxpayers. Pharmaceutical companies spend tens of billions of dollars on R\&D each year to developing a relatively small number of new products. ${ }^{209}$ These products tend to generate substantial revenues for their manufacturers up until the very end of their patent term. ${ }^{210}$ Generics usually enter the market as soon as those patents expire, ${ }^{211}$ forcing the pharmaceutical companies to compete with products that are practically identical to their own and cost a quarter of the price on average. ${ }^{212}$ More so

209 See Joseph Golec \& John Vernon, Measuring US Pharmaceutical Industry REDD Spending, 26 PhaRmacoeconomics 1170 (2008).

${ }^{210}$ See Charles Clift, The Value of Patent Term Extensions to the Pharmaceutical Industry in the USA, 5 JOURnAL OF GENERIC Medicines: The Business Journal for the Generic Medicines Sector 201 (2008); Henry Grabowski \& Margaret Kyle, Generic Competition and Market Exclusivity Periods in Pharmaceuticals, 27 MANAGERIAL \& Decision Econ. 1, 9 tbl. 3 (2007). Drugs actually tend to be most profitable toward the end of their patent life, with peak sales revenue somewhere between 8 and 12 years after they first entered the market - usually just before their patents expire. See Joseph A. DiMasi et al., RङD Costs and Returns by Therapeutic Category, 38 DRUG INFORMATION JOURNAL 211, 219 fg.5 (2004); Henry G. Grabowski \& John Vernon, The Distribution of Sales Revenues from Pharmaceutical Innovation, 18 Pharmacoeconomics Suppl. 1, 21 (2000).

211 There is an extensive academic literature on the various strategies drug companies sometimes use to keep generics off the market beyond the expiration of their core drug patents. Scott Hemphill and Mark Lemley recently argued that the attempt in the Hatch-Waxman Act to facilitate generic competition through patent challenges "isn't working" because "[p]harmaceutical patent owners have responded to Hatch-Waxman with a sophisticated program of 'product lifecycle management,' which is code for finding ways to extend exclusivity as long as possible." C. Scott Hemphill \& Mark A. Lemley, Earning Exclusivity: Generic Drug Incentives and the Hatch-Waxman Act, 77 ANTITRUST L.J. 947, 948 (2011). Although it is true that drug companies try to block generic entry through the patent system for as long as possible, most of their strategies failed. See Rebecca S. Eisenberg, The Role of the FDA in Innovation Policy, 13 Mich. Telecomm. \& Tech. L. Rev. 345, 354 \& n.37 (2007). Indeed, a recent study by Scott Hemphill and Bhaven Sampat finds little evidence that these later-filed patents affect the date of generic entry, which they interpret as evidence that the patent system is working well in this context. See C. Scott Hemphill \& Bhaven N. Sampat, Weak Patents Are a Weak Deterrent: Patent Portfolios, the Orange Book Listing, NBER Working Paper _ (2011). The current concern is mostly about the use of reverse-payment settlements between pharmaceutical companies and generic manufacturers, which probably allows companies to delay generic entry with relatively weak patents. See, e.g., Einer Elhauge \& Alex Krueger, Solving the Patent Settlement Puzzle, 91 Tex. L. Rev. 283 (2013); Hemphill \& Lemley, supra. The Supreme Court will hear arguments on the legality of this practice in March of 2013. However, it is worth noting that despite all the different tactics drug companies have developed to keep generics off the market, the average effective patent life for new drugs - time from regulatory approval to generic entry - has remained unchanged at 11 to 12 years. See Grabowski \& Kyle, supra note 210, at 6 fg. 4; C. Scott Hemphill \& Bhaven N. Sampat, Evergreening, Patent Challenges, and Effective Market Life in Pharmaceuticals, 31 J. Health Econ. 327 (2012).

212 See United States Government Accountability Office (GAO), Drug Pricing: Research on Savings FROM GENERIC DRUG USE, 1, GAO-12-371R (2012). Pharmaceutical companies typically lose about 70\% of their sales within the first 6 months of generic competition. See Datamonitor, US Most Susceptible to Brand Erosion Post Patent Expiry, Jan. 13, 2011, at http://about.datamonitor.com/media/archives/5293. Some legal scholars contend that 
than in any other industry, the revenues that pharmaceutical companies earn from their patents appear to have a significant affect on their willingness to invest in R\&D. ${ }^{213}$ Although it is not certain that a longer patent term would motivate additional drug development, we have every reason to think it would have this effect. ${ }^{214}$ Indeed, there are certain types of drugs that firms will rarely develop because the 20 -year patent term is too short given the amount of time it takes to

pharmaceutical companies are largely insulated from the loss of revenue following generic entry because they manage to switch consumers onto related drugs that are still patented. See Hempill \& Lemley, supra note 211, 960-62. However, with insurers now using tiered formularies and other strategies to encourage the use of low-cost generics, these strategies are increasingly ineffective, and drug companies now lose most of their market to generic competition shortly after losing patent protection. See Murray Aitken et al., Prescription Drug Spending Trends in the United States: Looking Beyond the Turning Point, 28 Health AFFaIRS w151 (2008).

${ }^{213}$ Scholars have been unable to devise a reliable empirical test utilizing natural experiments to measure the effects of patent protection on pharmaceutical R\&D. However, there is a wealth of evidence from other sources that private sector drug $\mathrm{R} \& \mathrm{D}$ largely hinges on patent protection. First, given the costs of pharmaceutical $\mathrm{R} \& \mathrm{D}$ relative to imitation, it is doubtful that firms could sustain their current levels of $\mathrm{R} \& \mathrm{D}$ spending without legal barriers to imitation. According to the most recent figures, the average capitalized cost of bringing a new drug to market is approximately $\$ 1.2$ billion, including the costs of failed drug candidates. See DiMasi \& Grabowski, supra note 183, at $469 \& 475$. About half of those costs stem from drug discovery efforts and pre-clinical optimization and toxicology studies, while the other half is spent on the clinical trials necessary to satisfy the FDA's safety and efficacy standards. Id. (Contrary to some reports, these figures of the average R\&D costs for new drugs do not include marketing expenses.) Small-molecule drugs are relatively easy to copy once their active ingredient is made public, and generic manufacturers can rely on the brand name company's clinical trial data for regulatory approval. As a result, generic manufacturers enter the market at a tiny fraction of the innovator's costs - usually somewhere between $\$ 1$ and $\$ 5$ million per drug. See Federal Trade Commission, Emerging Health Care issues: Follow-on Biologic DRUG COMPETITION 14 (2009). The fact that drug companies are willing to spend billions of dollars on the R\&D of products that are so easy to imitate suggests that patents are critical for their business model. Second, the pharmaceutical industry is one of the few places where industry executives report that patents are essential to firms for recovering their R\&D investments. See Mansfield et al., supra note 3, at 915; Mansfield, supra note 39, at 175 n.8; C.T. TAylor \& Z. A. Silberston, The Economic Impact of the Patent System 199 (1973). Third, there is substantial evidence that pharmaceutical companies regularly refuse to develop new drugs when they cannot secure adequate patent protection over them. See Roin, supra note 22, at 545-56 (compiling reports from both within and outside of the pharmaceutical industry that firms routinely screen through the compounds in their pipeline to evaluate the strength of their intellectual property, and will usually halt the development of any drug found to have weak (or no) patent protection, almost regardless of its therapeutic or market potential); Cornelia Tilp, et al., Prerequisites for the Pharmaceutical Industry to Develop and Commercialize Helminths and Helminth-Derived Product Therapy, _ INT'L J. PARASITOLOGY _ (2013) ("Before a company will invest in developing a new drug, at least a rough reimbursement strategy should be in place. Patent protection is a mandatory prerequisite and if no patent exists it has to be clear that intellectually property (IP) can be established and protected."); Richard G. Zimmermann, Why are Investors Not Interested in My Radiotracer? The Industrial and Regulatory Constraints in the Development of Radiopharmaceuticals, — NuClear Medicine and Biology _ (2013) ("Attracting venture investment in a non-patented technology is next to impossible.").

214 See Dana P. Goldman et al., The Benefits from Giving Makers of Conventional 'Small Molecule' Drugs Longer Exclusivity Over Clinical Trial Data, 30 HeAlth AfFaiRs 84 (2011). There is ample evidence that pharmaceutical R\&D spending is sensitive to changes in reimbursement rates and other factors affecting the revenues generated by their drugs. See Margaret E. Blume-Kohout \& Neeraj Sood, Market Size and Innovation: Effects of Medicare Part D on Pharmaceutical Research and Development, 97 J. Public EcON. 327 (2013). 
complete their R\&D - including early-stage and preventative treatments for cancer ${ }^{215}$ and

Alzheimer's disease. ${ }^{216}$ On the other hand, high drug prices also put strain on the health care system and create consumer deadweight loss. ${ }^{217}$ According to one survey, roughly a quarter of Americans save money by not filling prescriptions, skipping doses or cutting their pills in half, and most of those people said that their medical condition got worse as a result. ${ }^{218}$ Not surprisingly, questions about the optimal patent length for drugs are contentious and opinions differ. ${ }^{219}$ Tailoring is the only way to avoid this painful tradeoff between access and innovation.

215 See Powel H. Brown, Chemoprevention Clinical Trials: It Is Time to Turn Success into Progress, 16 CANCER Epidemiology Biomarkers Prev. 531, 531-32 (2007); Rena Conti, Balancing Safety, Effectiveness, and Public Desire: The FDA and Cancer, Issue BRIEF \#615, 2, April 2003; Jennifer J. Griggs et al., Chapter 2: Successes and Satisfaction Factors in Oncology Career Paths, in Achieving Career SucGess in Oncology: A Practical Guide (Laura F. Hutchins ed. 2008); Ronald B. Herberman et al., Cancer Chemoprevention and Cancer Preventive Vaccines - A Call to Action: Leaders of Diverse Stakeholder Groups Present Strategies for Overcoming Multiple Barriers to Meet an Urgent Need, 66 CANCER RES. 11540 (2006); Frank L. Meyskens Jr. et al., Regulatory Approval of Cancer Risk-Reducing (Chemopreventive) Drugs: Moving What We Have Learned into the Clinic, 4 CANCER PREv. RES. 311 (2011); James L. Mulshine, Fostering Chemopreventive Agent Development: How to Proceed?, 22 J. Cellular Biochemistry (Suppl.) 254 (1995).

216 See Jeffrey L. Cummings, Controversies in Alzheimer's Disease Drug Development, 20 InT'L REV. PsyCHIATRY 389 (2008); Harald Hampel et al., Biomarkers for Alzheimer's Disease: Academic, Industry and Regulatory Perspectives, 9 NATURE REV. Drug Discovery 560, 568 (2010); Eric Karran et al., The Amyloid Cascade Hypothesis for Alzheimer's Disease: an Appraisal for the Development of Therapeutics, 10 NAture Rev: Drug Discovery 698, 709 box 3 (2011); Zaven S. Khachaturian et al., A Roadmap for the Prevention of Dementia: The Inaugural Leon Thal Symposium, 4 ALzHEIMERS DEmenT. 156 (2008); Tom Rooney, Head of Translational Research in the Neurodegeneratives Diseases Group at Sanofi S.A., Addressing the REDD Challenges, at Facing the Future: Developing an EU Strategy on Alzheimer's, Sept. 21, 2011, available at http://www.theparliament.com/fileadmin/theParliament/pdfs/ThomasRooney.pdf.

217 Some scholars estimate that drug patents generate anywhere from $\$ 5$ to $\$ 30$ billion of deadweight loss in the U.S. each year. See Aidan Hollis, An Efficient Reward System for Pharmaceutical Innovation 7-8 (2005), at http://econ.ucalgary.ca/fac-files/ah/drugprizes.pdf. But see Gautier Duflos \& Frank R. Lichtenberg, Does Competition Stimulate Drug Utilization? The Impact of Changes in Market Structure on US Drug Prices, Marketing and Utilization, 32 INT'L REV. L. \& ECON. 95, 107-08 (2012) (finding that gains to consumers from generic drug prices are offset by the reduction in the pharmaceutical company's marketing activities and clinical research (e.g., testing their drugs for new indications) following patent expiration); Henry Grabowski et al., Does Generic Entry Always Increase Consumer Welfare?, 67 FoOd \& Drug L.J. 373 (2012) (same); Darius Lakdawalla \& Tomas Philipson, Does Intellectual Property Restrict Output?'An Analysis of Pharmaceutical Markets, 55 J.L. \& ECON. 151, 178-79 (2012) (same). Prescription-drug insurance also probably avoids a large portion of the deadweight loss from drug patents, but not all of it. See Darius Lakdawalla \& Neeraj Sood, The Welfare Effects of Public Drug Insurance (2007), NBER Working Paper Series No. 13501, at http://www.nber.org/papers/w13501.

218 See Kaiser Public Opinion, Economic Problems Facing Families 3-4 (April 2008) at http://kff.org/kaiserpolls/upload/7773.pdf.

${ }^{219}$ Compare Goldman et al., supra note 214 (arguing that longer exclusivity periods would generate immense social welfare gains), with Aaron S. Kesselheim et al., Extensions of Intellectual Property Rights and Delayed Adoption of Generic Drugs: Effects on Medicaid Spending, 25 HEALTH AFFAIRs 1637 (2006) (questioning the gains from longer exclusivity periods relative to the social costs of higher drug prices). 
The relevance of imitation costs to the analysis suggests that the relationship between development time and optimal patent length is itself subject to field-specific considerations. In the pharmaceutical industry, for example, the impact of time-to-market on optimal patent length is probably quite pronounced with traditional small-molecule drugs, where the costs of entry for generics are largely invariant to the development time and costs of the original drug. ${ }^{220}$ For the newer large-molecule drugs ("biologics"), however, imitating firms usually must produce at least some clinical trial data to establish the safety and efficacy of their products, ${ }^{221}$ which means the imitators need to replicate some portion of the innovator's R\&D efforts. ${ }^{222}$ Optimal patent length for biologic drugs is still a function of their development time, since imitators shoulder only a fraction of the innovator's burden associated with longer time-to-markets, but it is a slightly weaker relationship relative to small-molecule drugs. ${ }^{223}$ If the government were to begin tailoring patent awards based on time-to-market, it might want to take into consideration the differences in imitation costs.

\section{Time-to-Market Strongly Correlates with the Predictors of Optimal Patent Length within Models of Sequential Innovation}

The argument thus far concerning the relationship between time-to-market and optimal patent length builds from the standard economic criteria for the amount of patent protection

\footnotetext{
220 See supra note 205.

221 See 42 U.S.C.A. § 262(k)(2) (2011); see also Steven Kozlowski et al., Developing the Nation's Biosimilars Program, 365 N. ENG. J. MED. 385 (2011) (explaining that the FDA needs to require some clinical trial evidence for biosimilar products because biologic drugs are so large and complex that it is not yet possible to verify that two of them are therapeutically equivalent simply by comparing their structure).

222 The Federal Trade Commission (FTG) predicts (perhaps implausibly) that because of the clinical-trial requirements imposed on biosimilars, innovators will retain between 70 and 90 percent of its market share following biosimilar entry, and prices will drop by only 10 to 30 percent. See FTC, supra note 200, at vi. Largely on these grounds, the FTC argues against a proposal - later adopted in the 2009 Affordable Health Care Act - to provide an automate 12 years of market exclusivity for new biologic drugs. Id. at 10-18, 23-24.

223 Compare FTC, supra note 200, at 10-18, 23-24 (arguing that biologics drugs do not require any additional legal protections against imitation because imitators must fund expensive clinical trials to enter the market).
} 
needed to call forth an invention. The more recent theoretical literature on cumulative innovation raises a different set of concerns for calibrating patent awards - the costs and benefits of awarding patent monopolies that will cover subsequent innovations. Much of the current controversy surrounding patents in the high-tech industries relates to these issues. At the most basic level, the patent system's tendency to stifle subsequent innovation is in large part a function of product life cycles in an industry. Shorter life cycles increase the need for patent licensing and diminish the importance of patent protection relative to first-mover advantages. Since the timeto-market for inventions in a field strongly correlates with product life cycle length, tailoring patent awards based on time-to-market could address many (and perhaps most) of the concerns about patents stifling subsequent innovation.

\section{Product Life Cycles and Optimal Patent Length in Models of Sequential Innovation}

One of the lesser-noted implications of sequential innovation models is that product life cycles are relevant to optimal patent length. ${ }^{224}$ Since newer technologies eventually render the older ones obsolete, inventions have a finite commercial lifespan - a "life cycle" that begins when an invention first enters the market, and ends when it exits due to lack of demand. For the firms that create and sell these inventions, the life cycle of their innovations establishes the window of opportunity for them to earn a profit from their R\&D investment. Broader patents that cover later improvements in the technology can extend that window by allowing patentees to control

224 The idea that there should be a shorter patent term in industries with rapid product turnover is fairly intuitive, and the argument dates back to at least the early 1940s. See Hamilton, supra note 7, at 157 ("Technology moves now with a speed once undreamed of - its swift march dictates a shortening of the life of a patent. Industries move at very different tempos - unlikeness suggests life spans accommodated to their distinctive requirements."). More recently, patent scholars have argued that the short product life cycles typical in software justify eliminating software patents or shortening their duration, often on the ground that the short life cycles allow firms to recoup their R\&D investments primarily through first-mover advantages. See BURK \& LEMLEY, supra note 22, at 96 (citing numerous examples of this argument). This section builds upon these insights by using the theoretical framework outlined in Section III to provide a more comprehensive account of the relationship between optimal patent length and product life cycles under conditions of sequential innovation. 
subsequent improvements to their invention, but may stifle those later innovations as a result. ${ }^{225}$ Models of sequential innovation indicate that longer patent terms are less desirable when (1) innovation is more "cumulative," (2) transaction costs are high, and (3) earlier innovations do not require a lengthy patent term. They also suggest that there is less to gain from longer patents when inventions become obsolete quickly. ${ }^{226}$ Shorter product life cycles are related to all four of these factors in ways that call for a shorter patent term, while longer life cycles have the opposite effect.

The pacing of sequential innovation is much faster in some industries than others. ${ }^{227}$ All inventions will eventually be replaced by newer technologies, but depending on the industry, that process is likely to take anywhere from a few months to two or more decades. ${ }^{228}$ In a survey from the Intellectual Property Owner's Association, roughly a quarter of respondents said that the product life cycles in their industries are typically shorter than the time it takes to get a patent. ${ }^{229}$ Short life cycles are probably most common in the high-tech industries. ${ }^{230}$ In other sectors, however, and particularly in the pharmaceutical industry, firms usually anticipate that their inventions will be on the market for decades before falling into disuse. ${ }^{231}$

225 See O’Donoghue et al., supra note 27.

226 See supra Section III.B., text accompanying notes 92-100.

227 See L. Kamran Bilir, Patent Laws, Product Lifecycle Lengths, and Multinational Activity, _ AM. ECON. REV. _(forthcoming); Christian Broda \& David E. Weinstein, Product Creation and Destruction: Evidence and Price Implications, 100 AM. ECON. REV. 691, 701 tbl.5 (2010).

228 See Francesca Cornelli \& Mark A. Schankerman, Patent Renewals and RED Incentives, 30 RANDJ. ECON. 197,197 (1999); Gideon Parchomovsky \& R. Polk Wagner, Patent Portfolios, 154 U. PenN. L. ReV. 1, $14-15$ (2005).

${ }^{229}$ See Cockburn \& Henderson, supra note 84, at C.8. The average pendency time at the PTO is between three and four years. See London Economici, Economic Study on PATent Backlogs And a System of Mutual ReGognition: Final Report to the IntelleGtual Property OfFice 57 (2010).

230 See FTG, supra note 1, at 45; Aaron Aboagye et al., Finding the Next \$100 Billion in Semiconductor Revenues, MaKINSEY ON SEMICONDUCTORS 5-6 (2012) ("Fully half of the [semiconductor] industry's revenue, for instance, is derived from products that are less than six months old," and "the semiconductor industry seems to exist in a state of permanent deflation, thanks to its rapid innovation cycles.").

231 See Henry Grabowski \& John Vernon, A New Look at the Returns and Risks to Pharmaceutical REDD, 36 MGMT. SCI. 804, 809 (1990) (estimating that a patented drug has a product life cycle of 25 years on average). 
Industries characterized by rapid product turnover may experience greater problems with patents suppressing subsequent innovation because the older patents are more likely to cover later technological advances. Innovation tends to be incremental when product life cycles are short. ${ }^{232}$ Since each follow-on generation of a technology is a "smallish step rather than a breakthrough," ${ }^{233}$ there is less technological space between those generations, and earlier patents frequently read onto one or more generations of future advances. The resulting burden on subsequent innovators is multiplied when they are commercializing products that encompass a numerous distinct patentable inventions - i.e., when the technology is "complex" as opposed to "discrete." 234 There appears to be much less overlap between older patents and follow-on innovations in fields with lengthy product life cycles, ${ }^{235}$ in part because there is more technological distance separating the generations, ${ }^{236}$ and in part because foundational patents will be closer to (or past) expiration by the time subsequent innovators need to license them. ${ }^{237} \mathrm{In}$ industries where new technologies quickly replace older ones, therefore, earlier patents are more likely to operate as a tax on later advances.

232 See G. Merle Crawford, The Hidden Costs of Accelerated Product Development, 9 J. ProduCt InNOVATION Mgmt. 188, 191 (1992); Fred Langerak, et al., Balancing Development Costs and Sales to Optimize the Development Time of Product Line Additions, 27 J. Product Innovation Mgmt. 336 (2010); B.A. Lukas \& A. Menon, New Product Quality: Intended and Unintended Consequences of New Product Development Speed, 57 J. BUS. RES. 1258 (2004).

${ }^{233}$ Cf. Steve Lohr, In the High-Tech Patent Wars, an Inventor's Lament, N.Y. TIMES, Oct. 15, 2012 ("Incrementalism is 99 percent of what corporate research and development does,' Mr. [Stephen] Perlman said, adding: 'Heavens, that is not to say it isn't vitally important. Where would we be without it.' ... 'The problem is that fundamental patents are lumped together with incremental patents. And, as the world is trying to mitigate the over-litigation of incremental patents and patent offices are buried under them, little guys like us are just being steamrolled over. And it's not accidental steamrolling." ").

234 See Cohen et al., supra note 1; Levin et al., supra note 1; Shapiro, supra note .

${ }^{235}$ Cf. FTC, supra note 1, chapter 3, at 2.

236 See infra text accompanying notes _-_ (arguing that longer product life cycles are associated with greater technological distance between each generations of a technology because they reflect a longer and more expensive R\&D cycle).

237 See Menell \& Scotchmer, supra note 70, at . 
In addition to increasing the amount of licensing required to commercialize subsequent innovations, short product life cycles will exacerbate the competitive costs of those transactions, since any negotiation delays will eat up a large portion of their invention's commercial lifespan. Industry surveys indicate that patent licensing tends to require unusually difficult and costly due diligence, and that the negotiations are much harder to bring to a close due to the complexity of the agreements and high stakes involved. ${ }^{238}$ Firms can attempt to design around these patents instead of licensing them, but this strategy adds time to R\&D. In industries with short product life cycles, anything that delays the time-to-market for a new invention can be extremely costly to firms, since it reduces their already narrow window of opportunity to earn a profit. ${ }^{239}$ Moreover, unless their rivals (including the patentee) are all subject to the same delays, these subsequent innovators may be at a substantial competitive disadvantage. ${ }^{240}$ Some of the industries with short product life cycles develop institutional responses to these transaction costs, including large patent pools and massive cross-licensing deals between large rivals. ${ }^{241}$ Many commentators believe that these tactics tend to worsen the problem, however, in part because new entrants may be priced out of the market unless they have access to a large pool of patents. ${ }^{242}$

The controversy surrounding software patents provides a stark example of how incremental innovation and short product life cycles can greatly exacerbate the patent system's

\footnotetext{
238 See Cockburn, supra note 89, at 6 \& 9.

239 See supra note 135.

240 See Necmi Karagozoglu \& Warren B. Brown, Time-Based Management of the New Product Development Process, 10 J. Product InNOvation MGMt. 204, 204 (1993); Langerak et al., supra note 135, at 339 ("Customers already exposed to existing brands are not likely to postpone their purchase decision just to wait for a new product to come to market (Ali, 2000), especially if competitors already have introduced similar extensions.").

241 See Mann, supra note 86, at 1006-09.

242 See, e.g. , JAFFE \& LERNER, supra note 25, at ;
} 
tendency to stifle subsequent innovation, perhaps overwhelming its beneficial effects. ${ }^{243}$ Most new inventions in software are incremental advances over existing technology, and programmers routinely build upon one another's code to create these improvements. ${ }^{244}$ While the industry's breakneck pace of innovation quickly renders many software patents obsolete, ${ }^{245}$ some of the patents issued are broad enough to read onto several future generations of incremental advances. ${ }^{246}$ Other firms must either license or design around these forward-reaching patents. ${ }^{247}$ The resulting delays and cost increases in R\&D have become painfully apparent to most people in the industry. There are reports that up to $80 \%$ of software engineers now believe patents are slowing down innovation in their field. ${ }^{248}$

The tax on subsequent innovation from earlier patents would be a necessary evil if it were essential to call forth those earlier inventions, but lengthy patent terms tend to be less important in industries with rapid product turnover. ${ }^{249}$ Critics of software patents raise this very argument

243 See Julie Samuels, Oracle v. Google Shows the Folly of U.S. Software Patent Law, WIRED, Apr. 23, 2012; David A. Wheeler, Eliminate Software Patents (2011), at http://www.dwheeler.com/essays/software-patents.html (containing links to numerous articles that are critical of software patents written by academics, venture capitalists, entrepreneurs and industry executives). Other flaws in the patent system appear to be exacerbating the innovation-inhibiting effects of software patents. Lapses in examination quality and overly lenient standards of patentability lead the PTO to issue patents on software inventions that the public would receive anyway, creating a tax on subsequent research without the corresponding benefit of motivating the earlier advances. See Burk \& Lemley, supra note 5; Rochelle Dreyfuss, Pathological Patenting: The PTO as Cause or Cure, 104 MiCH. L. REv. 1559 (2006); FTC, supra note 1; JAFFE \& LERNER, supra note 25. Ambiguous claim language in software patents injects uncertainty into an environment where any legal risks in an R\&D investment will diminish investors' tolerance for technological and commercial risk. See BESSEN \& MEURER, supra note 22; Menell \& Meurer, supra note 22.

244 See FTG, supra note 1, at 45.

245 See Mann, supra note 86, at 979.

246 See Mark A. Lemley, Patents and the Return of Functional Claiming 1-4 (2012) at http://www.stanford.edu/dept/law/ipsc/Paper\%20PDF/Lemley,\%20Mark\%20-\%20Paper.pdf; Note, Everlasting Software, 125 HARV. L. REV. 1454 (2012).

247 See Mann, supra note 86, at 978-79; Steven Z. Szczepanski, Appendix 8E-Y. Antitrust Enforcement and Intellectual Property Rights: Promoting Innovation and Competition (Dept. of Justice, F.T.C. 2007), Chapter 8E. Antitrust and Misuse

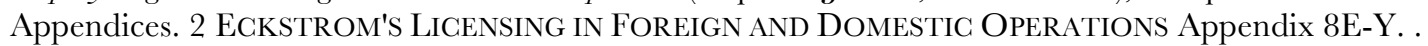

248 See Alex Blumberg \& Laura Sydell, When Patents Attack, This American Life, NPR, July 22, 2011, at http://www.npr.org/blogs/money/2011/07/26/138576167/when-patents-attack.

249 See Goldman, supra note 12; Bronwyn H. Hall \& Rosemarie Ham Ziedonis, The Patent Paradox Revisited: An Empirical Study of Patenting in the U.S. Semiconductor Industry, 1979-1995, 32 RAND J. ECON. 101 (2001); JAFFE \& 
to explain why a shorter (or no) patent term would be sufficient R\&D in that industry. ${ }^{250}$ The first-to-market usually has a head start in the race to produce the next generation of their invention, and in a field where product life cycles are short, rivals have much less time to catch up. ${ }^{251}$ Innovators can maintain (relatively) high profit margins by continually staying ahead of their rivals. ${ }^{252}$ An innovator's head start over its rivals is less significant in industries with extended product life cycles, which forces firms to rely on patent protection (or other barriers to imitation) to appropriate the returns to their R\&D. ${ }^{253}$

Longer patent terms have smaller beneficial effects on R\&D spending in industries with shorter life cycles not only because there are greater first-mover advantages in those fields, but also because most of their inventions become obsolete before their patents expire. ${ }^{254}$ As the author of a treatise on patent law (and practicing patent attorney) explains:

The term of available patent protection is more important in some industries than others. In the pharmaceutical industry, for example, where it takes many years for a product to reach the market, and where the same product, once introduced, can usually be sold for 20 years or more, it is vital to the patentee to obtain as long a patent term as possible. On the other hand, in an industry in which products can be brought to market quickly but are rapidly replaced by newer products, the

LERNER, supra note 25, at 57; Samuelson et al., supra note 24, at ; Ted Sichelman \& Stuart J.H. Graham, Patenting By Entrepreneurs: An Empirical Study, 17 Mich. Telecomm. Tech. L. Rev. 111, 137 (2010).

250 See, e.g., BuRK \& LEMLEY, supra note 22, at 96 ("Most commonly, scholars suggest that the rapid market cycles in software justify shorter terms of protection for software patents."); Menell, supra note 12; Mark Aaron Paley, Article: A Model Software Petite Patent Act, 12 Computer \& High Tech. L.J. 301, 306 (1996); Samuelson et al., supra note 24, at 2408; Michael Valek, Should Software Patents have Shorter Life Spans than Other Patents.?, CNET, Apr. 11, 2008 http://news.cnet.com/8301-13796_3-9917345-79.html (reporting that Federal Circuit Judge Pauline Newman suggested that a patent term of 5 to 6 years for software might make ore sense); Prepared Testimony and Statement for the Record of Jim Warren Before the Patent and Trademark Office (Jan. 26-27, 1994).

${ }^{251}$ See FTC, supra note 1, at ch 1, 35 n.224.

252 See Aghion et al., supra note 53, at 468.

${ }^{253}$ A recent study by Kamran Bilir tests this proposition by looking at which multinational firms are more likely to locate their manufacturing in countries with weaker IP protection, and finds that product life cycle length is one of the most important predictors. See Bilir, supra note 227.

254 See supra text accompanying notes 98-100; U.S. Pat. No. 7,949,581 "Method of determining an obsolescence rate of a technology," (May 24, 2011) ("The rate of patent obsolescence varies from technology to technology. Typically, faster-paced technologies, such as computer-electronics and software, decline more rapidly than slower-paced technologies, such as basic materials and simple mechanical technologies."). 
patentee is more interested in obtaining rapid grant of an enforceable patent than in prolonging patent term..$^{255}$

Although a small percentage of the patents issued in short life cycle industries will generate income throughout the patent term, the rapid pace of technological change in these industries suggests that much of these profits are a windfall. ${ }^{256}$ When firms are deciding whether to invest in an $\mathrm{R} \& \mathrm{D}$ project, they are probably much less likely to anticipate substantial patent royalties twenty years in the future when the technological landscape will be markedly different five or ten years out. Interestingly, it appears that in industries with short product life cycles (particularly the high-tech industry), most of the patent litigation that occurs toward the end of the patent term involves non-practicing entities that specialize in licensing ("patent trolls"), as opposed to manufacturing firms trying to protect their market. ${ }^{257}$

\section{Tailoring based on Time-to-Market as a Proxy for Product Life Cycles}

The relationship between optimal patent length and product life cycles outlined above suggests that the government might want to tailor patent awards based on the rate of product turnover in an industry. This additional layer of complexity is unnecessary. Product life cycles are closely correlated with the time-to-market for new inventions. Tailoring based on time-to-market

\footnotetext{
255 Philip W. Grubb, Patents for Chemicals, Pharmaceuticals and Biotechnology: Fundamentals of Global Law, Practice And Strategy 7 (4th $\mathrm{ed} .2004)$.

256 See JAFFE \& LERNER, supra note 25, at 57-58.

257 See Brian J. Love, An Empirical Study of Patent Litigation Timing: Could a Patent Term Reduction Decimate Trolls without Harming Innovators?, U. PENN. L. REV. (forthcoming). The social utility of the patent licensing and litigation practices of non-practicing entities that buy up older patents is the subject of debate. Id. Some of this behavior is almost certainly welfare reducing, however. There are growing reports of patent trolls using software patents of dubious validity to essentially "extort" money from more innovative companies by leveraging the high costs of patent litigation to extract modest licensing fees from numerous other firms. See Gene Quinn, Extortion Patent Style: Small Business in the Troll Crosshairs, IPWatchdog, May 24, 2011, at http://www.ipwatchdog.com/2011/05/24/extortionpatent-style-small-business-in-the-troll-crosshairs/id=17425/; Mike Lee, Software Patents are Legalized Extortion, ZDNet, Oct. 30, 2011, at http://www.zdnet.com/software-patents-are-legalised-extortion-3040094260/; Jonathan Potter, Remarks of Alliance President Fonathan Potter at the First USPTO Software Patent Roundtable, U.S. Patent and Trademark Office Software Patent Roundtable (2012), at http://appdevelopersalliance.org/news/2013-02-12-JPotterRemarks.
} 
should achieve roughly the same outcome, helping to avoid situations where longer patents will inhibit innovation while providing sufficient protection in areas where early innovators rely on those patent rights.

a. Time-to-market is strongly correlated with product life cycles. - The available data on product life cycles in various industries is much thinner than the data on time-to-market, but it is clear that the two are tightly correlated to one another. Evidence for this relationship mostly comes from industry surveys on the time-to-market of new products. Management scholars have been using surveys to acquire project-level data on R\&D times since the late 1980s, when scholars first began to argue that shortening the time-to-market was critical for firms to remain competitive. ${ }^{258}$ Within this survey literature, scholars have found that time-to-market "strongly correlates" with product life cycle length, both within and across firms. ${ }^{259}$

The reported product life cycle times in various industries also matches up well with the average development times in those industries relative to others. Cycle times appear to be shortest in the fields where new inventions reach the market quickly, such as consumer products, ${ }^{260}$ software, ${ }^{261}$ semiconductors (and computer hardware), ${ }^{262}$ which tend to be obsolete within a few years of entering the market. Although the inventions embodied in these products sometimes have a longer life cycle than the products themselves, estimates of patent life cycle

258 See Abbie Griffin, Legitimizing Academic Research in Design: Lessons from Research on New Product Development and Innovation, 28 J. Product InNovation MGMt. 428 (2011).

259 Griffin, supra note 134, at 297 (reviewing the literature and reporting results consistent with the claim); see also Eric H. Kessler \& Alok K. Chakrabarti, Innovation Speed: a Conceptual Model of Context, Antecedents, and Outcomes, 21 ACAD. MgMT. Rev. 1143 (1996).

260 See Broda \& Weinstein, supra note 227, at 701 tbl.5.

261 See Broda \& Weinstein, supra note 227, at 701 tbl.5 (finding that the product turnover rate for computer software was the third highest among the top 100 modules included in the consumer price index); FTC, supra note 1, at ch. 3, 45-46 (noting that with "innovation in the software and Internet industries," the "entire product life cycles sometimes pass before patents can be issued");

262 See Aaron Aboagye et al., Finding the Next $\$ 100$ Billion in Semiconductor Revenues, MCKINSEY ON SEMICONDUCTORS 5-6 (2012) ("Fully half of the [semiconductor] industry's revenue, for instance, is derived from products that are less than six months old."); FTC, supra note 1, at ch 1, 34-35 \& n.224. 
length in these industries (based on mean citation lag) confirm that they are some of the shortest. ${ }^{263}$ Meanwhile, it often takes 20 or more years for inventions to become obsolete in pharmaceuticals, ${ }^{264}$ oil \& gas exploration, ${ }^{265}$ and some clean-energy technology, ${ }^{266}$ where development cycles are longest. ${ }^{267}$ The relationship between development time and product life cycles also seems to hold for inventions within a given industry. In medical devices, for example, the life cycle for foundational patents on new-to-the-world devices can last well over a decade, while the cycle time for incremental improvements in those devices is roughly two years ${ }^{268}-$ corresponding well to the difference in their development times. ${ }^{269}$ Product life cycles are also much longer with fuel cells and solar technology relative to wind energy. ${ }^{270}$

At first glance, evidence of the relationship between development cycles and product life cycles is not particularly surprising. The reason most inventions become obsolete is that newer technologies entered the market to replace them. When it takes a long time for firms to develop and commercialize new inventions, the old ones should stay on the market for longer. This explanation for the relationship is incomplete, however. Firms could speed up the introduction of

263 See Bilir, supra note 227, at tbl.2 (finding that electronic machinery, computer and office equipment, and electronic components and accessories were ranked first, third and fifth respectively in shortest product lifecycle, as reflected by the mean patent-citation lag); FTC, supra note 1, at 45-46.

264 See Grabowski \& Vernon, supra note 231, at 809 (estimating that a patented drug has a product life cycle of 25 years on average).

265 See Neal, supra note 170, at 12 fg.IVF.1, 14.

266 See LEE ET AL., supra note 168, at 48.

267 See supra notes 165-170.

268 See Chris Rozewski \& Walter Thomson, Improving Manufacturability, Reducing Cost, and Extending Product Life - Processes and Pitfalls Unique to Medical Devices, at http://e-book.lib.sjtu.edu.cn/smat/Files/S6-4.pdf; THERESA WIZEMANN, ED., Public Health Effectiveness of the FDA 510(K) Clearance Process: Balancing Patient Safety and INNOVATION: WORKSHOP REPORT 20 (2010) ("The standard device product life cycle is 18-24 months; that is, a product is replaced by a new or improved product within 2 years. Such a fast life cycle occurs, however, only when the reimbursement and approval pathways have already been pioneered. It often is not until the third or fourth generation of a medical device that clinical significance and cost savings start to become apparent; this is because of the time needed for adoption of the technology.").

269 See supra notes and text accompanying notes 162-163.

270 See Bilir, supra note 227; RECHSTEINER, supra note 169, at 9. 
new inventions (thereby shortening product life cycles) by initiating new R\&D projects at a faster rate. If firms begin working on the next generation of a technology every two years, then they will be introducing those new products in a two-year cycle, even if each one of those inventions takes a long time to develop.

The reason that time-to-market is correlated with life cycle length ultimately is the same reason time-to-market is correlated with optimal patent length under the standard economic models. An extended time-to-market makes inventions far less profitable, all else equal, because it drives up $\mathrm{R} \& \mathrm{D}$ costs while diminishing the value of future revenue streams from the resulting inventions, and is associated with higher out-of-pocket R\&D expenses and greater uncertainty. ${ }^{271}$ Firms must compensate for these higher costs and risks relative to the reward by directing their $\mathrm{R} \& \mathrm{D}$ efforts to areas where consumer demand is stronger and there is less competition. This strategy usually involves developing inventions that will provide consumers with substantially more value relative to what is available from current technologies, since they need to be able to charge higher prices to support the necessary R\&D investment. Lengthy development cycles should therefore be associated with greater technological distance between sequential innovators. Moreover, because "new to the world" inventions take much longer to develop than incremental ones, ${ }^{272}$ the older technologies stay on the market for longer.

b. Sequential innovation and the benefits of tailoring based on time-to-market. - Tailoring patent awards based on development time should address many of the considerations relevant to optimal patent life within models of sequential innovation. To the extent that shorter times-tomarket result in faster product life cycles, they create an environment of overlapping patents and

\footnotetext{
271 See supra Section V.B.1.

272 See supra notes and text accompanying notes 196-198; Griffin, supra note 134, at 296 ("A number of researchers have hypothesized that higher innovativeness is associated with longer cycle times, and several have already found empirical support for this hypothesis."').
} 
increase the need for licensing, while also exacerbating the relative transaction costs of negotiating those agreements. ${ }^{273}$ At the same time, the shorter time-to-market increases the likelihood that a shorter (or no) patent term will be sufficient to motivate R\&D investments. Those inventions typically need less patent protection because they require less expensive and risky $\mathrm{R} \& \mathrm{D}$ investments relative to the future revenues they generate. ${ }^{274}$ They also need less protection because their shorter product life cycle increases the effectiveness of first-mover advantages as an appropriation strategy. ${ }^{275}$ Moreover, the shorter life cycles diminishes the likelihood that firms will spend more on R\&D in anticipation of future revenue streams 10 or 20 years later given the fast obsolescence rate and rapidly changing technological environment. 276 The recent study by Brian Love hints that shorter times-to-market will even correspond to the risk of "patent troll" litigation ${ }^{277}$ - and finds that most of that litigation occurs late in the patent term. ${ }^{278}$

The relationship between time-to-market and product life cycle length also suggests the patent term has the potential to be a much more effective policy lever than currently assumed. If there is a particular technological area where the patent system currently provides too little protection against imitation, lengthening the patent term is essentially pointless unless the life cycle of those inventions is longer than the current statutory term. Much of the recent literature on optimal patent length assumes that these situations are rare, since most inventions have a

\footnotetext{
273 See supra text accompanying notes 238-242.

274 See supra section V.B.1.

275 See supra text accompanying notes 249-253.

276 See supra text accompanying note 256.

277 See Love, supra note 257, tbl. 8 (reporting that non-practicing entity patent litigation is highest in relation to software patents, followed by "other high-tech," "medical devices," and finally "bio-pharma," where there is no nonpracticing entity litigation).

${ }^{278} I d$.
} 
relatively short life cycle. ${ }^{279}$ Given the strong correlation between optimal patent length and development time, ${ }^{280}$ this view underestimates the relevance of patent length as a means of spurring innovation. Inventions with long development cycles are more likely to need additional protection to motivate their $\mathrm{R} \& \mathrm{D}$, and because longer development cycles usually result in longer product life cycles, those same inventions are much more likely to be impacted by increasing the patent term. In short, as an invention's time-to-market increases and firms need stronger patent protection on average to recoup their $\mathrm{R} \& \mathrm{D}$ investment (relative to inventions with short development cycles), patent length becomes a more effective policy lever.

Models of sequential innovation greatly strengthen the case for tailoring patent awards based on time-to-market, but even without these insights, the observed variations in product life cycle length alone suggest that a tailored patent term is preferable. Providing the same duration of patent protection to inventions regardless of life cycle length is necessarily distortionary because it allows firms to appropriate a larger portion of their invention's social value if it has a shorter life cycle. When an invention becomes obsolete before its patent expires, the patentee appropriates a portion of that invention's value throughout its entire economic lifespan. Patents provide a more limited right of appropriation for inventions that remain in use beyond the statutory patent term. The patents on these inventions do not encompass their full economic lifespan, and the patentees therefore capture a smaller portion of the social value. This policy is particularly problematic given that life cycle length and development cycle are closely correlated. Inventions with a shorter time-to-market need less protection, not more.

\footnotetext{
279 See supra notes 98-100.

280 See supra section V.B.1.
} 


\section{Time-to-Market is Sufficiently Observable to Support a System of Tailored Patent Awards}

The core objection to tailoring patent awards is not based on a defense of the status quo, but rather on the inability to identify a principled and administrable system for the government to apply in determining which inventions need more protection than others. Many of the nation's most respected patent scholars have essentially given up hope on the prospect of a tailored patent system. ${ }^{281}$ Clarissa Long may have captured this sentiment best when she opined, "The same might be said of a unitary patent system that Winston Churchill famously said about democracy: It's the worst form of patent system, except for all the others that have been tried." $282 \mathrm{Or}$ as William Nordhaus concluded, "a fixed patent life is not optimal in theory, although it may be unavoidable in practice." ${ }^{283}$ The arguments outlined above suggests not only that it is possible to have a socially beneficial system of tailored patent awards, but that it would be much easier than anyone seems to have imagined. The optimal patent award for inventions strongly correlates with an easily observable feature - the time-to-market. With a reasonably designed system of tailored patent awards based on the average time-to-market for different technologies and industries, the government could greatly enhance the patent system's performance.

Time-to-market provides a simple, reliable, and transparent signal of optimal patent length that can be used to determine which types of inventions should receive more or less protection relative to one another and the current 20-year baseline. As shown in the previous sections of this paper, time-to-market correlates with most of the economic criteria affecting the optimal reward, thereby avoiding the need for a much more complicated and error-prone

\footnotetext{
281 See supra note 25.

282 See Long, supra note 4, at 49.

283 See Nordhaus, supra note 26, at 430.
} 
inquiry into the economics of innovation in each industry. ${ }^{284}$ There is also less room for favoritism in setting rewards when the tailoring is based on a single variable, especially if that variable is observable to the public.

In theory, the government could estimate the time-to-market for each patented invention to determine its award. Compared to almost all of the other economic factors relevant to optimal patent life, development time is a relatively observable characteristic, at least for most inventions. R\&D usually leaves a trail of documentation and work product that could be used to determine the project's start-date. ${ }^{285}$ Even simpler, the government could rely on the filing date on the inventor's patent as a rough proxy for the start of R\&D, since firms usually file their applications early in development. ${ }^{286}$ The date of commercialization is usually a public event, making it fairly easy to identify in most cases. Indeed, the patent system already inquires into this date when it applies the prior sale bar. ${ }^{287}$

Tailoring patent awards based on an estimate of the actual time-to-market for each invention would create several problems, however. It might allow firms to game the system by slowing down their R\&D projects to lengthen their patent term, ${ }^{288}$ or reward firms that sit on their patent rights for an extended period of time before developing the claimed invention. More

\footnotetext{
284 See supra text accompanying notes _-_.

285 The U.S.'s experience with interference hearings - where courts would determine which party was the first to conceive of a particular invention for purposes of establishing priority - suggests that this type of inquiry is manageable but costly. citation

286 See Robert Greene Sterne et al., The 2005 U.S. Patent Landscape for Electronic Companies, PRACTICING LAW Institute Patents, Copyrights, Trademarks, and Literary Property Course Handbook Series No. 5994, 295, 337 (2005).

287 See 35 U.S.C. $\S 102($ a) (2013).

288 Unless the government offered substantially greater patent awards for relatively minor delays, this type of gaming would probably be uncommon, since delaying the commercialization of a new invention by even a few months can have substantial competitive costs. See supra notes and text accompanying notes 134-138.
} 
importantly, the PTO receives over half a million patent applications each year. ${ }^{289}$ Trying to calculate the time-to-market for all of them would entail significant administrative costs.

Instead of tailoring patent awards based on the actual time-to-market of each new invention, the government could use the average time-to-market for that type of technology within the relevant industry. The average time-to-market in a particular field is relatively easy for the government to observe. Given private industry's "preoccupation" with getting their inventions to the market as quickly as possible, ${ }^{290}$ figures on the time-to-market for new products receive a lot of attention and tend to be widely known within industries. ${ }^{291}$ The government could put together a reasonably accurate estimate of the average time-to-market in different fields using publicly available information alone. The system would work better, however, if the government had accurate estimates of the average development times for the different categories of technology within each industry. To improve its estimates, the government could commission its own studies to acquire technology-specific averages within each field. Most firms already maintain careful records of the duration of their own R\&D projects for internal evaluation purposes, ${ }^{292}$ so the figures necessary for estimating the average time-to-market for most technologies will already exist. The government just needs to request them. ${ }^{293}$

Crucially, this system of tailoring patent awards based on time-to-market would allow the government to resolve the line-drawing questions that inevitably arise when implementing

289 See USPTO, supra note 99, at 175 tbl.1.

290 See Cooper, supra note 137.

291 See supra notes 151-171.

292 See Griffin, supra note 134.

293 Although it is conceivable that firms might try to deceive the government with fraudulent reports of the time-tomarket for their inventions, it is not likely to be a serious problem. The upside to this fraud would be small unless there are very few firms producing a particular type of technology, since any exaggerated (or deflated) figures submitted by one company would be watered down when the government computed the industry average. Moreover, fraudulent figures might look suspicious to the government when it has access to other firm's reported times-to-market, so the risk of detection might be high. If the government is still worried about fraud, it could use the threat of random audits to encourage truthful reporting. 
technology-specific rules. ${ }^{294}$ The boundaries between different fields of technology are inherently ambiguous and tend to shift over time. To successfully implement technology-specific rules, therefore, the government must be able to address any line-drawing questions through an administrable, policy-based analysis. The time-to-market for inventions is sufficiently observable that the government can use it to prevent firms from designing around the technology-specific rules by drafting their patent claims to select into advantageous categories. The government could adapt its rules quickly to account for significant changes in the average time-to-market in an industry. It could even create carve-out categories that will protect the inventions that take much longer to reach the market than the average invention in their class. For example, it might be beneficial to allow exemptions for breakthrough inventions, which often need more protection than the incremental advances in their field due to a longer time-to-market and greater risk of failure. ${ }^{295}$

The purpose of this paper is not to specify the exact details of how the government might tailor patent awards based on the time-to-market of inventions. The correlation between time-tomarket and optimal patent length provides the foundation for an administrable system of tailored patent awards, and the government could implement that system in a variety of different ways. Indeed, there are dozens of different policy levers that the government might use to tailor its patent awards based on time-to-market. While this paper focuses on the patent term, the government could also adjust the criteria for patentability, the breadth of patent rights, defenses to infringement, patent filing and maintenance fees, the stringency of PTO examinations, antitrust doctrines, and a host of other rules. The tailoring could even occur outside of the patent

\footnotetext{
294 See supra notes and text accompanying notes 127-133.

295 See supra notes and text accompanying notes 196-198.
} 
system through government subsidies or taxes, prizes, or regulatory barriers to entry. ${ }^{296}$ Decisions about how to tailor patent awards could be made by Congress, agencies, courts, or some combination of these actors. ${ }^{297}$ Although there is virtue in simplicity, the government's tailoring framework does not need to be based exclusively on time-to-market. If it has access to other relevant information that could be incorporated into a reliable framework for determining which inventions warrant greater protection than others, those factors can (and should) be considered. Variations in the time-to-market for inventions provide a solid foundation for tailoring patent awards, but the framework could be enriched when appropriate.

\section{Other Objections to Tailoring Patent Awards}

Patent scholars occasionally raise two additional objections to tailoring patent awards through technology-specific rules. The first is that any "discriminatory" treatment of inventions within patent law violates the TRIPS agreement, particularly if it involves a variable patent term. This argument is probably correct as a doctrinal matter, but it is not clear if other countries would want to enforce the TRIPS requirements against the U.S. in this context, and if they did, it is likely that there would not be any meaningful sanction for non-compliance. The second objection is that any attempt to craft technology-specific laws would lead to extensive lobbying by industry groups for special protections, ultimately producing a worse set of laws that the current

296 See Eisenberg, supra note 211, at 365 (discussing the use of FDA exclusivity periods to tailor the protection available to pharmaceutical companies against generic competition); Rai, supra note 22 (same); Roin, supra note 22 (same).

297 The majority of commentators remain wary of relying on Congress to draft industry-specific rules, usually on the grounds that the legislative process is slow and too vulnerable to manipulation through rent seeking. See, e.g., Arti K. Rai, Engaging Facts and Policy: A Multi-Institutional Approach to Patent System Reform, 103 CoLUM. L. REV. 1035,1128 (2003). However, a number of scholars now support using the courts or regulators craft rules that would tailor patent awards that account for the particular circumstances of each industry and field of technology. See Burk \& Lemley, supra note 5; Burstein, supra note 22; Johnson, supra note 22; Masur, supra note 22; cf. Arti K. Rai \& Rebecca S. Eisenberg, Bayh-Dole Reform and the Progress of Biomedicine, 66 LAw \& ConTEMP. PROBS. 289, 302-03 (2003). There have also been some discussions about whether particular industries should be allowed to craft their own technologyspecific patent laws. See Alan Devlin, Systemic Bias in Patent Law, 61 DePAUl L. REV. 57 (2011); Partnoy, supra note 22. 
uniform provisions. Although the concerns about rent seeking are legitimate, this argument greatly exaggerates the danger posed by any break with the current one-size-fits-all patent system.

\section{A. The TRIPS Objection}

The first objection lodged against proposals for a variable patent term or any technologyspecific patent law is usually that it would violate the TRIPS Agreement. ${ }^{298}$ Unless the technology-specific laws would cause economic injury to other countries by lowering their trade exports to the U.S., there might not be any sanction for this violation. TRIPS provides a reason not to shorten the patent term in areas where foreign firms unambiguously benefit from patent protection (e.g., in the pharmaceutical industry), but not elsewhere.

The TRIPS agreement requires WTO member nations to have a patent term of at least "twenty years counting from the filing date," ${ }^{299}$ and to ensure that patent rights are "enjoyable without discrimination as to ... the field of technology." 300 Scholars have debated whether countries can have technology-specific patent laws without crossing the line into "discrimination," 301 but no one has argued that countries can shorten the patent term for some inventions. 302 As Rochelle Dreyfuss and Graeme Dinwoodie explain, TRIPS "makes the

\footnotetext{
298 See BURK \& LEMLEY, supra note 22, at 97; Eisenberg, supra note 211, at 365; Long, supra note 4, at 49; Jerome H. Reichman \& Rochelle Cooper Dreyfuss, Harmonization without Consensus: Critical Reflections on Drafting a Substantive Patent Law Treaty, 57 DukE L.J. 85, $111-112$ (2007).

299 TRIPS, art. 33, 93-94.

$300 I d .$, art. $27(1)$.

301 See Graeme B. Dinwoodie \& Rochelle C. Dreyfuss, Diversifying Without Discriminating: Complying with the Mandates of the TRIPS Agreement, 13 Mich. Telecomm. TECH. L. REV. 445 (2007)

302 See, e.g., Colleen Chien, Tailoring the Patent System to Work for Software and Technology Patents, WIRED.COM, (forthcoming 2013) (arguing that the TRIPS antidiscrimination provision allows for much more flexibility than commonly assumed in adopting technology-specific patent laws, but not so far as to permit a variable patent term).
} 
required term crystal clear." 303 This argument helped stifle otherwise popular proposals to shorten the term of protection for software patents during the legislative debates leading up to the 2011 America Invents Act. ${ }^{304}$

This objection to technology-specific patent laws does not deserve the weight it has been given. TRIPS may carry the normative force of an international agreement, ${ }^{305}$ but it is not biding U.S. law, and the WTO mechanisms for inducing compliance are relatively weak. ${ }^{306}$ The only way to enforce the TRIPS requirements is through a WTO dispute resolution panel, and only member nations (not individuals) have standing to bring a complaint. ${ }^{307}$ Assuming that another country would want to challenge differential patent terms, it would take years for them to prosecute their case to an actionable ruling, ${ }^{308}$ and even then, the WTO cannot force the U.S. to change its laws or to pay damages to the injured nation. ${ }^{309}$ The only remedy would be the right to impose retaliatory sanctions against the U.S. ${ }^{310}$ The WTO has already ruled against the U.S.

\footnotetext{
${ }^{303}$ Dinwoodie \& Dreyfuss, supra note 303, at 454 n.39 (arguing that TRIPS provides (or should provide) much more for technology-specific laws than is commonly assumed, but "Members would not have complete discretion. For example, we doubt that they could curtail the term of a patent").

${ }^{304}$ See Chien, supra note 302 ("While this [antidiscrimination] clause hasn't attracted much attention, for years it has stymied popular proposals like abolishing software patents or putting a 5-year limit on them. 'Because it's illegal under TRIPS,' is a common refrain heard on Capitol Hill.").

305 See Abram Chayes \& Antonia Handler Chayes, The New Sovereignty: Compliance with INTERNATIONAL REGULATORY AGREEMENTS 116 (1995).

306 See Rachel Brewster, The Remedy Gap: Institutional Design, Retaliation, and Trade Law Enforcement, 80 GEO. L. Rev. 102 (2011) (arguing that that the sheer amount of time it takes for nations to secure a judgment and enforceable remedy before the WTO, combined with the absence of any damages for past injuries in that remedy, creates a substantial under-deterrence problem for WTO law).

307 TRIPS, supra, art. 64(1). For a discussion of the logic underlying these rules, see Alan O. Sykes, Public versus Private Enforcement of International Economic Law: Standing and Remedy, 34 J. LEGAL STUD. 631 (2005).

308 See Brewster, supra note 306.

309 See Alan O. Sykes, Trade Remedy Laws, in ReSEARch HANDbOOK IN InTERnATIONAL EGONOMIG LAw 62 (Andrew T. Guzman \& Alan O. Sykes eds. 2007).

310 See Brewster, supra note 306, at 109-110 (describing the available remedies for trade violations within the WTO);
} 
in two separate cases involving U.S. laws that allegedly violate TRIPS, and in both instances, the U.S. has refused to modify its non-compliant policy. ${ }^{311}$

The WTO remedies are particularly weak in this context, where Congress would be tailoring the patent system to promote $\mathrm{R} \& \mathrm{D}$ spending in private industry. Assuming that excessive patent grants are stifling innovation and reducing the returns from R\&D investments in certain fields, as many people believe, ${ }^{312}$ shortening the patent term for some (or all) of the inventions in those areas would probably increase industry profits. That policy would still violate TRIPS, but under the (somewhat ambiguous) WTO rules, it appears that any retaliatory sanctions would need to be tied to the complaining nation's overall loss in trade exports caused by the non-compliant policy. 313 There is no injury if foreign and domestic firms both benefit from new law. Indeed, foreign firms in the high-tech sector probably have the most to gain from a shorter patent term. They typically hold fewer U.S. patents than their domestic counterparts 314 ; they are less likely to enforce their U.S. patents in court ${ }^{315}$; and they tend to do poorly in patent

311 See Edward Lee, Measuring TRIPS Compliance and Defiance: The WTO Compliance Scorecard, 18 J. INTELL. PROP. L. 401, 411-12 (2011).

312 See, e.g., BESSEN \& MEURER, supra note 22, at (concluding based on litigation-event studies that patent enforcement overall has a negative effect on firm value in industries outside of pharmaceuticals and chemicals).

313 See supra note 310; Alan O. Sykes, Optimal Sanctions in the WTO: The Case for Decoupling (and the Uneasy Case for the Status Quo), Stanford Law and Economics Olin Working Paper No. 379. Available at SSRN: http://ssrn.com/abstract $=1444589$.

314 See James Bessen \& Rober M. Hunt, An Empirical Look at Software Patents, 16 J. EcON. \& MGMT. STRATEGY 157, 170 (2007); Bronwyn H. Hall, Exploring the Patent Explosion, 30 J. TECH. Transfer 35 (2005) (reporting that the "explosion" in U.S. patent rates during the 1980s and 90s was almost entirely due to an increase in patenting by U.S. firms in the high-tech sectors); Gaetan De Rassenfosse et al., The Worldwide Count of Priority Patents: A New Indicator of Inventive Activity, ECARES Working Paper 2012-019 (2012) (noting that "USPTO patent counts are strongly biased in favour of US and Canadian inventors, owing to the high propensity of North American applicants to file patents at that patent office").

315 See Kimberly A. Moore, Xenophobia in American Courts, 97 Nw. U. L. REv. 1497, 1504-05 (2003) ("Although foreign inventors acquire $45 \%$ of patent rights annually, they seek to enforce their patent rights in only $13 \%$ of the litigated cases."). 
cases tried to a jury. ${ }^{316}$ Under most circumstances, therefore, the TRIPS requirements should not stop Congress from tailoring patent awards for the purpose of promoting innovation. ${ }^{317}$

\section{B. The Political Economy Objection}

Another frequent objection to tailoring patent awards through technology-specific rules is that it would open up the floodgates to industry rent seeking. These concerns are legitimate, but they are less worrisome here than in most other areas of industrial policy, since there tends to be less distance between private industry's interests and the public interest in the context of patent reform. ${ }^{318}$ Most of the technology-specific patent laws on the books are thought to be beneficial, including the set of drug-patent provisions in the Hatch-Waxman Act, which (despite their flaws) are widely seen as a great triumph of public policy. The current 20-year term of protection and other untailored patent rules leave a lot of room for improvement, and the concerns about industry capture are not significant enough to give up on the hope of reform.

Several prominent patent scholars have warned that unless Congress remains committed to maintaining the unitary patent laws, the system will quickly devolve into a legislative tool for

\footnotetext{
316 See id. at 1504 ("Domestic parties win 64\% of cases tried to juries in which the adversary is foreign ... . However, there is no significant difference in win rates for foreign and domestic parties when judges adjudicate.").

317 TRIPS is more likely to be a problem for patent reforms that attempt to avoid excessive patent grants that harm U.S. consumers but increase industry profits, although it still might be difficult to establish an injury outside of the pharmaceutical industry. In theory, any policy that diminishes the length or strength of patents in a field to avoid unnecessary consumer deadweight loss (as opposed to facilitating subsequent innovation) should produce an observable loss in trade exports by the affected foreign firms. However, those effects will be complicated in industries where innovative companies are just as likely to be sued for patent infringement as to enforce their own patents, which includes most industries other than pharmaceuticals. If Congress were to selectively shorten the patent term for drugs, pharmaceutical companies would be unambiguously injured, and there would be a clear loss of revenue to foreign firm pharmaceutical companies earning royalties from U.S. drug sales. See supra notes and text accompanying notes 209-219; cf. Decision by the Arbitrators, Canada - Term of Patent Protection, WT/DS170/R (Sept. 18, 2000) (ruling in favor of the EU in a case it brought against Canada for violating TRIPS by providing less that 20 years of patent protection to pharmaceuticals). It is probably not a coincidence that every WTO trade ruling on patent policy thus far has involved a case brought on behalf of the pharmaceutical industry. See World Trade Organization (WTO), WTO Dispute Settlement: One-Page Case Summaries: 1995-2011, 24, 36, 47 \& 69 (2012).

318 See Gregory N. Mandel, Proxy Signals: Capturing Private Information for Public Benefit, 90 WASH. U.L. REV. 1, $36-37$ (2012). The pharmaceutical industry is an outlier in this regard. See infra note 323.
} 
dispensing favors to special-interest groups, and will begin to look more like the tax code or certain aspects of copyright law. ${ }^{319}$ Adam Jaffe and Josh Lerner argue that technology-specific laws are a slippery slope, and that special interest "shenanigans would be much worse in a world in which it was broadly accepted that differential patents for different technologies were appropriate." 320 Dan Burk and Mark Lemley contend that the unitary system shields patent law from distortionary rent seeking "because different industries have different interests, making it difficult for one interest group to push through changes to the statute."321 Clarissa Long echoes these concerns: 'patent law's 'uniformity norm,' which mandates that patent law should be technology-neutral, has been especially important in making the statute more impervious to interest group pressures than the copyright statute, which heavily bears the marks of interest group influence." 322

Although the skeptics of technology-specific patent laws are right to be wary of industry capture, certain aspects of the patent system make industry capture less of a concern here than in other contexts. Outside of the pharmaceutical industry, ${ }^{323}$ most firms view patents as a double-

\footnotetext{
319 See John R. Allison \& Mark A. Lemley, The Growing Complexity of the United States Patent System, 82 B.U.L. REV. 77, 143 n.160 (2002); BURK \& LEMLEY, supra note 22, at 100; JAFFE \& LERNER, supra note 25, at 204; Long, supra note 4, at 48 .
}

320 JAFFE \& LERNER, supra note 25, at 205; id. at 198 ("[W] hile theoretical arguments can be made in favor of 'tuning' the attributes of patent protection in different technologies, opening the door to such tuning is likely to quickly lead to special pleading that will not serve the public interest.").

321 BURK \& LEMLEY, supra note 22, at 100; see also Allison \& Lemley, supra note 319, at 143 n.160 ("One of the real problems with such industry-specific tailoring is that it gives rise to enormous opportunities for rent seeking.").

322 Clarisa Long, Interest Groups in Patent and Copyright, SEQuential Essays of The Columbia LaW SchoOL FACULTY 157-58 (2008). Copyright scholars have been very critical of the various industry-specific provisions in the copyright laws, and often argue that those provisions are largely the product of industry rent seeking. See Jessica D. Litman, Copyright Legislation and Technological Change, 68 OR. L. Rev. 275 (1989); Timothy Wu, Copyright's Communications Policy, 103 Mich. L. REV. 278 (2004).

323 The FDA's regulatory structure creates a sharp division between the pharmaceutical companies that benefit from patent protection on their drugs and the generic manufacturers harmed by that protection, which changes the political dynamic in the industry. Pharmaceutical companies will almost always want to lengthen and strengthen their patent protection as they apply to generic manufacturers, while generics want a shorter term than preferred by the brand-name firms. Since the pharmaceutical companies have more resources to lobby, this dynamic could distort the patent system in ways that favor the interests of pharmaceutical companies over the general public. On 
edged sword. They use the patent system to gain a competitive advantage over rival firms, but their rivals can do the same to them, and the transaction costs in licensing can make it difficult for firms to negotiate mutually beneficial arrangements. ${ }^{324}$ While the publishing and entertainment industries continually (and successfully) push to lengthen the copyright term, ${ }^{325}$ industry's preferences for the patent term are much less one-sided. ${ }^{326}$ Relying on industry groups to lobby for the socially optimal patent length in their field may be naïve, ${ }^{327}$ but there are signs that many of those groups would lobby for - or at least accept - something closer to the socially optimal length than the current 20-year period. ${ }^{328}$

Patent scholars sometimes argue that the uniform patent laws provide a bulwark against distortionary rent seeking by powerful industry groups. ${ }^{329}$ It is true that the patent system has proven unusually resistant to one-sided capture by special-interest groups, but nothing has "blocked" legislators from doing to patent law what they have done to the tax code and copyright

the other hand, the government's role as a provider (or subsidizer) of health insurance puts it in the position of paying for these drugs. To the extent that legislators would prefer to provide their constituents with the same level of prescription drug benefits while diverting money from those programs to other projects, they have an incentive to shorten the drug-patent term (or take other measures to reduce spending on patented drugs, such as pushing for lower prices).

324 See supra notes 86-84.

325 See supra note 322. When Congress first established the patent and copyright systems in 1790, they both had a 14year term. While the patent term has remained relatively stable, the copyright term has steadily increased, and now stands at life-of-the-author plus 70 years. See Edward C. Walterscheid, The Remarkable-and Irrational-Disparity Between the Patent Term and the Copyright Term, 83 J. PAT. \& TRADEMARK OfF. SOC'Y 233, 233 (2001).

326 See Mandel, supra note 318.

327 Some scholars argue (or assume) that private industry will usually push for patent rights that are longer and stronger the socially optimal level of protection. See, e.g., William M. LANDES \& RiCHARD A. PosnER, THE Political ECONOMY OF INTElleGtual PROPERTy LAW 15 (2004) (noting that "the public and private interests in effective regulation of the patent process may coincide" in some places, "[b] this is unlikely to be a general feature of intellectual property law, because of the persisting asymmetry with regard to the private benefits from recognizing versus denying intellectual property rights."). Others suggest that industry groups will often want weaker patent rights relative to the social optimum because patents provide a vehicle for innovative start-ups to enter the field. See F. Scott Kieff, Property Rights and Property Rules for Commercializing Inventions, 85 MinN. L. REV. 697, 747-48 (2001).

${ }^{328}$ Cf. Matt Richtel, Chairman of Amazon Urges Reduction of Patent Terms, New York TiMes, Mar. 11, 2000, C4 (reporting that Jeff Bezos, the founder and CEO of Amazon.com, publicly advocates reducing the patent term for software and business-method patents to three to five years).

329 See supra note 321. 
law. The uniform patent laws do not stop Congress from passing technology-specific patent laws; they are the result of Congress not passing those laws. The rent-seeking objection to technologyspecific rules rests on the assumption that Congress is ideologically committed to treating all firms equally within the patent system, and that any technology-specific rule would undermine that legislative norm. ${ }^{330}$ Legislators' willingness to tinker with the tax code and copyright laws, while leaving the patent system largely untouched for the past 200 years, suggests that something else is at play than a collective commitment against using complicated statutes to provide specialinterest favors. Whatever is causing the resistance to specialized patent legislation that would benefit particular firms or industry groups at the public's expense, the predominantly uniform patent laws could be a product or side effect of that resistance, but not the explanation for it.

There are a few technology-specific patent laws that are already on the books, and none seem to reflect the rent-seeking problems that scholars fear. There are rules against patents on tax strategies ${ }^{331}$ and human organisms; ${ }^{332}$ a bar on enforcing surgical-method patents against medical providers; ${ }^{333}$ and a (recently expanded) prior-user defense in infringement cases involving business-method patents. ${ }^{334}$ None of these laws were industry handouts, and they have

\footnotetext{
330 See JAFFE \& LERNER, supra note 25, at 204 ("By and large, the presumption today is that everyone gets the same patent treatment. Without this presumption, there would be tremendous pressure by industries to get features in 'their' patents that they found desirable. Of course, the arguments for these preferences would always be couched in public interest terms, but when an industry lobbyist starts talking about the public interest, we all know it is a good time to keep an eye on the consumer's wallet."); Long, supra note 322, at 157-58.

331 See America Invents Act of 2011, Sept. 16, 2011, Public Law 112-29, sec. 14, 125 Stat. 284. (2011).

332 See America Invents Act of 2011, sec. 33(a). This provision in the America Invents Act codified a prior legislative directive and PTO policy that prohibited the patenting of human organisms. See Robert W. Bahr, PTO Memorandum, Claims Directed to or Encompassing a Human Organism, Sept. 20, 2011, at http://www.uspto.gov/aia_implementation/human-organism-memo.pdf.

33335 U.S.C. $§ 287$. This provision was strongly supported by the American Medical Association, and opposed by the pharmaceutical and biotechnology industries. See Craig Allen Nard, Legal Forms and the Common Law of Patents, 90 B.U. L. REV. 51, 102 n.269 (2010),

33435 U.S.C. § 273(a)(3) (added Nov. 29, 1999, Public Law 106-113, sec. 1000(a)(9), 113 Stat. 1501A-555 (S. 1948 sec. 4302). Congress amended this provision in 2011 to remove the business-method limitation. See America Invents Act of 2011, sec. 5 .
} 
not led to a flood of subsequent industry lobbying for firm-specific patent extensions or other rent-seeking distortions. ${ }^{335}$

The drug-specific patent provisions in the Hatch-Waxman Act of 1984 provide a compelling counterexample to the claim that technology-specific patent laws will inevitably benefit private industry at the public's expense. Hatch-Waxman established a regulatory pathway for generic drugs to enter the market without extensive clinical trials. ${ }^{336}$ To facilitate generic entry without shortening the effective patent life of new drugs (i.e., time from market launch to generic entry), Congress had to implement several counterbalancing drug-specific patent rules. ${ }^{337}$ It provided generic manufacturers with an experimental-use defense so they could enter the market faster, ${ }^{338}$ and created a bounty system to encourage challenges to drug patents. ${ }^{339}$ It then provided patent-term extensions to drug companies to compensate them for lost patent life, ${ }^{340}$ and created an automatic 30-month stay on generic entry while courts resolve patent disputes. ${ }^{341}$ Although the litigation between generics and drug companies has been problematic, ${ }^{342}$ most

\footnotetext{
335 Adam Jaffe and Josh Lerner cite two instances of drug-company lobbying as evidence that "Congress opened the door for such gaming when it passed the Hatch-Waxman Act.” JAFFE \& LERNER, supra note 25, at 204-05. They first point to a multi-million dollar lobbying effort by Schering-Plough to receive a three-year extension on the patent for Claritin $^{\mathrm{TM}}$, id. at 205, even though that effort failed and the drug went generic on schedule. See Gardiner Harris, As Blockbuster Claritin Goes Generic, Schering-Plough Pushes a Close Sibling, WALL. ST. J., Mar. 22, 2002. Their second example is a 2002 law that shielded Eli Lilly from product liability suits over one of their vaccines, but this provision is unrelated to the Hatch-Waxman Act and patent system. See JAFFE \& LERNER, supra note 25, at 205.

336 See Drug Price Competition and Patent Term Restoration Act of 1984 ("Hatch-Waxman Act"), Pub. L. No. 98417, 98 Stat. 1585 (1984) (codified as amended 21 U.S.C. $\$ 355$ (1994)).

337 See F.M. Scherer, The Political Economy of Patent Policy Reform in the United States, 7 J. TeLECOMM. \& HiGH TECH. L. 167, 197-98 (2009) (recounting the legislative history and compromises leading to the Hatch-Waxman Act).

33835 U.S.C. $\S 271(\mathrm{e})$.

33921 U.S.C. $§ 355(\mathrm{j})(5)(\mathrm{B})(\mathrm{iv})$.

34035 U.S.C. $\S 156$.

34121 U.S.C. $\S 355(\mathrm{j})(5)(\mathrm{B})(\mathrm{iii})$.

342 See Hemphill \& Lemley, supra note 211, at 948 (discussing some of the questionable strategies that pharmaceutical companies sometimes use to delay generic entry beyond the point at which their primary drug patents have expired); Roin, supra note 22, at (discussing how pharmaceutical companies screen many potentially valuable drugs out of their pipeline because their patents would be too weak to survive a challenge by generic manufacturers).
} 
commentators view the pairing of these rules as fair, ${ }^{343}$ and the statute overall is widely seen as a success story. ${ }^{344}$ The average effective patent life for new drugs has held steady at roughly 11 to 12 years. ${ }^{345}$ Meanwhile, the market share for generic drugs has gradually increased from 19\% of prescriptions filled in 1984 to $78 \%$ in 2011 , and is expected to keep growing - saving the U.S. health care system over $\$ 1$ trillion by one estimate. ${ }^{346}$ Skeptics of technology-specific patent laws still suggest that Hatch-Waxman illustrates the dangers of breaking with the uniform patent scheme, ${ }^{347}$ but the examples given tend to focus on the smaller issues, such as unseemly litigation tactics sometimes used in drug-patent litigation. ${ }^{348}$ No one argues that Hatch-Waxman is perfect. ${ }^{349}$ The question is whether it benefited the public relative to the uniform patent laws, or

${ }^{343}$ See Duffy, supra note 54, at 507 \& n.194; Arti K. Rai, The Information Revolution Reaches Pharmaceuticals: Balancing Innovation Incentives, Cost, and Access in the Post-Genomics Era, 2001 U. ILL. L. REv. 173, 182-83 (2001); Scherer, supra note 337, at 198.

${ }^{344}$ See Richard G. Frank, The Ongoing Regulation of Generic Drugs, 357 N. ENG. J. MED. 1993, 1993 (2007) (noting that Hatch-Waxman "is widely viewed as a health policy success story"). Indeed, the Hatch-Waxman Act usually receives its strongest praise from the commentators who tend to be highly critical of the pharmaceutical industry. See, e.g., Alfred B. Engelberg et al., Balancing Innovation, Access, and Profits - Market Exclusivity for Biologics, 361 N. ENG. J. MED. 1917 (2009) ("[T] he Waxman-Hatch Act successfully balanced the public interest in providing adequate incentives for investment in innovation with the public interest in providing affordable medications.").

345 See Grabowski \& Kyle, supra note 210, at 6 fg. 4; Hemphill \& Sampat, supra note 210. Estimating the average market exclusivity period for drugs prior to the Hatch-Waxman Act is difficult because generic drugs as we known them did not exist. Since there were no patent-term extensions to compensate firms for the patent life lost during clinical trials, their average effective patent life was roughly 9 years, but generics could not enter the market without completing their own round of clinical trials, and they could not begin testing until the drug patent expired. See Henry G. Grabowski \& John M. Vernon, Effective Patent Life in Pharmaceuticals, 19 InT’LJ. Tech. MgmT. 98, 103-04 (2000).

346 See United States Government Accountability Office (GAO), Drug Pricing: Research on Savings FROM GENERIC DRUG USE, 2 \& 4, GAO-12-371R (2012).

347 See BURK \& LEMLEY, supra note 22, at 100; Long, supra note 322, at 157 ("Although the patent community certainly doesn't lack for interest groups, they've made little headway in grabbing goodies for themselves, with only one significant exception - the Hatch-Waxman Act."); supra note 335 (discussing Jaffe and Lerner's contention that "Congress opened the door for such gaming when it passed the Hatch-Waxman Act").

348 See BURK \& LEMLEY, supra note 22, at 100 ("Nor should it be surprising that these industry-specific statutes have had some pernicious consequences - for example, the pharmaceutical-specific Hatch-Waxman provisions have been gamed on numerous occasions as pharmaceutical patent owners have manipulated the stay provisions or colluded with putative generic entrants to prevent entry into the market.”).

349 See, e.g., Frank, supra note 344, at 1995-96. 
instead benefited private industry at the public's expense, as the political-economy critique of technology-specific rules would predict. Hatch-Waxman is clearly an example of the former. ${ }^{350}$

Political economy concerns are always difficult to resolve, especially when framed around unspecified policy reforms. In this particular context, however, those concerns are not significant enough to reject proposals for tailoring patent awards based on objective criteria that are strongly correlated with the socially optimal reward.

\section{Gonclusion}

The primary justification for the uniform patent laws and fixed 20-year patent term is that the government does not have a reliable framework for determining which inventions should receive more protection than others. This paper provides that framework by showing that the optimal patent length for inventions is closely related to their time-to-market - an observable characteristic. The current policy of providing the same statutory term of protection and applying the same patent rules to all inventions, regardless of the amount of time it takes to develop them, visibly and predictably deviates from the optimum. The government should use differences in the average time-to-market for inventions as the foundation for a system of tailored patent awards.

350 Congress passed a law similar to Hatch-Waxman in 2010 to allow "follow-on" competition in the market for biologic drugs. See Title VII, Subtitle A, §§ 7001-7003, The Biologics Price Competition and Innovation Act of 2009 (BPCIA), of The Patient Protection and Affordable Care Act, Public Law 111-148, 124 Stat. 118 , 804 (111th Congress) (2010). The effects of this law are not yet known, but the legislative history makes clear that the major stakeholders vetted all of the bill's regulatory and patent provisions, and that the final legislation was a compromise between competing interests. See Krista Hessler Carver et al., An Unofficial Legislative History of the Biologics Price Competition and Innovation Act of 2009, 65 FOOD \& DRUG L.J. 671 (2010). 